Historic, Archive Document

Do not assume content reflects current scientific knowledge, policies, or practices. 

1. Inderea March 25:190b-

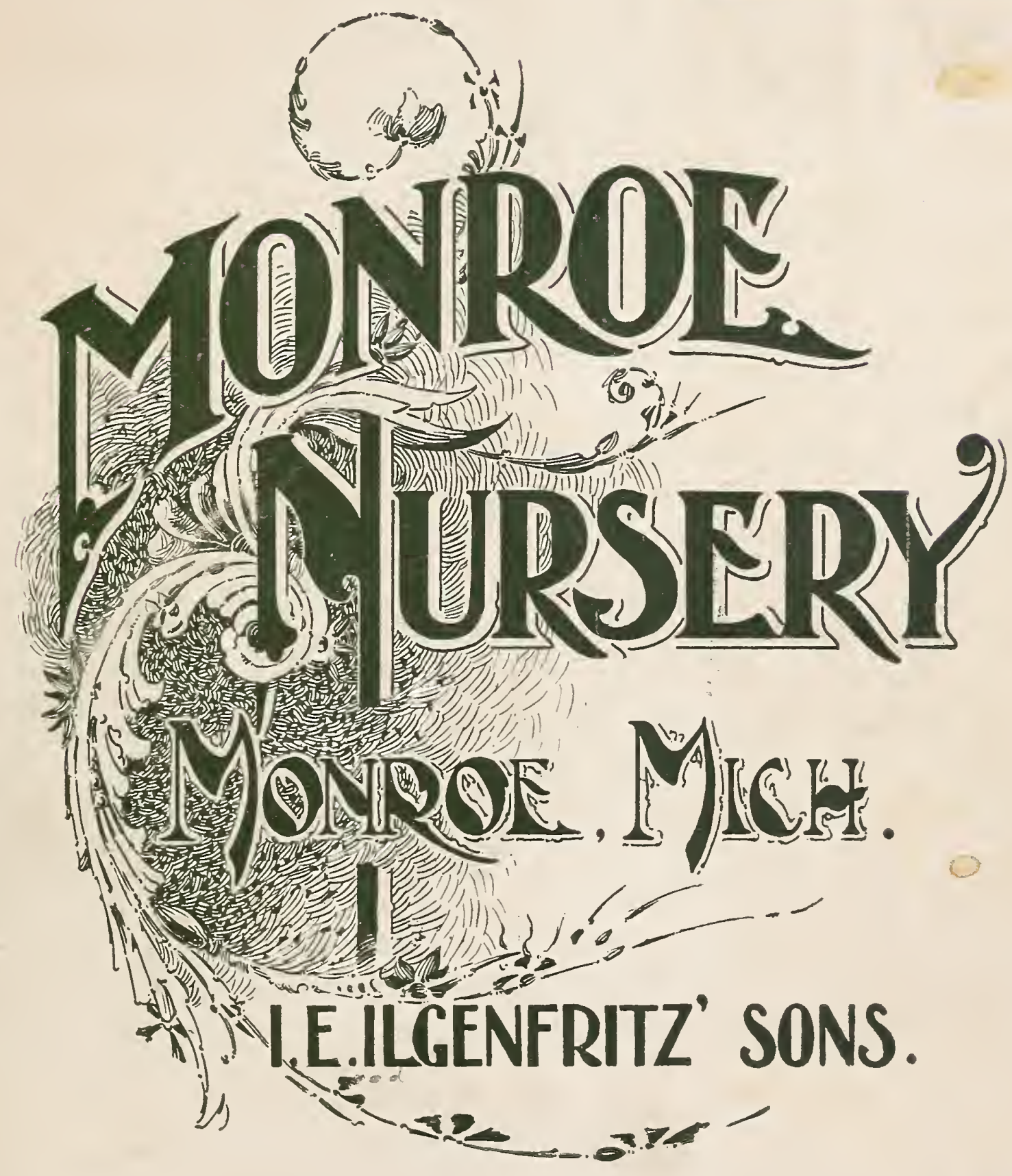




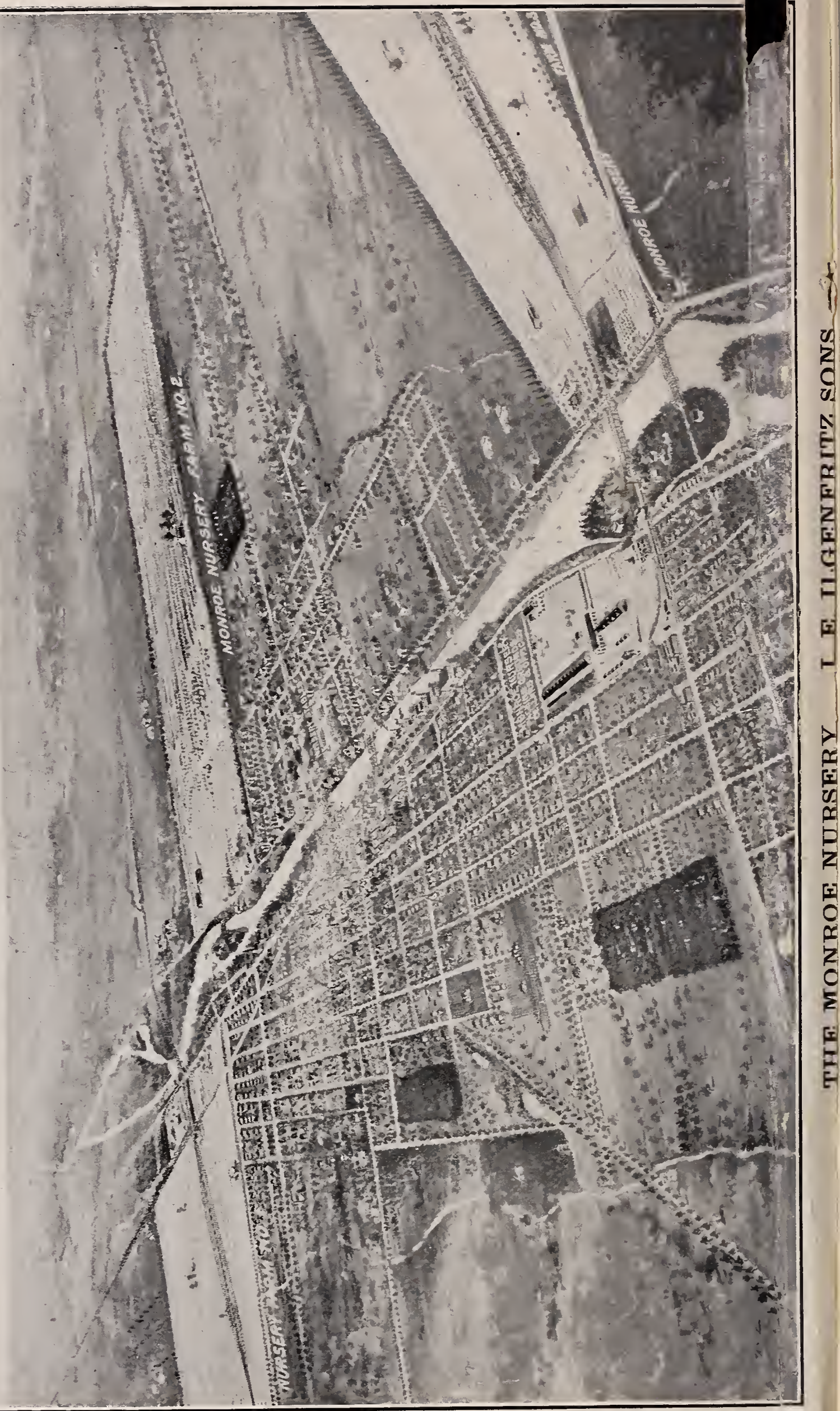




\section{ILLUSTRATED DESCRIPTIVE CATALOGUE}

. OF . .

\section{FRUTT TREES AND SHALL FRUITS,}

GRAPE-VINES, ESCULENT VINES,

\section{ORIAIIENTAL TREES, SHRUBS, VINES, ETC.,}

CULTIYATED AND FOR SALE BY

\section{E. ILGENFRITZ' SONS,}

MONROE NURSERY,

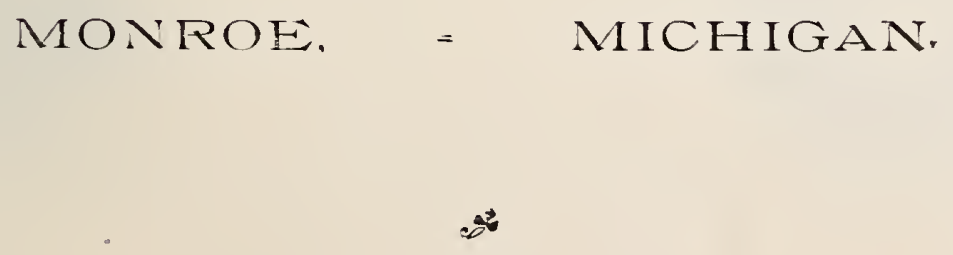



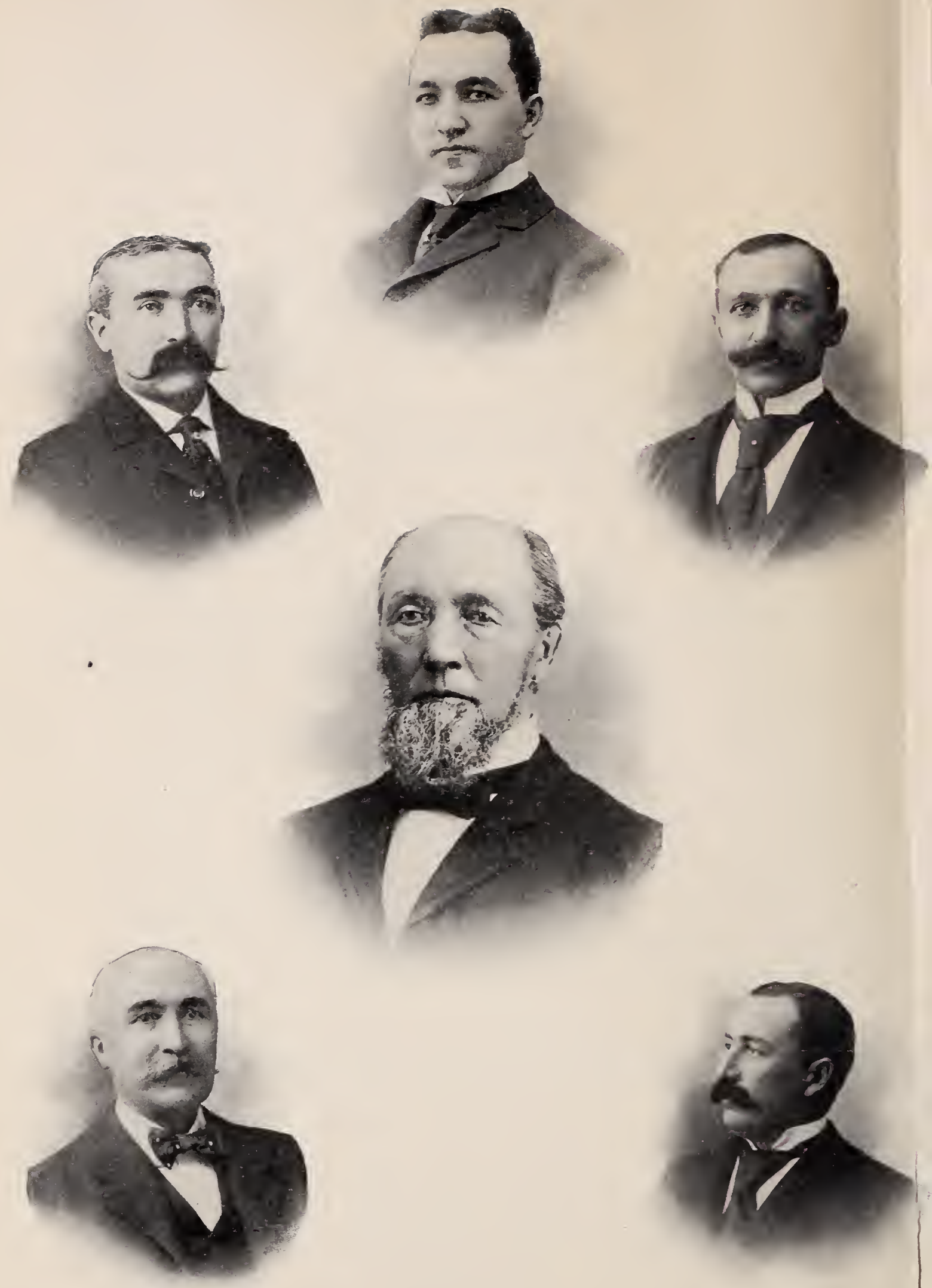

I. E. ILGENFRITZ' SONS. 


\section{INTRODUCTION.}

Haring passed our semi-centennial, we take pleasure in placing before you a supplementary catalogue, in which it is our desire to give a brief history of the Monroe Nursery and a tew illustrations rom photugraphs taken during the past season.

In $S_{47}$, I. E. Ilgenfritz, a young nuseryman, lett his holle in Pennsylvania asu with a small stock of embryo trees wended his way, by the then rude mode of traveling, into t:a west. He was in search of a suitable place at which he might stop, plant his trees and grow up with the country.

Upon reaching Monroe, which was at that time the terminus of the Lake Erie line of steamers, he found a place of much promise, and where the land was of. great variety and adapted to the different kinds of trees and plants. It consisted largely of a rich allurium underlaid with clay. covering the limestone formation but a few feet below the surface a land of flowers, and where upon the banks of the River Raisin the wild grape flourished. He saw at once that if sound, healthy trees could be grown anywhere, they could be grown upon such soil, and where the air is tempered with the lake winds.

So it was at this place that he decided to cast his lot. Procuring a small patch of ground he planted his young trees. carefully tended them and watched then grou-1hey thrived. The demand for such trees as these, well grown, carefully trimmed and cared for. soon over-taxed the small piece of ground, and more land was secured and planted to trees. And so it was from the beginning to the present, a series of successes. until to-day the Monroe Nursery comprises over six hundred acres of the most fertile soil of the State.

Our offices and packing grounds are second to none in the country. They are located adjoining the L. S. \& M. S. depot, with which we are connected by our own side track, and two blocks west of the M. C. depot, which makes our shipping facilities unsurpassed. On these grounds are located our immense storage cellars, which are the largest and finest in the United States. We were the originators of the storage cellar system and to-day we have the largest nursery storage cellar in the world.

Great care is exercised in raising the many different varieties of trees and plants, and it has always been our rule to advise our customers to plant only varieties of merit, and it is our aim in this supplementary catalogue to place only such varieties before you.

Dr. John A. Warder in his excellent work on apples, savs: "Every orchard planter who examines the extended varieties of fruits presented to him in the books and by the nurserymen, must feel greatly embarrassed when he comes to select the varieties for hi: own orchard. Almost every one in the long lists is recommended for some good quality, and the number of best which he is apt to conclude is indispensable to him, is wonderfully large. Some persons are bewildered by the array presented in the catalogue, and fall back upon their own slender stock of information, selecting only one well known variety; but most persons commit a far greater fault by attempting to grasp all the varieties that are offered and commended."

Our descriptive list herein given embraces many of the best and most of the popular varieties known, and although a complete list of those given might run into toc great a variety for profit, yet a well-selected assortment taken from the varieties given should be a most profitable one for any planter. While we take the greatest pains to have all of our 11 ursery stock true to label, and hold ourselves in readiness upon proper proof to replace all stock that may prove untrue, or refund the amount paid, it is mutually agreed between the purchaser and ourselves that we shall not be liable for any sum greater than that originally received for said stock direct from planter.

In the future, as in the past, it shall be our aim to retain for this establishment the good character it now enjoys, and those favoring us with their orders, either given to our agents or sent us directly by mail, will receive prompt and careful attention.

I. E. ILGENFRITZ' SONS.

Morme Mich. 


\section{TO CORRESPONDENTS.}

Orders by letter are promptly attended to, and we exercise great care in all cases to fill them exactly and satisfactorily.

Plain and explicit shipping dirzetions should be given. When none are given we forward according to our best judgment.

Orders should be sent in as early as possible in the season, that we may reserve such varieties as may be required, and also that they may be in time for shipping long distances.

Persons not conversant with the character of the different varieties may find it to their interest to leave the selection of sorts to our discretion, merely giving the number of trees wanted, and if they think proper, the proportion of summer, fall and winter varieties, in which case we shall feel it our duty to make a proper. selection. When selection is made by the purchaser, we shall give him the benefit of his choice so far as we can: but it sometimes happens that certain varieties are run upon and become exhausted, and when this occurs, we usually substitute other varieties of about the same season of ripening, unless expressly requested not to do so.

The packing is done in the most thorough manner, with moss and moist straw, in boxes and bales, so as to prevent injury from shipping long distances.

Packages will be delivered into the hands of the forwarders without extra charge, after which our responsibility for the safe transportation of the goods ceases, except on orders received through our agents.

Orders from unknown parties must be accompanied with the money or satisfactory references to insure attention.

We will cheerfully rectify any of our own mistakes if customers will promptly inform us of such.

Catalogues furnished free on application. 


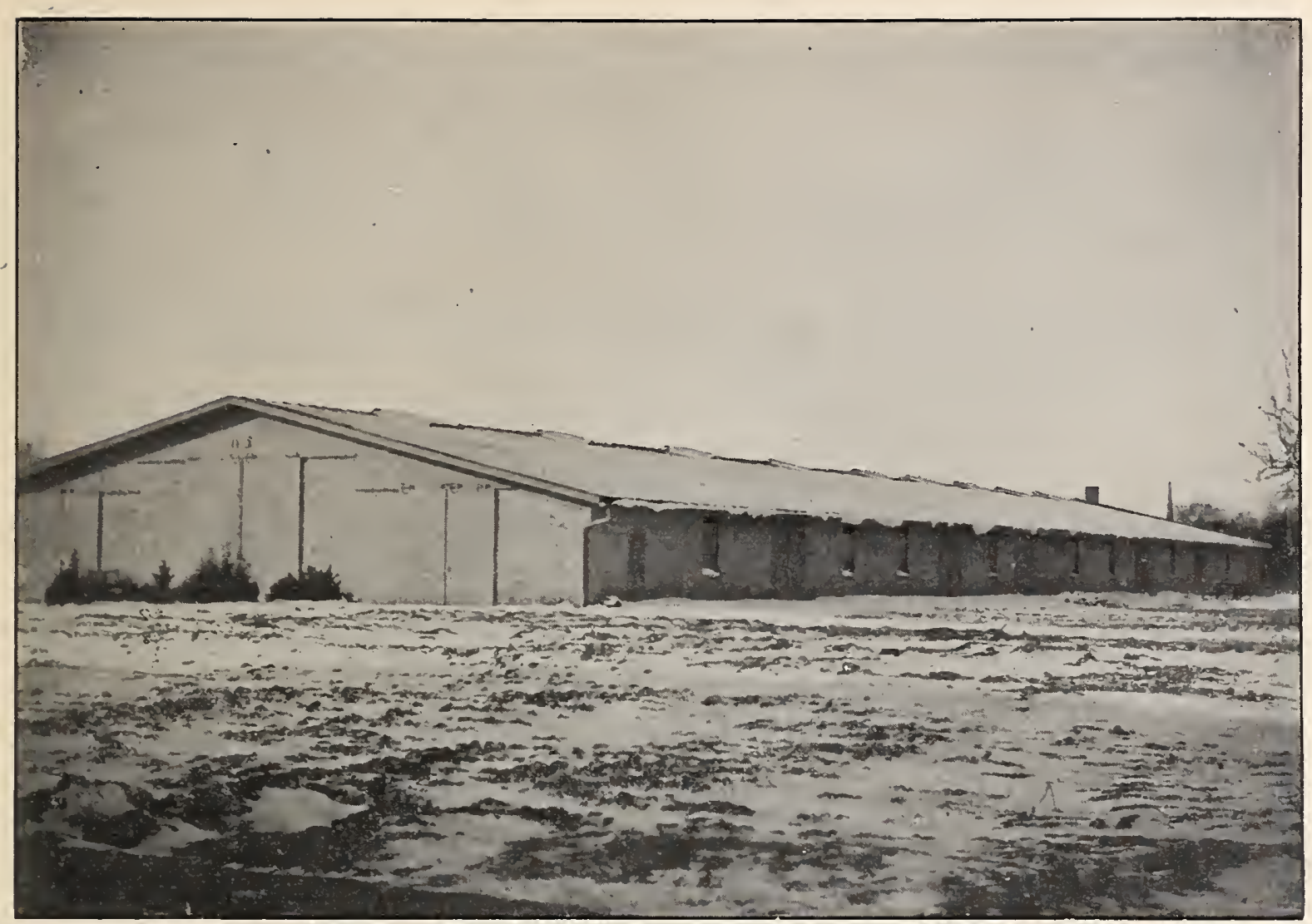

EXTERIOR OF THE LARGEST NURSERY CELLAR IN THE WORLD. Cellar No. 5 .

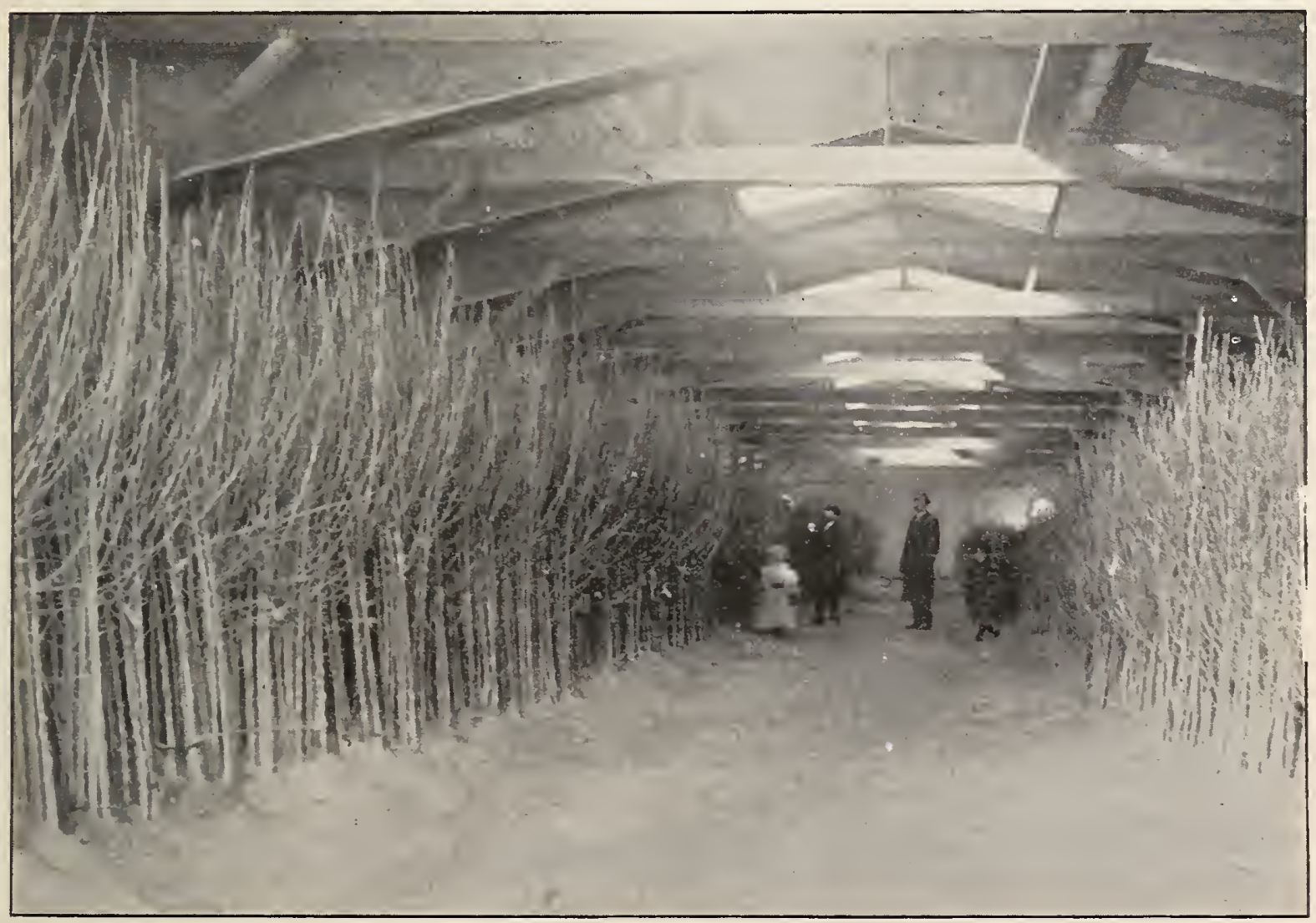

INTERIOR OF THE LARGEST NURSERY CELLAR IN THF WORLD. Cellar No. 5 . 


\section{Directions for Transplanting, Etc.}

As THE life and well-being of a tree depend very much upon the care and treatment it receives after it leaves the hands of the Nurseryman, and as a large proportion of the trees that are lost are lost for the want of proper treatment, we desire to offer a few hints upon the subject of transplanting, pruning, ctc.

\section{PREPARING THE SOIL.}

THE first important requisite to the successful raising of an orchard, is the proper preparation of the soil. This should be made $d r y$ and rich. Underdrained if necessary, as trees will not thrive in soil constantly saturated with stagnant moisture. It should be well plowed and, if possible, the sub-soil plow should be employed. It should be well manured - as well as for a crop of wheat or corn.

\section{PREPARING THE TREES FOR PLANTING.}

PRUNE carefully the bruised or broken parts of the roots with a sharp knife, sloping them off in such a way that the face of the cut will be down when the tree is in an upright position. This pruning of the roots must be followed by a pruning of the top, so as to keep the balance that formerly existed between the roots and the branches.

Prune the top by cutting back the branches of the previous season's growth about onehalf, exactly at a bud. This will be no loss eventually to the tree; on the contrary, the remaining buds will push out with extraordinary vigor. In pruning dwarf and pyramid trees, one and two years old, one-half of the current year's growth should be cut back, leaving the branches near the ground the longest, and gradually shorten them till the top is reached.

\section{PLANTING THE TREES.}

IF THE soil has been prepared as above directed, a lole dug large enough to admit the roots in their natural position is sufficient. If persons are obliged to plant on new or sod land, holes from four to six feet in diameter, and not less than twenty inches deep should be dug. Then partly fill the hole with good mellow earth; then one person should hold the tree in an upright position, while another person shovels in the finest and best earth among the roots, endeavoring to bring every root in contact with the soil, and not allow ing any sod or manure next to them. When the earth is nearly all filled in, pour in a pail of water, allowing it to settle away, and then fill in the remainder and tread gently with the foot. In planting on low ground it will be best to place the tree on top of the ground and heap the earth about it.

Trees should not be planted any deeper than they stood in the nursery. The roots should never be more than two or three inches below the surface. Every tree should be staked on the southwest side with a broad stake to prevent injury by the sun and winds. and tied so as to avoid chafing, by putting a piece of cloth between the tree and the stake.

\section{MULCHING.}

MULCHING is of great benefit to newly planted trees, especially if the ground be not cultivated, as it keeps the ground moist during the heat of summer. Coarse manure or partially decayed straw or leaves are very good material, which should be placed on the surface, three or four inches deep, and three or four feet around the tree, etc.

\section{AFTER CULTURE.}

For several years the ground should be well cultivated. Corn is one of the best crops to cultivate in a newly planted orchard. Trees derive nuch benefit from being washed : the spring with strong soapsuds. 


\section{WHEN RECEIVED IN THE FALL.}

TREES received in the fall should be "heeled in " (that is, a trench dug in a dry place, the trees laid in slanting, and well covered two-thirds up with clean soil,) and then planted in the spring. In fall planting the earth should be raised ten or fifteen inches around the trunk of the tree. This preserves the roots from the frost. In the spring this must be taken away again. Trees that are frozen when received should be placed in a cellar free from frost or buried in the ground without unpacking until the frost has withdrawn; treated in this way they will not be injured by freezing.

\section{DISTANCES FOR PLANTING.}

Standard Apples, 30 to 33 feet apart each way.

Standard Pears and Cherries, 20 feet apart each way.

Standard Plums, Peaches, Apricots, is feet apart each way.

Dwarf Apples, Pears, Cherries and Quinces, Io feet apart each way.

Grapes, 8 feet apart each way.

Raspberries and Blackberries, rows 6 feet apart and plants 3 feet apart in a row.

Currants and Gooseberries, rows four feet apart.

Strawberries, rows 3 feet apart and $I_{\text {to }} I_{2}^{\frac{1}{2}}$ feet apart in the row.

\section{FOR HEDGES.}

Norway Spruce, Arbor Vitæ and Hemlock, I to I $\frac{1}{2}$ feet apart.

Japan Quince, Privet and Spirea, Io to I $_{5}$ inches apart.

Honey Locust and Osage Orange, 6 inches apart.

\section{FOR WIND-BREAKS.}

Norway spruce, 3 to 6 feet apart.

\section{NUMBER OF TREES OR PLANTS TO AN ACRE AT EQUAL DISTANCES.}

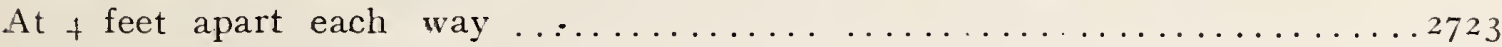

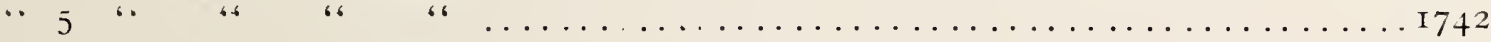

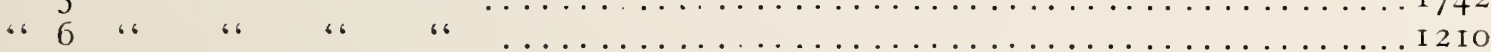

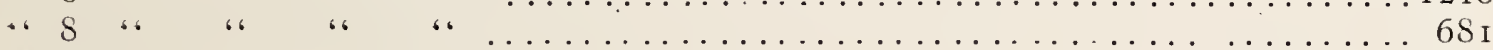

“10 “ ، “

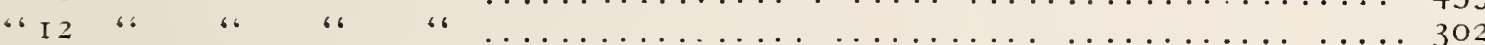

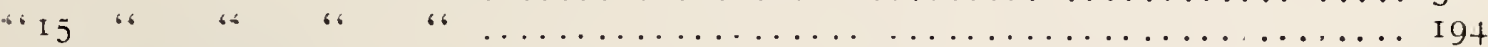

" 18 " $"$ "

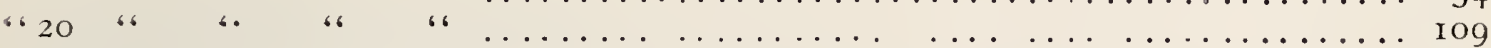

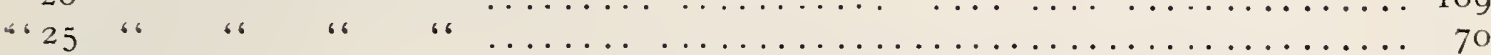

"

" 3 ، 


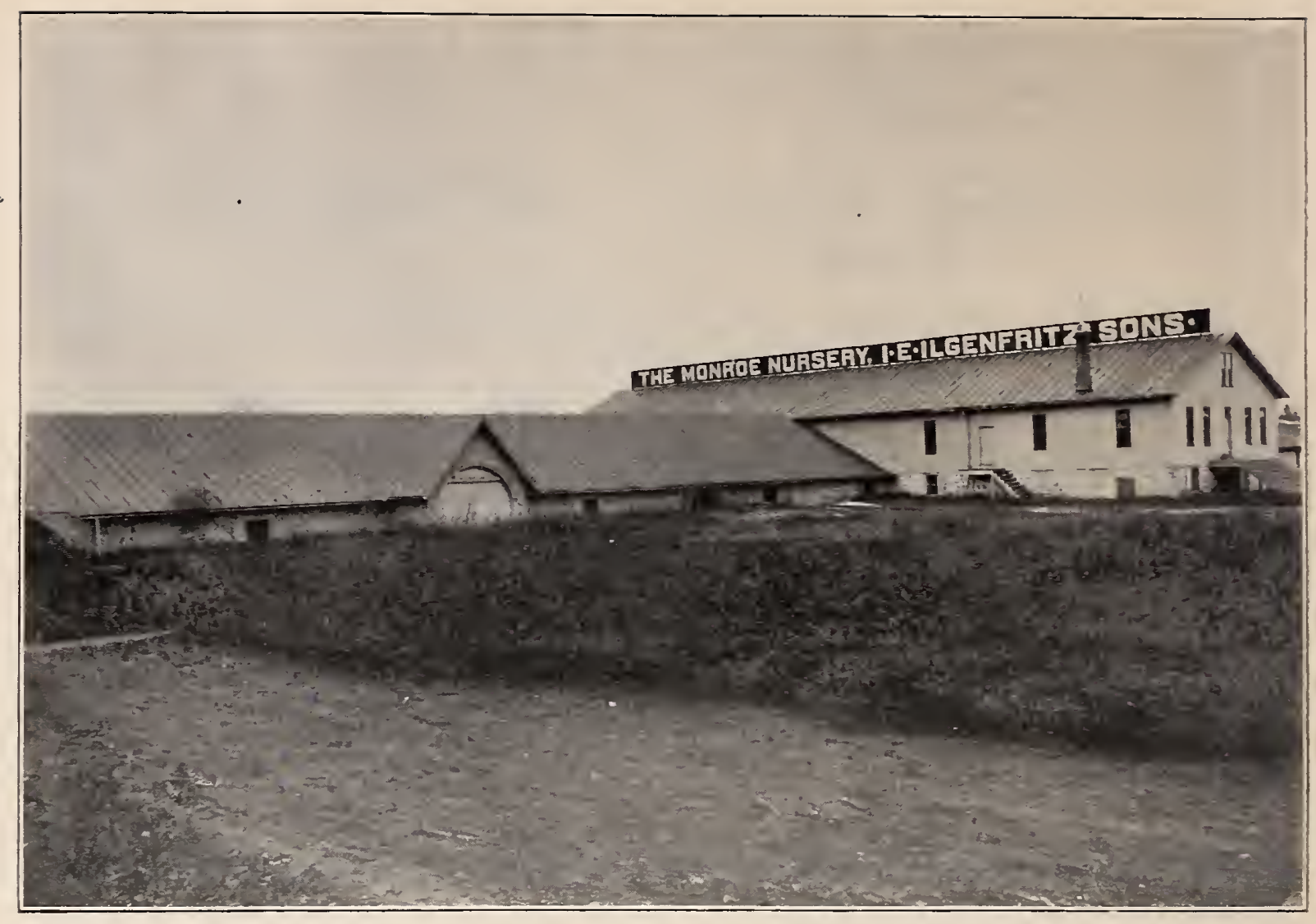

STORAGE CELLARS.-Nos. 1 and 2.

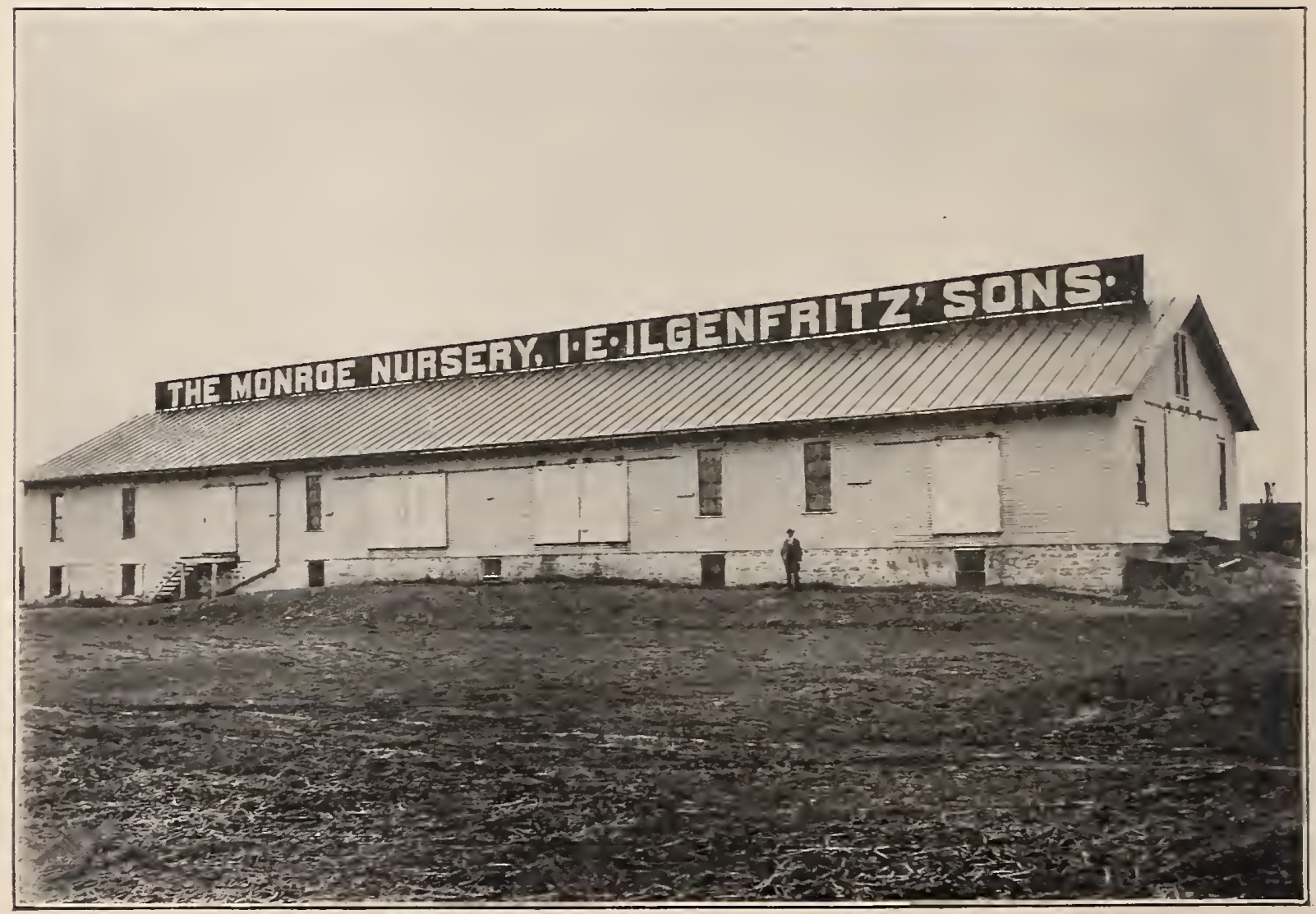

STORAGE CELLAR,-No. 2. 


\section{FRUIT DEPARTMENT. APPLES.}

Our stock of Apple Trees for the present year is large, thoroughly sound and unex. ceptionably fine, and comprises upwards of one hundred of the most approved varieties in cultivation.

In the following described list, however, we have enumerated a select list of varieties generally approved for cultivation, and much superior to the general run. This will aid you in making a correct selection for your orchard.

For a family orchard we would not recommend the planting of many varieties. A few of the best sorts is quite sufficient, if judiciously selected, to afford a succession of fruit throughout the year, for home and market.

Persons selecting trees for transplanting will find it to their interest to choose small, thrifty trees, three or four years old, and from five to seven feet high; as such are more safely transplanted, and with more satisfactory results than older and larger trees.

\section{Select Summer Apples.}

AMERICAN SUMMER PEARMAIN. - A rich, highly flavored fruit, much esteemed where it is known. It ripens gradually from the roth of August to the last of Septeniber. Fruit medium size, and oblong. It has smooth, red skin spotted with yellow in the shade, but streaked with livelier red and yellow on the sunny side. Flesh yellow, remarkably tender, and with a rich, pleasant flavor.

BENONI.- This excellent apple originated in Massachusetts. The tree is of vigorous, upright, spreading habit; hardy and productive. Fruit medium size, roundish, ob. late, conical. Color pale yellow, shaded, striped and marbled with dark crimson. Flesh yellow, juicy, tender, sub-acid. Core small. Ripens in August.

EARLY HARVEST (Yellow Harvest.) - Decidedly an American Apple. On account of its excellent qualities should be in every collection. It begins to ripen the first of July and continues during all the month. Very fine for " eating out of hand," and for cooking. Tree moderately vigorous, upright and spreading. The fruit is round. ish. medium in size, and is of a bright straw color, with a smooth skin. Flesh very white, tender and juicy - crisp with a sprightly flavor.

IKESWICK CODIIN._-"A noted English cooking apple, which may be gathered for tarts early in August," and continues in use until November. The tree is an early and abundant bearer, very hardy, and a strong grower. Large, regular and spreading. Fruit is greenish yellow, washed with a faint blush on one side, and is a little above medium size. The flesh is yellowish white - very juicy, and has a rather sprightly acid flavor. Very good.

PRIMATE.- We consider this one of the best North American summer apples. The tree is very hardy. A strong and stocky grower, and very productive. Fruit medium to large. Color greenish white, tinged with a crimson blush on the exposed side. Flesh white, very tender and refreshing. The beauty of this apple as a fruit for home zonsumption is that it ripens gradually, and lasts for a long time. It is equally good as a cooking and dessert apple, and those who are fortunate enough to possess it consider it their favorite summer apple. 
RED ASTRACHAN. (Ab Lincoln.)- This apple is of extraordinary beauty, an abundant bearer, and its rich color is heightened by an exquisite bloom. It is an importation from Siveden. Tree a vigorous grower, upright and spreading, and an early bearer. Fruit pretty large, rather above the medium size. Color a rich crimson, sometimes in the shade a little greenish yellow, and is covered with a pale white bloom. Flesh white, crisp. juicy, with an agreeable acid flavor. Excellent. Ripens in July to middle of August.

SWEET BOUGH. (Large Yellow Pough.) - A sweet apple, ripening in harvest timeconsidered fine for the dessert, but too sweet for pies and sauce. Fur those who wish an early sweet apple, this apple is worthy of a place in their collection. Fruit medium, pale yellow. Flesh white and crisp. Ripens middle of July to roth of August.

YELLOW TRANSPARENT.- This new Russian variety is especially adapted for a cold climate. Trees bear very young. Occasionally we find beautiful specimens of fruit on trees in the nursery row. The fruit is large, finely formed and showy, and a pale yellow in color. Flesh delicate and tender, sprightly, subacid, and of very good quality. Tree is a handsome grower and an abundant bearer. July and August.

\section{Select Autumn Apples.}

ALEXANDER.- A very large and showy Russian variety. Tree vigorous, spreading and productive. Fruit very large and regularly formed and of a fine appearance. Color of a greenish yellow, slightly streaked with red in the shade, but orange and brilliantly marked with bright red in the sun. Flesh yellowish white, crisp, tender, and juicy. Pleasant flavor. October to December.

CHENANGO STRAWBERRY.-- Originated in the state of New York. Tree is a vigorous grower, of spreading habit and an abundant producer. The fruit is medium in size, beautiful in color and much esteemed for the table. It is of an oblong shape, brightly striped with red and crimson over a whitish back-ground. One of our most showy and beautiful apples. The flesh is white, tender, juicy and sub-acid, with a most pleasing flavor. September and October.

DUCHESS OF OLDENBERG.-A Russian variety of remarkable beauty, and one of the most hardy and productive varieties under cultivation. Does especially well in sec. tions that are too cold for ordinary varieties. Tree is a vigorous grower and it requires little or no pruning, producing an abundance of fruit very even in size, which always sells well in market, and is a money maker. Fruit medium in size. Smooth skin, finely washed and streaked with red on a golden ground, covered with a faint blue bloom. Flesh juicy, sub-acid. Ripens the fore part of September.

FALL PIPPIN.-- Decidedly an American apple. A noble fruit, considered by all to be one of the very finest of Fall apples. Beautiful, of large size, delicious flavor and unexcelled for table or cooking purposes. Tree very vigorous, strong grower. Fruit very large, with smooth, yellowish green skin; when fully ripe, a golden yellow. Flesh white, very tender and mellow. Rich delicious flavor. October to December.

GRAVENSTEIN.-A German apple, originated at Gravenstein in Holstein. Thought to be one of the best apples in Northern Europe. It does fully as well in this country, and is unquestionably a fruit of merit. Tree an early bearer and a vigorous, spreading grower. Very productive. Fruit large, greenish yellow at first, changing to bright yellow, marked with deep red and orange. Flesh tender and crisp. Highly flavored. Valuable for market and cooking. September and October. 
MAIDEN'S BLUSH. - A remarkably beautiful apple. It begins to ripen about the latter part of August and continues until late in October. A very desirable variety for cooking or market, also one of the best for drying. Tree is handsome, a rapid grower, and bears large crops. Fruit very regular and beautifully marked with red and yellow. Flattened at the ends and of a waxen appearance. Flesh white, tender and pleasant. October and November.

MUNSON SWEET.-Tree a vigorous grower, and an annual and abundant bearer. Fruit medium to large, pale yellow with red cheek. Tender, juicy and good. For those who wish a good, substantial, Fall sweet apple, this variety meets the requirements. October and November.

OHIO NONPAREIL. - A very valuable Autumn apple, either for market or table use. Tree vigorous, spreading and requiring little or no thinning. Fruit evenly distributed over the whole tree. Uniform, smooth and good size. Yellow, shaded and marbled with red and sprinkled with gray dots. Flesh yellowish white, fine-grained, tender, juicy and rich. Sub-acid. Core small. It has been said it is "better than the best." October and November.

TWENTY OUNCE APPLE (Cayuga Red Streak).-A large and very showy apple. Thought to have originated in Connecticut. Tree thrifty, a good and regular bearer. Fruit of fine appearance, extra large in size. Greenish, splashed and marbled with reddish purple. Flesh coarse grained, with sprightly flavor. Popular in the market. October to December.

\section{Select Winter Apples.}

ARKANSAS BLACK. -Originated in Arkansas. Tree is very hardy and thrifty. An early and uniform bearer. The fruit is large, round and smooth. Very black and dotted with whitish specks. Flesh yellow, very juicy and of a delicious flavor. It is remarkable as a keeper. Specimens have been kept as late as August. New.

BALDWIN. - This apple stands at the head of all New England apples, and is unquestionably one of the best apples cultivated. Tree vigorous, upright and spreading. An abundant and regular bearer. Does well in all sections of the country. Fruit large and roundish. Yellowish in the shade, but nearly covered with crimson, red and orange where exposed. Russet dots. Flesh yellowish white. Crisp and very highly flavored.

BENTLEY SWEET.-Tree vigorous and hardy. We consider it the best long keeping sweet apple. Fruit medium size; roundish; flattened at the ends; sometimes slightly oblique; pale yellowish green shaded with pale red. Flesh whitish; compact; sweet as honey, and with small core. An excellent apple. Of all winter sweet apples, this is the most desirable.

BELLE DE BOSKOOP.-A Russian apple. Tree vigorous and spreading. Comes into bearing quite early and produces fruit of fine quality abundantly. A most promising variety. Fruit medium to large. Skin yellow, shaded with red nearly over the entire surface. Flesh crisp, juicy, tender, sub-acid, rich and good flaror. Close small core. This apple is valuable in a cold climate and in exposed sections. Stands among the very best importations from Russia and is a long keeper.

FAMEUSE (Snow Apple).-A very celebrated Canadian apple. It derives its name from the snow white color of its flesh, and is considered par excellent. Brings the top price in niarket, and as a table apple is renowned. Tree moderately vigorous, hardy and very productive. Fruit medium size, roundish, somewhat flattened. Color pale gellowish green ground with light streaks of pale red, deepening to a deep rer in the sun. Flesh exceptionally white, fine and juicy, with a fine perfume. 
GIDEON.-A recent introduction from Minnesota, and said to be as hardy as the native oak. Vigorous and an early, productive bearer. Fruit medium to large. Color a ich golden yellow, covered on the sunny side by a handsome blush. Flesh fine, juicy, sub-acid. It adheres well to the tree, and is an excellent keeper.

GRIMES GOLDEN PIPPIN.-A valuable American apple of extreme hardiness, « ..... stands injury during severe winters, and never breaks in its limbs. An annual and productive fruiter. Tree vigorous, upright and spreading. Fruit medium size, yellowish, slightly russetted, fine grained, juicy, rich and spicy. Excellent for dessert. A long keeper.

GAN0.- A seedling of the Ben Davis, but is much superior to that variety, having all of its good qualities in a higher degree. It is more brilliantly colored, more regular in size, and a very long keeper. Trees have withstood 32 degrees below zero without injury. Is a rapid grower, bears while young, and is an annual producer of large crops. Fruit large, finely colored bright red, very even in size, and good quality. February to May.

JONATHAN.-Originated in the state of New York. Succeeds wherever grown. Perfectly hardy and is productive in all soils, which makes it one of the most desirable apples. Fruit of medium size, very regularly formed. Skin thin and smooth. Yellow ground almost covered with lively red stripes deepening into dark red in the sun. Flesh white, very tender and juicy with a vinous flavor. Very valuable for hoine use or market. It is a long keeper.

LONGFIELD.-- One of the best new Russian varieties. Tree is a very strong, upright grower, and has proven itself to be an early, annual and abundant bearer. Highly valuable for cold climates and exposed sections. The fruit is white, tender, fine and juicy, sprightly sub-acid, and keeps from December to April. Something new, and a valuable addition to our American orchards.

MANN.- A chance seedling from New York. Tree very hardy; is upright in growth, bears annually and early. Fruit good size and very even. Skin deep yellow when ripe. Flesh yellowish, juicy, mildly sub-acid. It resembles the Rhode Island Greening, although it keeps much longer, maturing after the Greening is gone, remaining firm and handsome until late in the Spring. It is eminently valuable as a cooking and eating apple for late spring use. Bears very young and large crops.

NORTHERN SPY. - Might be termed the King of the American orchard. It is one of the most delicious, fragrant and highly prized of all late dessert apples. Always commands the highest market price, and is one of the very longest keepers. Tree is a rapid, upright grower. Fruit large. Skin smooth. Greenish or pale yellow in the shade, striped with red in the sun, and covered with a thin, white bloom.

NORTHWESTERN GREENING.-- Originated in Northern Wisconsin, where it is much esteemed on account of its extreme hardiness, having withstood 50 degrees below zero. without damage. Tree good, thrifty grower. Fruit large and of fine appearance, nearly round and very regular. Rich yellow in color when fully ripe. Flesh yellow, juicy, flavor rich and good. An excellent long keeper.

RED CANADA. (Steel's Red Winter.)--An old and tried variety, and considered one of Michigan's best apples. Tree thrifty, but of slender growth, very productive. Fruit medium, oblate, inclined to conic. Skin yellow mostly shaded with deep red, and sometimes covered with greenish dots. Flesh very white and juicy, retaining its rich flavor to the last. $\wedge$ long keeper. 
SALOME.-- Originated in Illinois, and does remarkably well in the Northwest. Tree is a hardy, vigorous grower, bears fruit young and very abundantly. Its hardiness, good quality, and uniform size recommend it. Fruit a little below medium, roundish, slightly angular. Skin pale yellow, shaded and splashed with red. Flesh whitish yellow, tender, juicy. A long keeper.

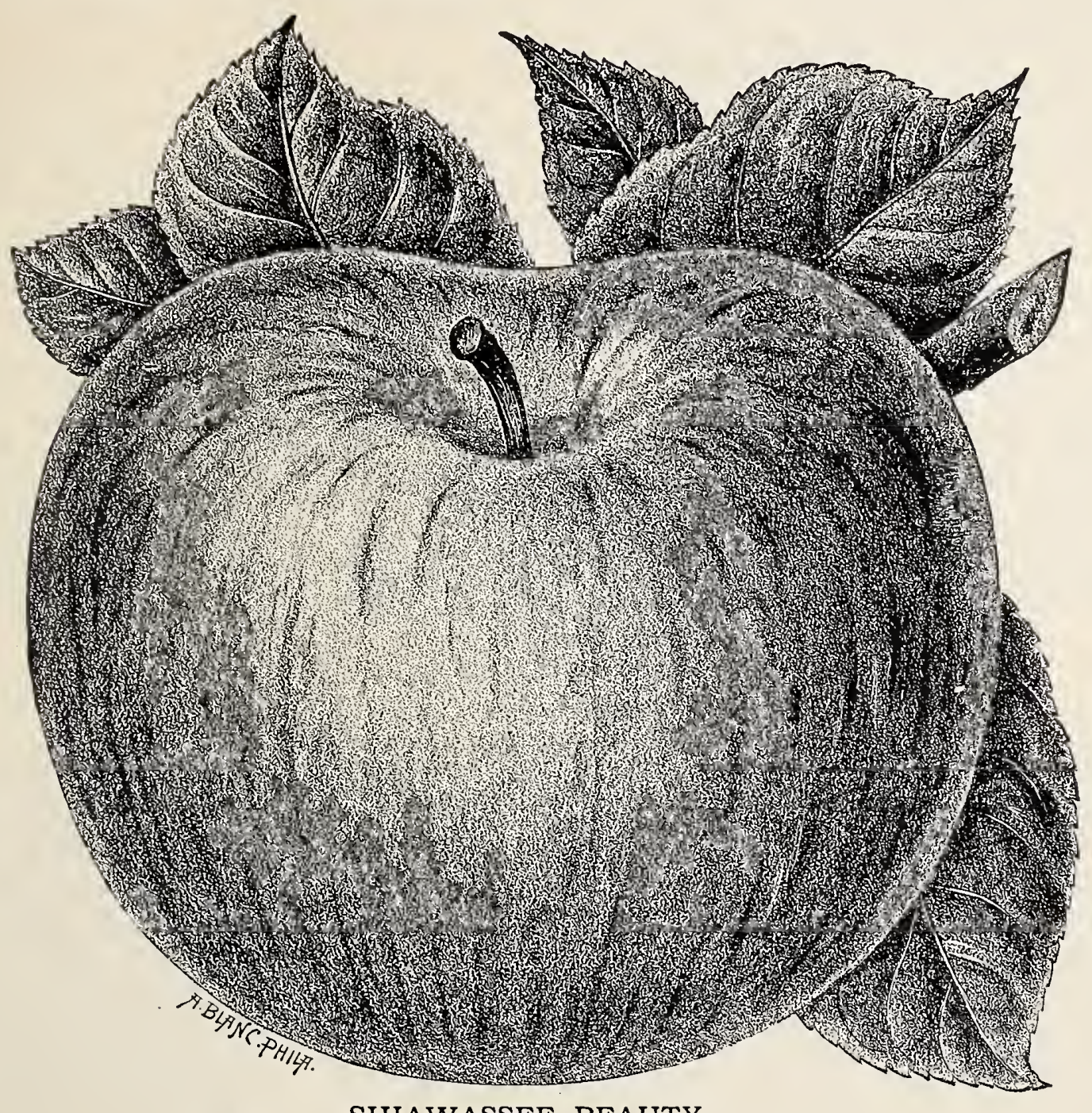

SHIAWASSEE BEAUTY.

SHIAWASSEE BEAUTY. (Michigan Beauty.)-- Originated in Shiawassee Co. Michigan. Said to be a seedling of the Snow, resembling that variety very much in the fine quality of its flesh, although much larger and more beautiful in appearance. Tree is a strong, upright grower, extremely productive and very showy. We have this tree in fruit on our packing grounds, and when covered with fruit, as it is every season, it calls forth many exclamations of astonishment from those who see it, for the remarkable beauty, the quantity, quality and size of the fruit. A thin skin, very smooth, deep red which takes a high polish. Flesh very white, fine, crisp, extremely juicy. One of our very best late Fall, early Winter apples.

SUTTON'S BEAUTY.-- Originated in Massachusetts, and has grown into popular faror on account of its marketable qualities. It gives the best of satisfaction wherever planted. Tree a free and handsome grower, and rery productive. Fruit medium to large, roundish, liandsome, waxen in appearance. Color yellow, beautifully striped with red. Flesh tender, white, juicy and sub-acid. A remarkably long keeper. Considsred one of the very hest winter apples on account of its beauty and ready sale in the market. 
STARK.-- Large, greenish yellow, shaded, splashed and striped with light and dark red; flesh yellowish, moderately juicy; a long keeper and valuable market apple. Tree very vigorous and hardy.

WALBRIDGE. (Edgar Red Streak.)-- Medium size, whitish yellow, shaded and striped with red; flesh white, fine, tender, juicy, mild, sub-acid. Tree a good grower, very hardy and productive. January to May.

WAGENER. We consider this one of our very best winter apples. For several years there has been quite a demand for this apple in Northern Michigan, where it does remarkably well and brings the top price in the Chicago market. Tree thrifty, upright, hardy. A very early and abundant bearer. Fruit a little above medium, handsomely shaped. Yellow mostly shaded with crimson. Flesh yellowish, very tender, juicy, and a most excellent table apple in every particular.

WEALT́HY. Originated near St. Paul, Minnesota. Of recent introduction. Was awarded first prize at the National Exhibit at New Orleans in competition with all the leading fruits. It is well named, being an extremely hardy variety. Rich in color and finely shaped. It will always sell well and should put money into the pockets of those who grow it. Tree handsome, free grower and exceptionally hardy. Fruit medium, roundish. Skin smooth, oily and mostly covered with dark red. A soor keeper.

We have in stock these additional varieties:-

Sumier VARIETIES:-Carolina Red June, Early Strawberry, Fourth of July, Golden Sweet, Summer Queen, Spice Sweet, Tetofsky, Western Beauty.

AUTUMr VARIETIEs:-Autumn Strawberry, Colvert, Flory, Gravenstein, Hass, Jefferies, Jersey Sweeting, Lowell, Peach, Porter, Red Beitingheimer, St. Lawrence, Stump, TwentyOunce Apple.

WiNTER VARIETIES:-Bellflower Yellow, Bailey's Sweet, Ben Davis, Bottle Greening, Belmont, Bethel, Babbitt, Clyde Beauty, Cooper's Market, Delaware Red, Esopus Spitzenberg, Flushing Spitzenburg, Fallowater, Green Sweet, Hubst'n Non'such, Hyde's King, King Tompkins Co., Ladies' Sweet, Lady Apple, Loy, IIcIntosh Red, Peck's Pleasant, Pewaukee, Raule's Janet, Rambo, R. I. Greening, 'Roxbury Russet, Golden Russet, English Russet, Seek no Further, Smith's Cider, Smoke House, Scott's Winter, Sweet Vandervere, Tallman's Sweet, Vandevere, Wagoner, Willow Twig, Winesap, White Pippin, Wolf River, York Imperial.

CADILLAC, Mich., May 4 , I89g.

I. E. Ilgenfritz' Sons, Monroe, Mich.,

Sirs, - En closed pleased find Draft for $\$ 36.0$ on to pay for trees. They came Monday morn ing, were in good condition and were very fine trees. I have been setting them out or would have sent Lraft sooner. When I need more trees, will send my order direct to you.

Yours truly, JOHN MANSFIELD.

LAKE MILLS, Wis., April 29, I899.

I. E. Ilgenfritz' Sons, Monroe, Mich.

Gentlemen,--The box of trees you shiped me got here the fifth day after being shipped. Everything was fresh and in good condition, Am Well satisfied with grade of trees. 


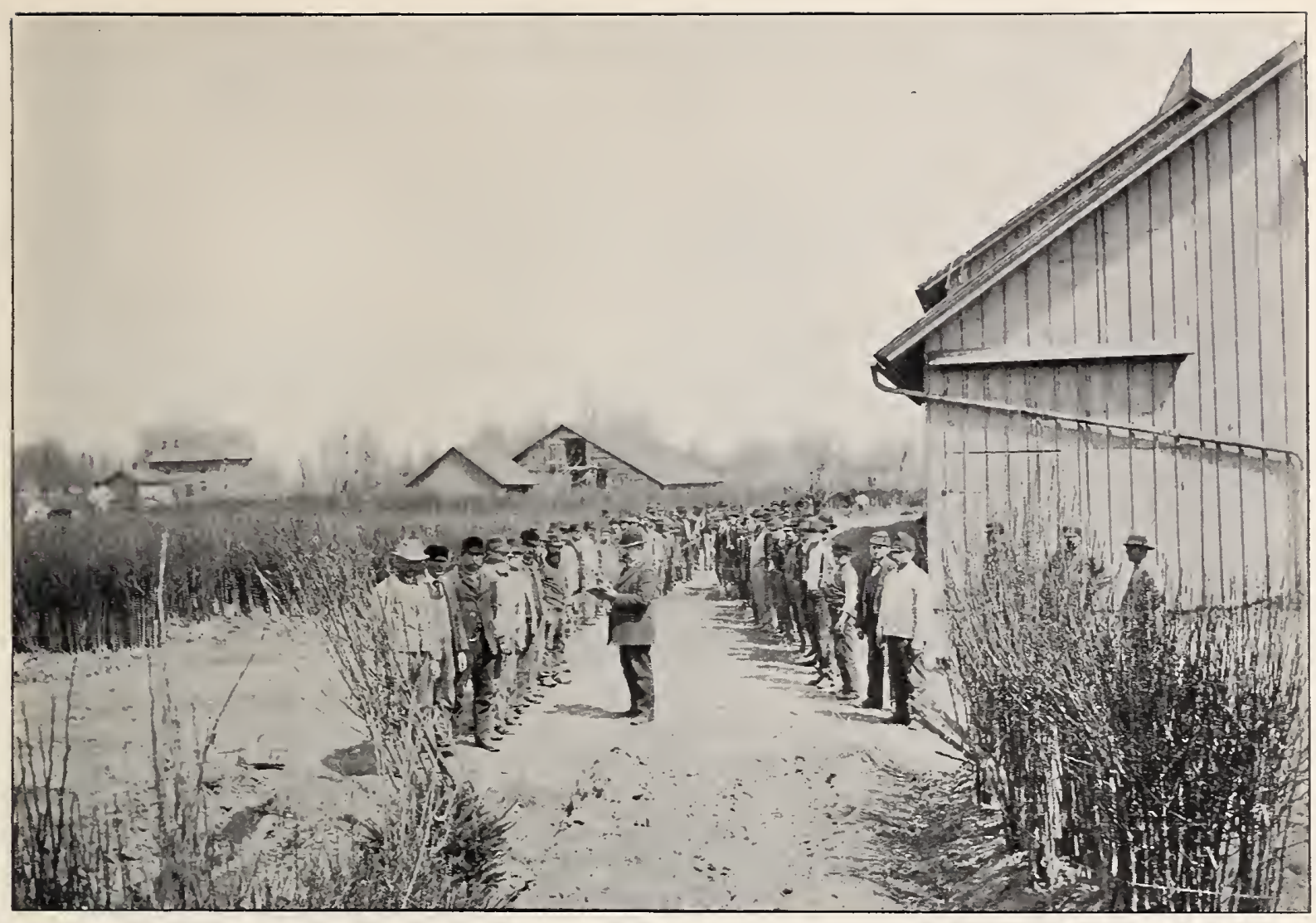

ROLL CALI.

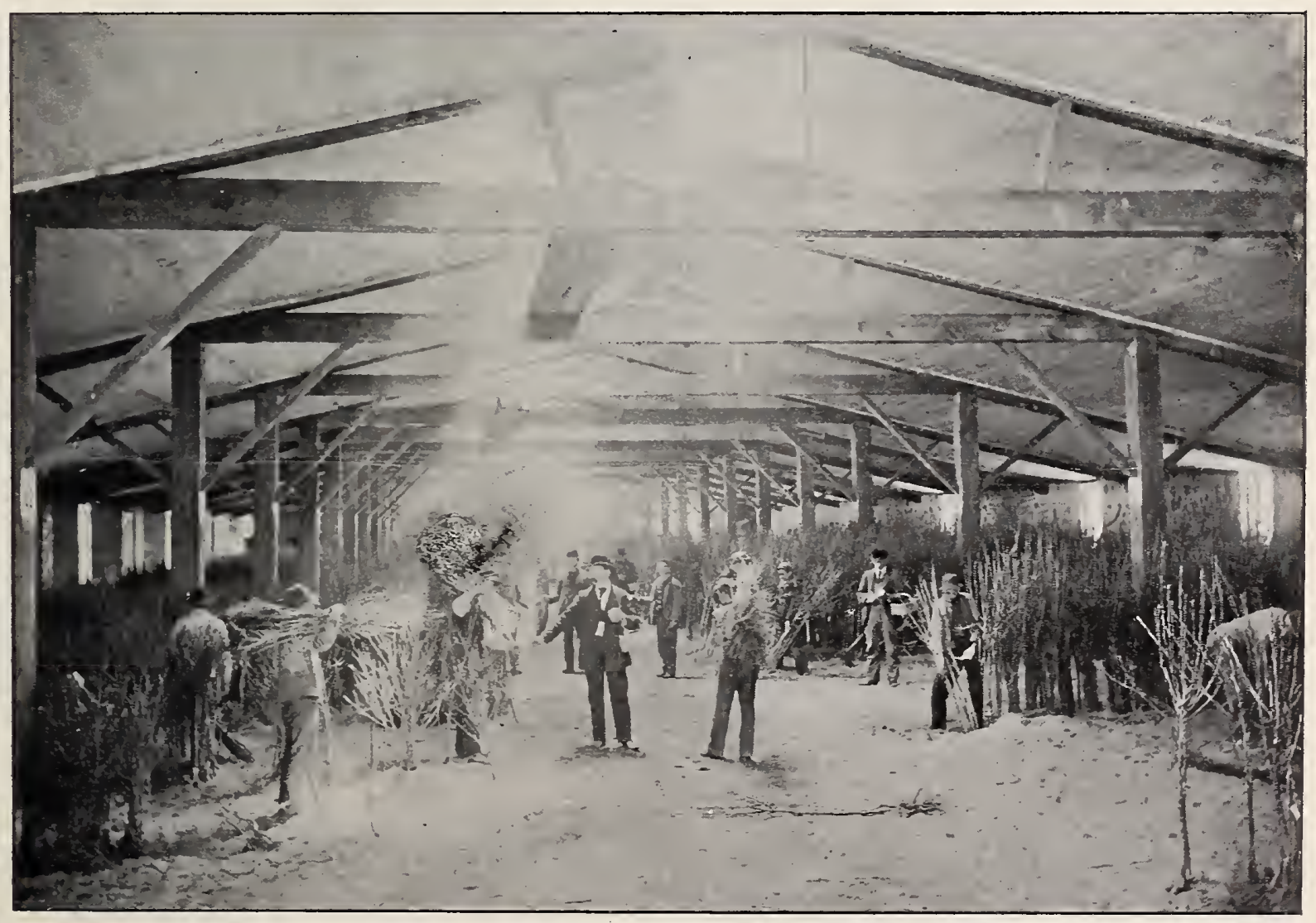




\section{CRAB APPLES.}

\section{Both Ornamental and Useful.}

The hardy and improved varieties of Crab Apples, some of which are of recent introduction and promise great excellence, supply a much needed want in the more northern portions of the United States and Canada, where little else in the line of fruit can be grown. And even in the more favored localities, where other fruits are raised in abundance, Crab apples are every year becoming more esteemed and cultivated. They combine the qualities of extreme hardiness and productiveness, being capable of enduring an extremely cold climate, and bearing annually large crops of highly colored and beautiful fruit, of which some varieties are excellent for the dessert, while others are valuable for drying, cooking and preserving, jellies, cider, etc.

Taking into consideration their extreme hardiness, early productiveness, beauty and value for culinary purposes, as well as some varieties for the dessert, entitle them to a place in every garden.

GENERAL GRANT. Fruit large, yellowish with broken stripes of dark red, and on the sun-exposed side becoming almost black red. Flesh white, moderately fine grained. Not juicy.

HYSLOP. - Fruit large, produced in clusters, roundish, ovate, dark rich red, covered with thick blue bloom. Stock long and slender. Tree hardy, vigorous, spreading. Very desirable, one of the very best.

MARTHA. A new Crab raised from the seed of the Ducliess of Oldenberg by P. M. Gideon of Minnesota, who has this to say of it: "A rapid stiff grower. A perfect pyramid in tree. A great bearer of the most beautiful fruit we ever grew. A bright, glossy yellow shaded with light, bright red. A mild, clear tart, surpassing all other crabs we ever grew for all culinary purposes, and fair to eat from hand. Season October and November."

TRANSCENDENT. One of the largest and finest of this class of apples. Tree a strong grower and good bearer. Very hardy and much sought after in the North and Northwest. Skin golden yellow, striped with rich red. Flesh yellow, crisp, juicy. Excellent variety for general use. September and October.

VAN WYCK SWEET. A new and exceedingly valuable variety. Fruit very large. Skin yellowish white, colored light red, and covered with bloom. Flesh yellowish white. Very sweet and tender. Core small. A vigorous grower.

WHITNEY. Tree a fine grower, with dark green, glossy foliage. Fruit exce : mally large. Skin smooth, striped and splashed with red. Flesh yellowish w wite, very juicr and pleasant flavor. Considered by some a fine dessert apple. A great bearer. and verv nardy.

We have in stock these additional varieties:-Lady Elgin, Large Red Siberian, Large Yellow Siberian, Marengo, Montreal Beauty.

I. E. ILGENFRITZ' SoNS,

MIOoRestown, Mitch., June $28 \mathrm{ht}$ h, IS97.

Dear Sirs,-Your trees are all living and doing well. They are the first trees that $I$ have had that has lived. I want enough to set out a ten acre orchard as soon as I can get them.

Yours truly,

WM. CANTINELL. 


\section{PEARS.}

THE Pear very justly ranks as one of the most delicious fruits of modern times. It has been placed first by nearly all modern anateurs, on account of its fine, juicy texture, exquisite flavor and aroma. Of late years great attention has been given to the cultivation of this favorite fruit, and those who have entered upon its cultivation for the market intelligently, have found it to be one of the most profitable occupations.

In consequence of the demand upon us for trees, and having a soil and climate peculiarly adapted to the production of this fruit tree in its perfection, we have entered largely upon its cultivation, and we have on hand, in the various stages of growth, a large and fine stock.

Our collection of varieties is extensive, and consists of the most approved sorts in cultivation.

In the standard form the pear undoubtedly succeeds the best, and with the least care. When once well established in a favorable soil and situation, it requires but little attention. An occasional cultivation of the soil about the tree and a light pruning is all that is necessary to insure success.

Sorl.-The soil most congenial to this fruit tree is a strong clay loam, but will succeed in any good soil, provided it is moderately rich, and dry. A soil saturated with a stagnant moisture for a large portion of the year, is totally unfit for this purpose.

DistaxcE. - The usual distance at which to plant standard trees is about twenty-five feet each way. If the soil is not very strong, twenty feet is sufficient.

Dwarf Pears. - These are budded on the Anger's Quince, which is the best stock for this purpose. In favorable localities, and with careful culture, they are often made to yield good crops; but for general cultivation we would recommend the Standard tree.

Picking and Ripening.-Early and Autumn Pears should be picked ten days before fully ripe, and allowed to ripen in the house. This greatly improves the flavor of nearly all kinds, while some are nearly worthless if allowed to ripen on the tree.

Winter pears should be picked before severe frosts, and placed in a cool cellar, till it is desired to ripen them; when if placed in drawers in a warm room they will ripen in a few days.

\section{Select Summer Pears.}

BEURRE GIFFORD.-- A chance seedling imported from France. An early pear of value. We have had this tree in fruit for some time, and consider it one of the best early pears we ever grew. Flesh white, melting, juicy, and with an excellent vinous flavor. Middle of August.

BARTLETT.-One of the most popular pears. Large, buttery and melting with a rich musky flavor. A good, erect grower. Bears young and abundantly. Always sells for the top price in the market. A delicious eating pear, and makes the finest of canned fruit. August.

CLAPP'S FAVORITE. - Tree a vigorous, upright, spreading grower. Very hardy and productive. Fruit very large, of uniform size, pale lemon yellow, when exposed to the sun faintly splashed with crimson and fawn. Flesh fine grained, juicy and buttery, of exquisite flavor. One of the best. Last of August.

WILDER.--One of the earliest. A good keeper and shipper. Tree very vigorous, bears young and abundantly. Extremely hardy. Fruit very beautiful. bell shaped. Surface smooth, pale yellow ground with dense shading of brownish carmine. Flesh whitish yellow. Fine grained, tender. Flavor sub-acid, sprightly. Ripens August Ist, and does not rot at the core (a failing in most all early pears). Excellent, and brings a good price in market. 


\section{Select Autumn Pears.}

ALBERTINE $\angle$ This great Belgian pear is one of the most vigorous of trees, and exceed. ingly profitable as a market sort. It is upright, spreading and large, producing heavy crops annually. Fruit is very large, roundish in form, deep yellow in color. The flesh is buttery, juicy, melting, sweet, aromatic and excellent. This variety succeeds in almost any climate, and as a shipper is not excelled. Very fine for table use. September and October

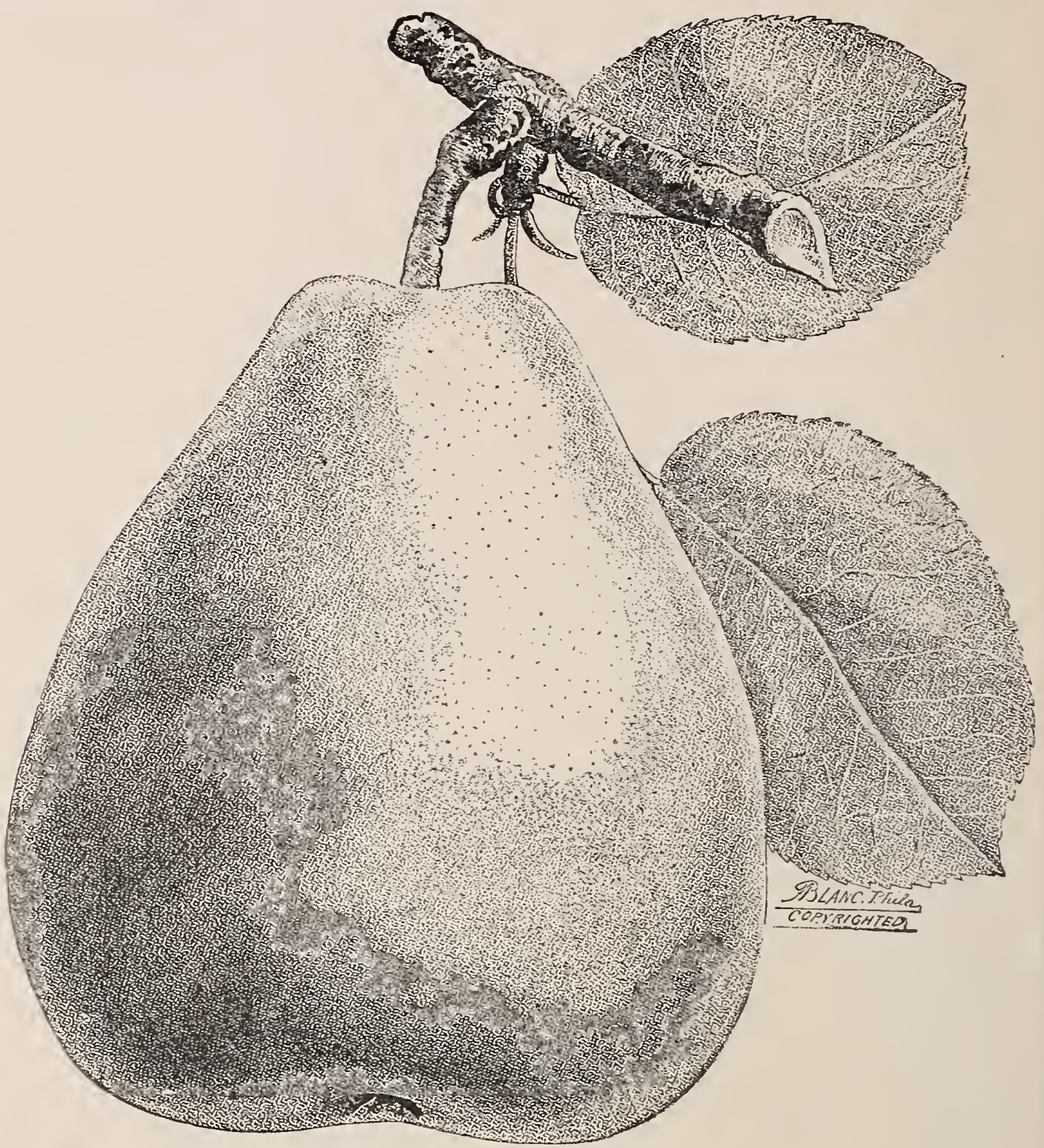

ALBERTINE.

BEURRE D'ANJOU.-- A noble fruit of French origin. Tree vigorous and productive. Fruit large and handsome. Skin greenish sprinkled with russet, and sometimes with red cheek. Flesh melting, buttery, perfumed and excellent. A very good keeper. and should be in every crchard. Considered by all to be one of the best. November.

BEURRE CLAIRGEAU.-- Very large, fine, melting, highly flavored pear. Tree a good grower, forming a pyramidal shaped tree, and is an early and abundant bearer. Fruit very large, attractive appearance when on the tree and very showy in the market. Color warm yellow shaded with fawn, orange and red. One of the best and a long keeper. October and November. 
BEURRE SUPERFINE.-- This is an excellent pear of French origin. Tree very healthy, hardy and vigorous: bears good crops. Fruit large, fine, melting, with a sprightly, pleasant flavor. Color a rich yellow slightly shaded with crimson. Highly appreciated by those acquainted with it, and without doubt one of the best. Ripe all of October.

FLEMISH BEAUTY. - A large, melting, sweet pear. Tree vigorous, very hardy, bears early and abundantly, and succeeds well in nearly all parts of the country. A most valuable variety for general use and market. Fruit large, surface a little rough, the ground pale vellow, but mostly covered with marblings and patches of light russet, becoming reddish brown at maturity on sunny side. Fine shipper and sells well. September and October.

HOWELL.--Originated in Connecticut. A valuable variety. Tree grows freely and is up. right: an early and productive sort. Fruit large and roundish. Light waxen yellow, sometimes with a finely shaded cheek. Flesh whitish, juicy, melting, vinous. Considered very hardy in the West. September to October.

IDAHO. - This celebrated pear is a native of Idaho, and stands without injury very cold winters: has stood 30 degrees below zero and borne good crops. A thrifty grower. Succeeds well in all sections: stands dry weather remarkably well, having borne crops when all others failed on account of the drought. We have it in fruit, and consider it exceedingly fine. The Rural New Yorker says of it: "It is altogether a remarkable pear. There is no other pear known to us that is more distinct in shape. No other that is seedless. The flesh is white and exceedingly fine-grained. Very tender and buttery, with a rich, subdued acid flavor. Even when dead ripe it makes no approach to insipidity. It is a month later than the Bartlett, and decidedly a better keeper." It is recommended by the U. S. Department of Agriculture.

KEIFFER. (Keiffer's Hybrid.) - This new and unique pear is said to have been raised from seed of a Chinese Sand Pear, accidentally crossed with Bartlett or some other kind grown near it. Fruit large, of fair quality and very showy. Tree vigorous, hardy, an early bearer and produstive; succeeds best as a standard. In appearance is one of the most beautiful of pears. It thrives in nearly all sections. Some praise it very highly, while others do not think so much of it, but the fact that large fruit growers are planting whole orchards of it proves it to be a profitable variety. Its large size and handsome appearance cause it to sell readily in market. It is apt to overbear, and care should be taken to prevent it. Requires thinning. October and November.

SHELDON.-Fruit rather large: roundish. yellowish, nearly covered with light russet; shaded with red. Flesh very juicy, melting and delicious. Tree hardy, erect, vigorous and good bearer. Considered one of the best varieties, and when properly ripened (by picking before ripe and placing in a dark room), there is no variety superior to this one. October.

SECKEL. - The standard of excellence in the pear. Small, but of highest flavor. Tree a stout, slow, erect grower. Nakes a beautiful tree either as a standard or pyramid. Downing pronounces this American pear the richest and most exquisitely flavored variety known. The healthiest and hardiest of all pear trees, bearing regular and abundant crops in clusters at the ends of the branches. September and October.

VERMONT BEAUTY. A beautiful new seedling pear. Medium size, roundish, yellow, nearly covered with carmine. Flesh melting, sprightly, fine quality. Tree healthy, hardy and productive. An abundant and early bearer. The Rural New Iorker says: "The fruit ripens a little later than the Seckel, and much excels that variety in size and beauty. The flesh is rich, juicy, aromatic. It cannot do otherwise than stand at the head of our Fall pears." October. 


\section{Select Winter Pears.}

LAWRENCE.-An American pear of great excellence. Trees hardy, an early and abundant bearer. Fruit medium size, very regular. Color lemon yellow. Flesh whitish, juicy, melting, sweet and aromatic. Considered one of the very best winter pears. We have several hundred trees of this variety planted in one of our orchards, and expect great returns from them. December to January.

WINTER NELLIS.--This is indeed an exquisite pear. Downing says : "It liolds nearly the same rank among winter pears that the Seckel does among the Autumnal varieties." And he knows whereof he speaks. We have had this variety in fruit for several years, and it stands high in our favor. Medium in size, or usually a little below medium. Yellowish green at maturity, dotted with gray russet, and with russet patches and streaks. Flesh yellowish white, fine, juicy, buttery and melting. Do. cember and !añiâry.

We have in stock these additional varieties:

Summer Varieties. Bloodgood, Brandywine, Doyenne d'Ette, Lawson, LeConte, Margaret, Mannings Elizabeth, Madeline, Osband's Summer, Rostiezer, Souvenir de Congress, Tyson, Pelle Lucrative, Buerre Diel, Buerre Bosc, Belle de Beaufort, Brockworth Park, Buffam.

Autumn Varieties. Duchess d'Angouleme, Des Nonnes, Doyenne Boussock, Doyenne White, Edmunds, Frederick Clapp, L. Bonne de Jersey, Onondago, Oswego Buerre, Steven's Genesee.

Winter Varieties. Buerre Gris d'Hiver, Dana's Hovey, Doyenne d'Alencon, Easter Beurre, Glout Morceau, Mount Vernon, President Drouard, President Maas, Vickar of Winkfield.

\section{Dwarf Pears.}

DUCHESS d'ANGOULEME.-The best dwarf pear grown. Originated in France, the largest of all good pears, sometimes weighs as much as a pound and a quarter, of extra fine quality. Tree a strong grower. Fruit greenish yellow, streaked and spotted with russet; flesh white, buttery and very juicy, and of excellent flavor. October and November.

BARTLETT.-One of the most popular pears ; large, buttery and melting, with a rich, musky flavor. A good, erect grower; bears young and abundantly. August.

CLAPP'S FAVORITE.--Tre= a vigorous, upright, spreading grower, very hardy and productive. Fruit very large, of uniform size; pale lemon yellow ; flesh fine grained, juicy, buttery, melting, sweet and rich. Last of August.

DOYENNE D'ETTE. (Summer Doyenne.)-A beautiful, melting, sweet pear; rather small. Tree a fine grower and bearer. First of August.

FLEMISH BEAUTY.--A large, beautiful, melting, swee hardy and productive. Succeeds well in most parts of the country. A most valuable variety for general use and market. September and October.

HOWELL.-A fine, large pear, very handsome ; a good grower, and does well on quince ; very good. September to October.

LOUISE BONNE de JERSEY.--This is one of the most desirable for cultivation on the quince stock ; large, beautiful, first rate pear; yellow, with dark red cheek ; melting, buttery and rich; should be in all collections. September and October.

LAWRENCE.- Medium size; bright yellow; Flesh tender and melting; tree a good grower and abundant bearer ; the most valuable of our American Winter negrs. December and January. 


\section{PEACHES.}

THE best soil for the peach is moderately rich, somewhat sandy loam, but will succeed in almost any soil, except a heavy wet clay. The ground should be kept clean and mellow around the tree.

In the cultivation of the peach we would recommend the shortening in system. This should be done in February or March. Cut off from one-third to one-fourth of the previous year's growth. This course should be pursued every year. The trees so treated live longer, are broken down less by the wind, produce larger and better fruit, which is more easily gathered than from trees grown by the old method.

Careful examination should be made each season, and all the borers removed with a knife. A half peck of air-slacked lime or leached ashes placed around the trunk of the tree in May and allowed to remain until October, affords a good protection against the depredations of this pest.

We grow many thousand Peach trees annually. Orchardists wishing to purchase largely, would find it to their interest to correspond with us.

ALEXANDER.--A very early peach, fruit of medium size, round, skin covered with a rough down, pale, handsomely shaded on the sunny side; flesh white, tencier, melt. ing, juicy, rich. One of the best. Middle of July.

BRONSON. $\nvdash$ Large, yellow with handsome red cheek, flesh yellow, sweet, ricn, fins flavor; tree hardy and good bearer. One of the new Michigan peaches for which the demand has been very large during the past seasio

\section{6 "BILLMEYER."}

We are the Introducers and Exclusive Growers of this variety.

(SEE PHOTOGRAPH IN COLORS, BACK COVER.)

Not the earliest nor is it the latest peach to ripen. It has a season of its own. Every peach grower knows there is a time between the Early and the Late Crawford when there, is a dearth or scarcity of good fruit in the market. We now have the BILLMEYER, a "variety the excellence of which is unsurpassed. A variety that puts money into the pockets of the fruit raiser. The originator, Mr. Billmeyer, a man who has made himself rich out of raising the finest peaches drawn to market, reports: "The Billmeyer has made more money for me than any variety I grow as it comes to fill a long felt want. Right after the Early Crawford there is a scarcity of peaches; the Bilimeyer fills the gap, and I am therefore able to sell my peaches in a ready market at higher prices than at any other season of the year." (We have grown the Billmeyer peach for several years for Mr. Billmeyer's exclusive benefit.)

It is large, deep yellow, handsomely shaded with rich red; flesh yellow, firm, fine grained and juicy; pit exceptionally small. One of the best shippers in the long list of peaches, having been shipped over a Thousand Miles preserving its shape, texture and flavor. 
CRAWFORD'S EARIY.-A magnificent, large, yellow peach, of good quality. Its size and beauty make it one of the most popular orchard varieties. Fore part of September.

CRAWFORD'S LATE.-Very large, roundish, skin yellow, with a beautiful dark red cheek, flesh rich, yellow, melting, with sweet luscious flavor, worthy of universal cultivation as table and market sort. Latter part of September.

CROSBEY.-Originated at Billerica, Massachusetts, about I875, and recently brought to general notice on account of its extreme hardiness, bearing full crops of choice, attractive fruit when all other sorts have been blasted by frost. The fruit is of medium size, roundish, slightly flattened, with a distinct seam, bright orange yellow, streaked with red on the sunny side, flesh yellow, of a mild pleasant flavor. Tree of low spreading growth, similar to Hill's Chili. Promises to be very valuable for general cultivation. In season about with the Old Nixon.

EARLY RIVERS.-Fruit large, very white, with a delicate pink cheek, flesh melting, rich and luscious. An excellent peach. End of July.

ELBERTA.-Originated in Georgia, and is being planted most largely in the South, where it is regarded as the best market variety. Fruit large, yellow, with red cheek; flesh yellow, firm. juicy, fine quality. Tree very hardy and exceedingly productive. It is equally valuable in the North, and is one of the best general sorts for all sections. Ripens with Crawford's Early. During the past season this variety has become very popular in Michigan and Ohio. Exceptionally large and fine.

EARLY MICHIGAN. Yedium size, white with red cheek-handsome, flesh white, firm and of fine quality. An early and good bearer. Middle of August.

ENGLE'S MAMMOTH. $\forall$ Large, yellow ; resembles Late Crawford, but is more productive. Middle of October.

GOLDEN DROP. $\_$Large, golden yellow, with red cheek in sun, flesh yellow, juicy, rich and very good. A valuable variety. Tree very hardy, productive. Ripens betwe-1: Hill's Chili and Smock.

GREENBORO (New). - One of the finest early peaches yet introduced, far superior to tive Alexander and nearly twice the size of that variety. Introduced to the general public for the first time in I 896 . Fruit large, looks very inuch like a yellow peach, but flesh is white, fine flavor, very juicy when fully ripe; tough thin skin, peels off without the least trouble. An excellent shipper, and a freestone.

HILL'S CHILI._Large, downy, tame yellow, with slight blush, flesh yellow, luscious and well flavored, pit small. Tree hardy and productive. Bears large crops when most other sorts fail. Late September.

KALAMAZ00. Mr. R. Morrill, President of the Michigan State Horticultural Society, says of this variety: "Originated in Kalamazoo, attracted attention by bearing regular crops of large fruit of highest quality in a locality where the peach is considered a failure. A wonderfully strong grower, bears full loads of fruit at two years old, sets an enormous amount of fruit. My trees shed a large portion soon after bloom falls, but so far (four crops) have required some thinning. Size equals Early Crawford, more uniform, pit small. flesh thick, yellow, superb quality. Skin golden yellow with light crimson cheek: fewest culls of any variety I ever saw. Kalamazoo. Lewis and Gold Drop are our money makers, fully as reliable as a potato crop and grown as cheaply; bushel for bushel. Ripens between Early and Late Crawford."

LEMON FREE. - This is a magnificent peach of the Smock class, although it is earlier than that variety, originating in Summit county, Ohio. where it has proven itself to be hardier than any other good peach in that section. Its name is very appropriate, as it is almost lemon shape, a pale yellow in color. It is immense in size, the finest specimens measuring over twelve inches in circumference; excellent quality; exceedingly productive. One of the most valuable sorts for home use or market. 
LOCKWOOD. See illustration. This is the EARLiest Yellow-Fleshed Free-Stone grown, large, roundish, ripening fore part of August; skin orange yellow, with beautiful red cheek, flesh juicy, sweet, and deliciously flavored. Tree very productive, and fruit brings the top price in market. This is the first season that we have introduced the Lockwood, and as we have put in a large stock of buds, we will make a special run and put it into the hands of the peach growers at very liberal prices. Thəre is ro peach grown that is more popular where it is known. It has the quality of the Early Crawford and is three to four weeks earlier, and a great producer.

Our illustration of this peach is a reproduction from a photograph, which was taken during the summer of 1895 .

This is what large and experienced peach growers say of it:-

I. E. Ilgenfritz' Sons, Monroe, Mich.,-

Castalia, Ohio, May i2, i8g6.

Gents,--I consider it the very best early yellow free-stone peach that I have ever seen. Nearly as early as Early Rivers, perfect free-stone, good size, handsome and of good shipping qualities. Have seen it fruiting the last three years. Yours,

HENRY GERMAN.

I. E. Ilgenfritz' SoNs, Nonroe, Mich.,--

Gypsum, Оніо, May г2, г8g6.

Gentlemen,--Undoubtedly it (the Lockwood) is one of the best, maturing at a time when nothing else is ripe, and being a yellow meated free-stone, certainly deserves a place in any commercial orchard. I have set about 300 this spring, and they seem to be strong growers.

Respectfully yours,

IV. M. Hewitt, Mgr.

The Island and Gypsum Fruit Co.

Gypsum, Oнio, May iо, I8g6.

MímsRs. I. E. Ilgenfritz' SoNs,-

Ijear- Sirs, - The Lockwood peach is the best early yellow free-stone that we have, following the Early Rivers.

Yours truly, T.S. Johnsox.

E. E. Tucker, R. R. Agent, Gypsum, Ohio, says: "You cannot speak too highly of the peach. I was in Mr. Lockwood's orchard the last three seasons, and the crop each season on these trees was the finest that I ever saw."

I. E. ILGENFRITZ' SoNS,--

Gypsum, Ohio, May I5, 1896.

Dear Sirs,-I first noticed this Lockwood peach in $180+$ and 1895 , and each season a good full crop of large yellow peaches. Ripens about a week after the Early Rivers. I don't know of any other peach equal to it that ripens at that time of the year.

H. W. ENGLEBECK.

LEWIS SEEDLING. One of the earliest free-stones, remarkably hardy and a very early and abundant producer. Tree vigorous and an annual bearer. Fruit medium to. large, handsome. skin greenish white with red cheek, flesh white, juicy, pit small. Middle to latter part of August. Very profitable.

MOUNTAIN ROSE.-Large, skin whitish, nearly covered with light and dark, rich red, flesh white. slightly stained at the stone. Very good and should be in every collection. Middle of August.

RICHMOND.-A valuable market variety of medium to large size, roundish, skin yellow. shaded with red, flesh yellow, a little red at the stone, melting, juicy, sweet. Ripe a few days later than the Crawford's Early.

SMOCK FREE (Beer's Smock). - Large, crange red or yellow, flesh red at the stone, moderately juicy and rich. var: of Gctober. 
SNOW'S ORANGE. Liledium size, orange yellow, with a deep dark red cheek. flesh yellow and red at the stone, good quality. Tree hardy and very productive. Fore part of September.

TRIUMPH.-A wonderful new peach, ripens with the Alexander, blooms late, has large flowers. and is a sure and abundant bearer, fruit large with very small pit, surface vellow, nearly covered with red and dark crimson in the sun, flesh bright yellow. SI,200 was paid for the original stock of this variety, and we now offer it for the first time.

YELLOW ST. JOHN.-Large, roundish, yellow, free-stone, ripens a little before Troth's Early, skin orange yellow, with a deep red cheek, flesh juicy, sweet and high flavned. One of the earliest of the yellow-fleshed free-stones. Tree very productive. Valu. able for market. Middle of August.

\section{We have in stock these additional varieties:-}

Amsden June, Allen, Barnard's Early, Bower's Early, Bergen's Yellow, Cooledge's Favorite, Conklin, Champion, Crane's Ea Yellow, Capt. Ede, Chair's Choice, Early York, Early Beatrice, Early Canada, Foster, Fitzgerald, Greenboro, George the Fourth, Globe, Hale's Early, Heath Cling, Jacques Rareripe, Large Early York, Lemon Cling, Morris White, Morris Red Rareripe, Old Mixon Free, Old Mixon Cling, Red Ch'k Mel'coton, Reeve's Favorite, Salway, Schumaker, Snow, 'Sneed, Stump the World, Steven's Rareripe, Steadly, Susquehanna, Troth's Early Red, Ward's Late Free, Wager, Wheatland, Wilder, Waterloo, Wonderful and Yellow Rareripe.

\section{E. Ilgenf RITz' Sors, Monroe, Mich.}

KINDERHOOK, MiCH., JAN. 2, I8g6.

Dear Sirs, - Last spring I received over I 500 peach trees from your nursery, besides other kinds of fruit trees, and have succeeded in making every tree live with the exception of I5 peach trees, or one to the hundred, a much better percentage than I expected as the season was extremely dry. They not only lived, but made an extra fine growth of limbs from two to four feet in length. They also had a very fine, green, healthy foliage.

To say that I am pleased with the stock would be drawing it mildly. I shall want a few more trees in the spring, and a number of my neighbors want to place their orders with me for their spring stock. I would like your best prices on fruit trees, also berries, currants and other small fruits.

Our peach orchard has been a gnod advertisement for you, and I believe I can make out a large order from here before spring. Just about one year ago I placed my order with a member of your firm in the office at Monroe, and would like to have the same member answer this.

Very respectfully yours,

M. E. ECHTINAW.

I. E. Ilgenfritz' Sons, Monroe Nursery.

Toledo, Ohio, Mar. it, i $8 g 6$.

Gentlemen,-I want some peach trees and some other trees to plant this spring. Will you fill my order at the same price you charged me before? For the last fifteen years I have bought trees of you nearly every year, and always found them true to name, and I never saw better trees. Other nurseries have been after me, but you always used me right, and I want to buy of you.

Yours truly,

PETER RIPPLE

EAST LAKE, MICH., May 4, I899.

I. E. Il.genfritz' Sons, Monrot, Mich ,

Gentlemen:-I send you by this mail Draft for $\$ 172.00$ to pay for the Fruit trees you sent me. I looked the trees over and can truly say they are the finest lot of trees I ever saw. Please accept my thanks for your kind dealing with me and will give you another order for Apple and Pear trees to come next Spring.

Very Respectfully yours, 


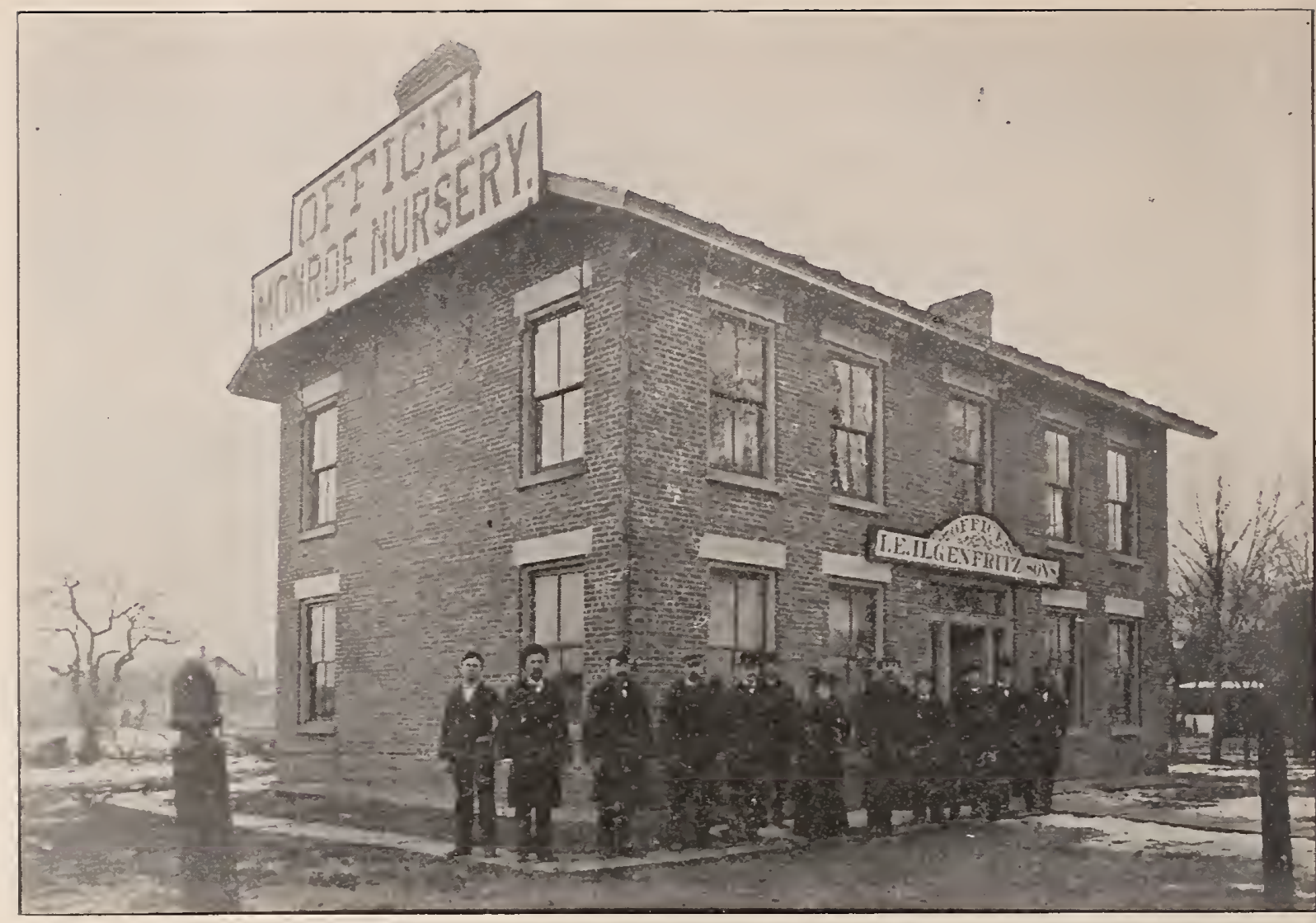

EXTERIOR OF OFFICE.

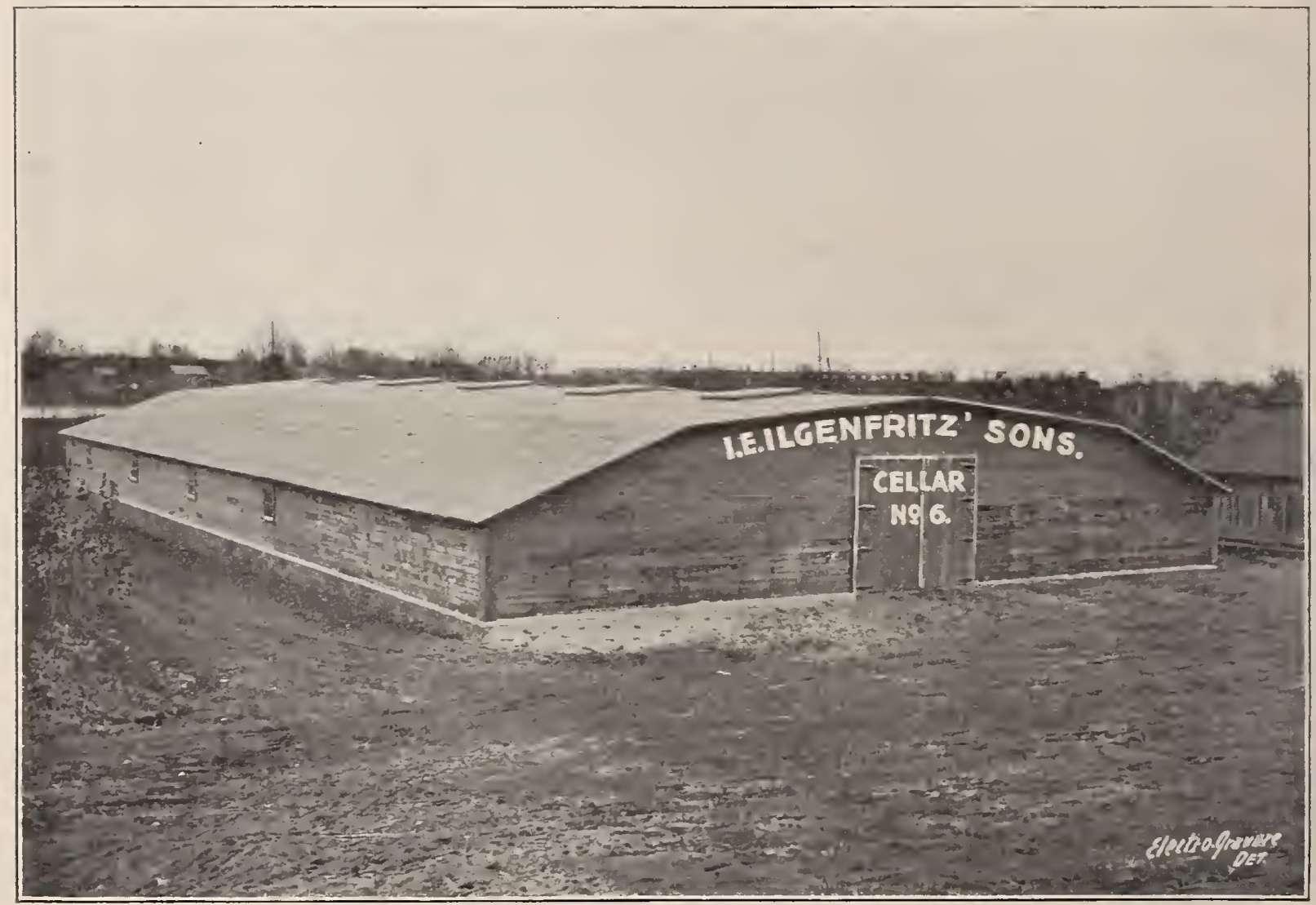

STORAGE CELLAR, No. 6. 


\section{CHERRIES.}

ThE CHERry is one of our most delicious and highly esteemed fruits, and in many parts of the country succeeds admirably.

The class know11 as the Heart and Bigarreau Cherries (rapid growing trees, with large foliage and sweet fruit) do not, however, succeed uniformly as well in all parts of the country. Especially is this true in some parts of the IVest and South, owing to the body of the tree cracking. exuding gun, and often dying outright before it attains a bearing size.

The cause of this difficulty arises chiefly, if not altogether, from the fact that in our ich alluvial soils there is a tendency to over luxuriance in growth. Anything, therefore, that checks this tendency, will be conducive to the longevity and productiveness of this tree.

For the cherry, therefore, we would recommend a light, dry, gravelly soil. Avoid manuring, and do not stimulate the growth by cultivation.

The Duke and Morello classes, easily distinguished from the Heart and Bigarreau by their more spreading and slender branches, smaller growth of foliage, and mostly round shaped, acid fruit, are hardier less liable to crack, and being generally productive are the best for cultivation where the Heart and Bigarreau do not succeed well.

The Early Richmond, a species of the Morello class, has of late years grown in great favor throughout the WVest, as it is considered perfectly hardy, and always very produc. tive. For cooking, drying and preserving, this variety is very valuable.

\section{Heart and Bigarreau Cherries.}

BIACK TARTARIAN.-Very large, purplish black, half tender, mild flavor and pleasant. One of the most popular varieties in all parts of the country. Last of June and beginning of July.

COE'S TRANSPARENT.-Medium size, pale amber, red and mottled next the sun, tender, sweet and fine. Tree vigorous and erect. End of June.

ELKHORN, (Tradescant's Black Heart).--Very large. heart shaped with uneven surfact, skin black, glossy, flesh firm, purplish, good quality. A productive, valuable market sort. Middle of July. One of the best.

GOV. WOOD.--Fruit large, roundish, heart-shaped, light yellow, shaded with bright red, tender, juicy, rich and delicious. Tree vigorous and productive. One of the best sweet cherries, and entitled to a place in every good collection. End of June.

IDA. - Said to be one of the hardiest cherries known. Fruit medium to large, pale yellow, nearly covered with light red, some mottled. flesh tender, juicy and of fine quality. Tree vigorous, upright, abundant and regular bearer. Middle of June.

ROCKPORT BIGARREAU.-Large, pale amber in the shade, light red in the sun; half tender, sweet and good. Middle of June.

WINDSOR. $-v_{N}$ ew, introduced from Canada. Fruit large, liver-colored. resembling the Black Heart. but quite distinct, ripens a few days earlier than that variety, flesh remarkably firm and of fine quality. Tree hardy and very prolific.

SCHMIDT'S BIGARREAU. Large size, rich, deep glossy black, flesh firm, tender, juicy, rich. fine flavor, good shipper. Tree good grower and very productive. A new promising late black variety.

YELLOW SPANISH OR BIGARREAU._Large. pale yellow, with a bright red cheek in the sun. flesh firm, juicy and delicious. End of June.

We have in stock these additional varieties:-

Black Eagle, Cleveland Bigarreau, Elton, Great Bigarreau, Luelling, Napoleon Bigarreau. 


\section{Duke and Morello Cherries.}

DYEHOUSE.-Introduced from Kentucky. Fruit of medium size, bright red and of excellent quality. First of June.

EARLY RICHMOND, (Early May, or Donna Maria).-Medium size, dark red, flesh tender, juicy, rich, somewhat acid. Tree vigorous, profuse bearer, one of the best of its class, unsurpassed for cooking and preserving, the great cherry of the West. Last of May to first of July.

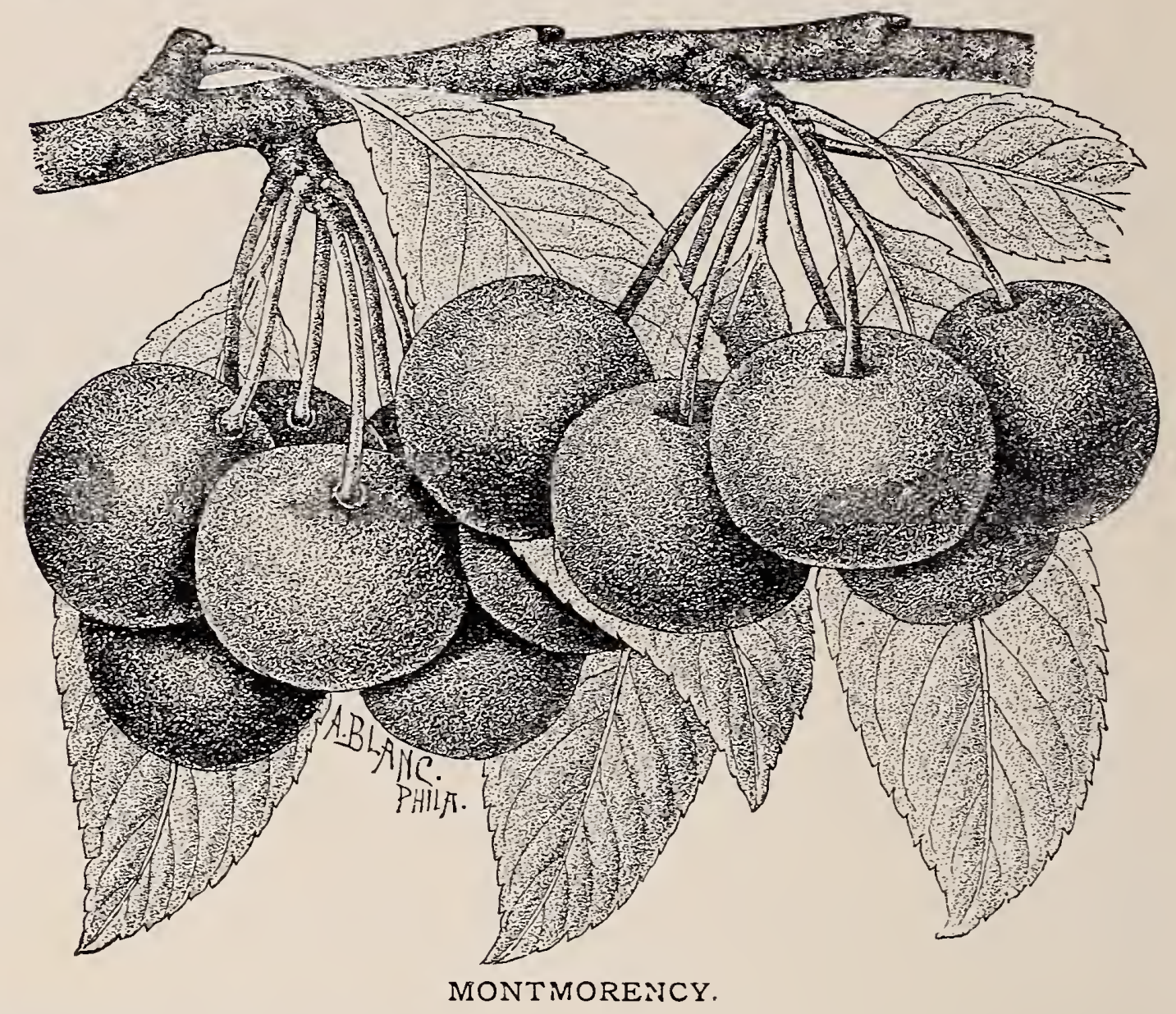

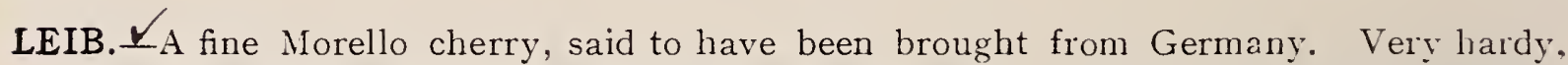
thrifty, upright grower, abundant and regular bearer. Fruit larger than Early Richmond, and ripens about a week later.

MAY DUKE.-An old, well-known, excellent variety, large, dark red, sub-acid, rich. Middle of June.

MORELLO, ENGLISH.-Large, dark red, nearly black, tender, juicy, sub-acid, rich. Last of July and first of August.

MONTMORENCY.-Large, red, rich, acid. Very hardy and productive. A week or ten days later than Early Richmond. A cherry of the Richmond class, but larger anci more solid, strong upright grower. Very valuable. See cut.

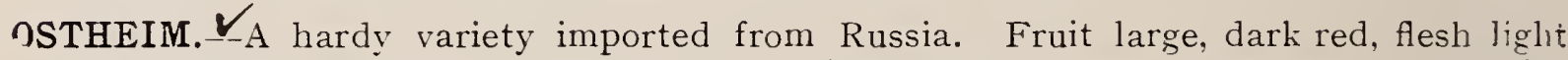
red, tender, juicy, rich, pleasant flavor and very good. Tree moderate grower. Miclतle of July.

$W: ' \imath$ e in stock these additional varieties:-

Arch Duke, Belle de Choisey, Belle de Magnifique, Empress Eugenie, Iate Duke, Louis Philip, Olivet, Plumstone Morello, Reine Hortense, Wragg. 


\section{PLUMS.}

The Plum, a desirable and favorite fruit, hardy and naturally productive, has of late years been much neglected on account of the ravages of the Curculio. This great enemy of the Plum is a small, dark brown insect, less than a quarter of an inch long. It attacks the young fruit soon after the blossoms drop, making a crescent shaped incision, in which it deposits its egg. The fruit thus stung will drop from the tree in about three weeks. It continues its work of destruction for three or four weeks longer.

The most practical method of checking their. depredations is by jarring them off the tree. The best time to do this is early in the morning, while the insect is in a partially torpid state from the effects of the cold. Procure a white sheet of cotton cloth; spread it under the tree as far as the branches extend, then by giving the tree a sudden jar with a mallet or some other instrument, they will drop upon the sheet, when they are easily gathered and destroyed. To avoid bruising the tree, a good plan is to saw a limb off an inch or more from the trunk, on which to strike. The jar must be sudden or they will not be dislodged. This operation must be repeated daily for the period of a month or more, or until the fruit has nearly attained its full size. A considerable number of trees may thus be tended, and the trouble and expense is small in comparison with the value of the crop. The soil best suited to the Plum is a rich loam inclined to clay, but it will adapt itself to a variety of soils.

Extra select trees 5 to $7 \mathrm{ft}$.

BRADSHAW.-A very large and fine early plum, dark violet red, juicy and good. Tree vigorous, erect and productive. A valuable market variety. One of the best. Mid. dle of August.

BEAUTY OF NAPLES.-A new variety of much promise. Size large; greenish yellow color; flesh firm, juicy and very fine flavored. Tree very hardy and productive. September.

GERMAN PRUNE. (Quetsche)—Large, oval, purple or blue; juicy, rich, fine. September.

GREEN GAGE BAVAY'S.-(Reine Claude de Bavay)-Medium size; roundish, oval; skin greenish yellow, marked with red in the sun; flesh yellow, juicy, and of excellent flavor. Tree a good grower and productive. Last of September.

GEUII.-A new variety regarded very valuable for market. Fruit very large, deep bluish purple, covered with thick bloom; flesh yellowish green, coarse, sweet and pleasant. Tree strong grower, hardy, and an early and great bearer. September.

IMPERIAL GAGE.-Large, oval, greenish; flesh juicy, rich, delicious. Middle of August.

LOMBARD.-Medium size, oval, violet red, flesh yellow, juicy and pleasant. A great bearer, and peculiarly adapted to light soils. Tree vigorous and hardy, succeeds when most other varieties fail. The most popular and profitable plum under general cultivation. Last of August.

MOORE'S ARCTIC.--A new hardy variety, which originated in Maine, of medium size or below, skin dark purplish black, with a thin blue bloom, flesh greenish yellow, a little coarse, juicy, sweet. Tree vigorous, an early and prolific bearer. Last of September.

POND'S SEEDLLNG.-A magnificent English variety. Fruit very large, oval, skin light violet red, flesh coarse, juicy and sugary. Tree a vigorous grower and niost abund. ant bearer. One of the most attractive plums cultivated. Ripens in September. 
SHIPPER'S PRIDE.-Large size, dark purple, handsome, showy, flesh firm and excellent. Promises to be a superior market sort. Tree very hardy and productive. Fore part of September.

STANTON.-Medium to large, dark purple overspread with a beautiful bloom. Very productive and valuable for its keeping qualities. When ripe skin peels off like a peach, making a most delicious fruit for camning. The meat is solid and rich, with very small pit. An excellent shipping variety; always brings top price in market. Ripens a little later than most other varieties.

YELLOW EGG. (Yellow Magnum Bonum) - Fruit of the very largest size, oval, skin yellow, with numerous white dots, rather coarse, sub-acid, fine for cooking. J,ast of August.

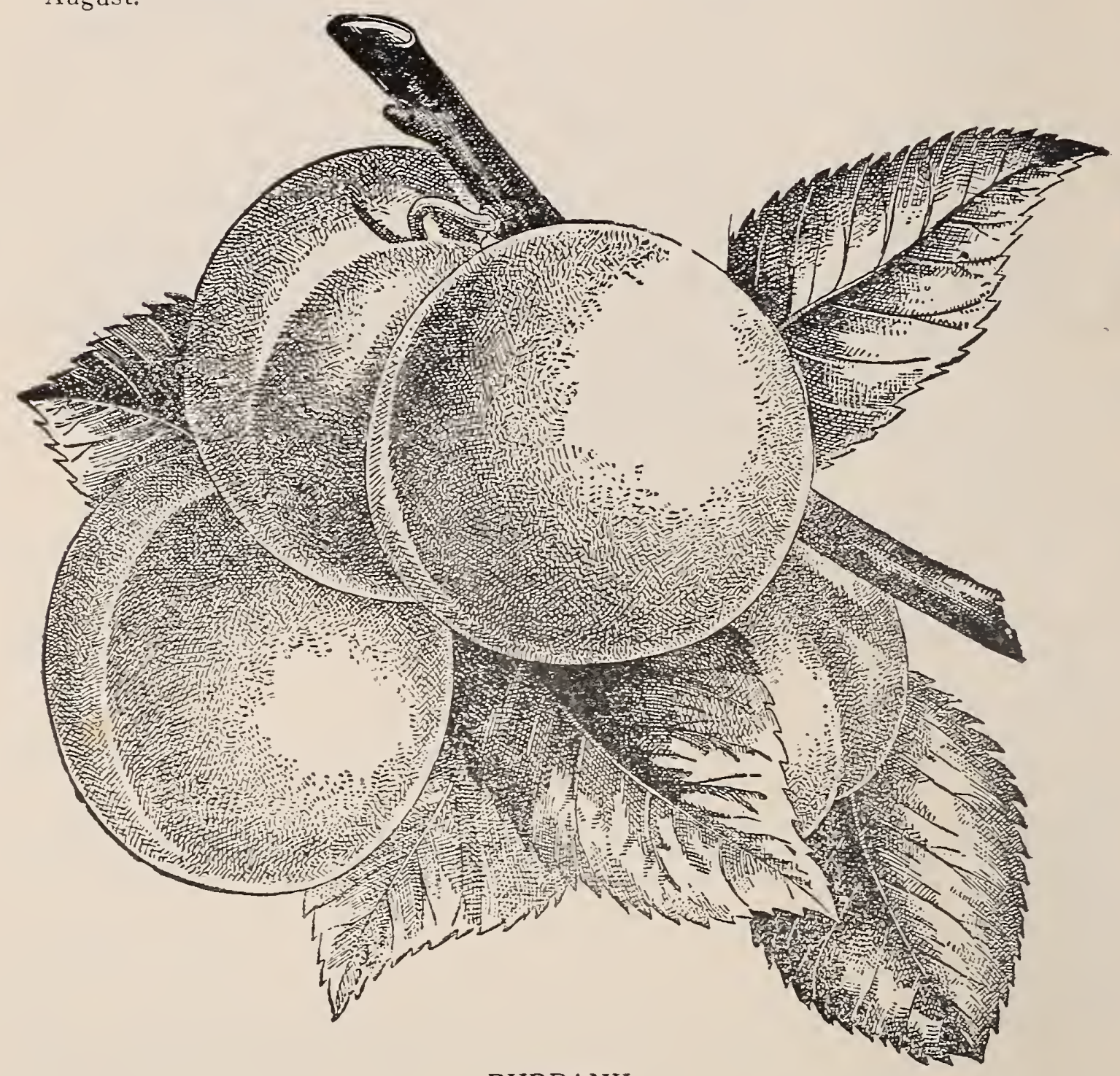

BURBANK.

We have in stock these additional varieties:-

Coe's Golden Drop, Duane's Purple, Fellenberg, General Hand, Jefferson, Lawrence Favorite, McLaughlin, Monroe, Peach, Prince Englebert, Quackenboss, Red Magnum Bonum Shropshire Damson, Smith's Orleans, Saratoga, Spaulding, Washingtull, Yellow Gage. 


\section{Asiatic Varieties.}

Becoming the most popular plums in this country. It is predicted they will, in the near future, be the leading " all purpose" plums grown here.

ABUNDANCE. (Botan)-Large to very large, oblong, amber, nearly covered witl bright red and orerspread with a thick bloom, flesh orange yellow, juicy, melting, and of delicious sweetness, stone small and flesh readily parts from it. Tree strong grower and an early and profuse bearer. Ripens in advance of other Plums. Valuable for canning and market. This variety has attracted much attention throughout the country, and is very highly recommended.

BURBANK.-The Burbank Plum stands at the head of the celebrated Japanese varieties. It is proving remarkably successful the country over. No other pluin ever became so popular in so short a time. This is because it is practically curculio proof, and is very free from black knot. It has been fruited from 7 to 9 years in this country, an $\bar{\alpha}$ is perfectly hardy (said to stand zo degrees below zero), ripens in August. It seems to succeed on any soil, sand, clay, or loam. It can be picked green, and will ripen and color up perfectly, and will not lose its flavor. Will keep fully two weeks in perfect condition after ripening. Abundant yearly bearer, fruit large, roundish, dark red or purplish, with thin lilac bloom, flesh amber yellow, melting, juicy, with rich sugary flavor, stone small and free, bears second year after planting.

STRAWBERRY. - A dwarf variety of the same family as the DeSota and IVild Goose. An early bearer; fruit bright red varying in size from three quarters to one and one quarter inches in diameter.

WILLARD.-One of the imported Japanese varieties. Ripens early, very hardy and productive, a long keeper and not inclined to decay. Similar to Abundance in color.

We have in stock these additional varieties:-

Ogon, Prunis Simoni, Prunis Pissardi, Satsuma, Strawberry, Wixom.

\section{Improved Native Varieties}

THAT SUCCEED WELL WORKED ON PEACH STOCK.

WILD GOOSE.-An improved variety of the Wild or Chickasaw Plum. Fruit of medium size, bright red, very handsome, productive, and valued for cooking and market, as it ripens early: is valuable in localities where the choice plums do not thrive.

WEAVER. - A wild plum of fiue size, good flavor, very hardy and productive, and nf much value in a severe climate, where choice, cultivated plums do not succeed.

We have in stock these additional varieties-

Blackman, De Soto, Marianna, Richland.

I. E. Il,GENFritz' SONS, MonroE, Mich.,

North Byron, IICH., Nov. 2, IS99.

Dear Sirs:-As I have not seen your Agent since early summer I have not had the chance to order with him.

I want you to send me next Spring 25 Crosby Peach trees. Our trees we ordered last year from you were very nice trees and as long as you send us as nice a lot of trees as we have had in the past, we will place our fruit tree orders with you.

Yours very truly,

Mirs. Eillan JUdSON. 


\section{APRICOTS.}

THE APRICOT is one of the most delicious of our dessert fruits. It ripens between Cherries and Plums. The remarks on the Curculio, under the head of Plums, are applicable to the Apricot. The tree may be trained on walls, but a northern or western exposure is better. It is recommended to shorten in the limbs of the Apricot, as was remarked also of the Peach.

EARLY GOLDEN. (Dubois Early Golden) $\checkmark$ Fruit small, roundish oval, pale orange color, flesh yellow, moderately rich and sweet. Tree vigorous with long slender branches. Middle of July.

MOORPARK.-One of the largest and finest Apricots, yellow with a red cheek, flesh orange, sweet, juicy and rich, parts from the stone. Very productive.

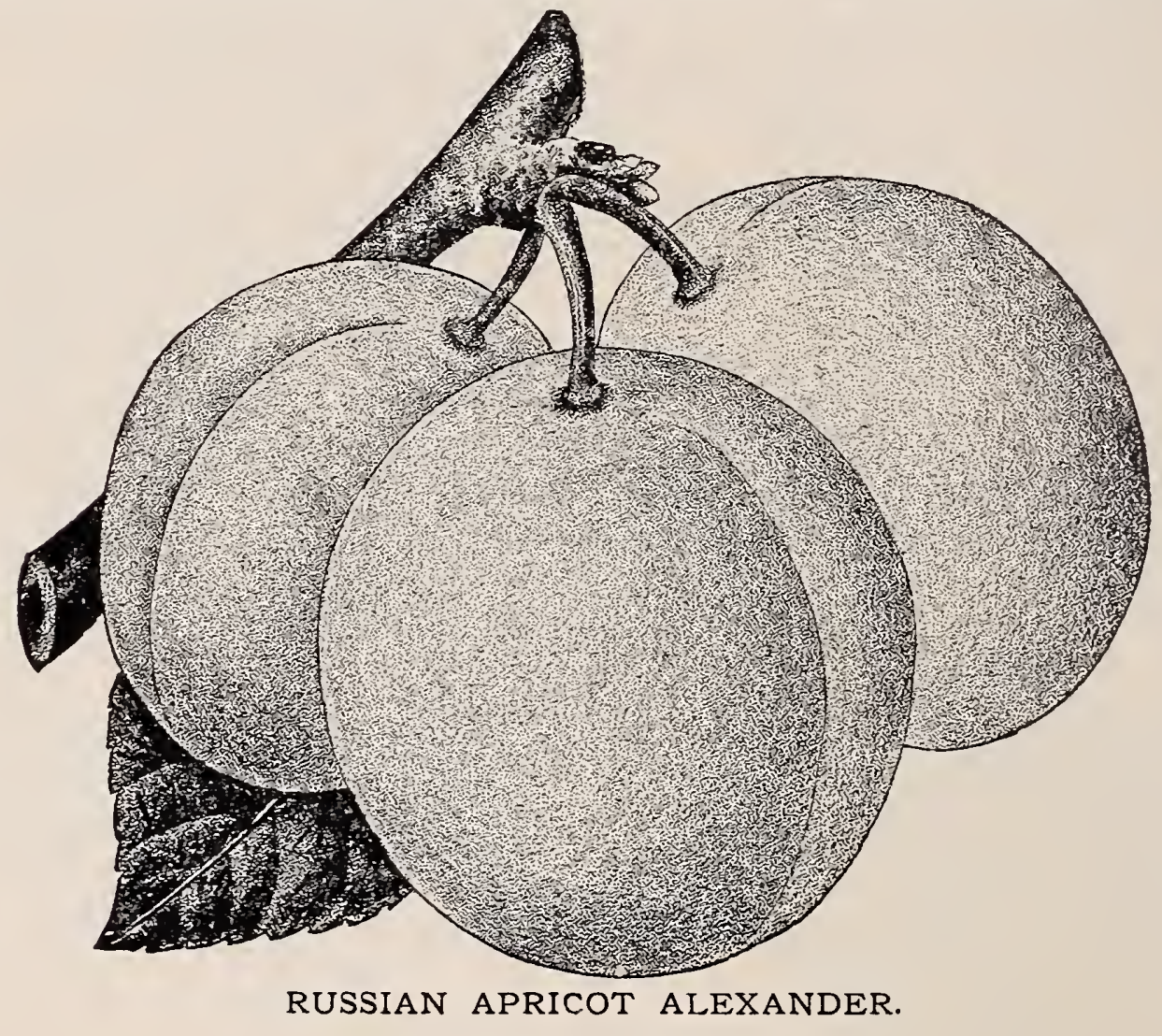

Russian Varieties.

ALEXANDER.-Fruit large, oblong, yellow flecked with red, both skin and flesh, Havor sweet, delicious. Tree hardy and immensely productive. One of the very best. First of July.

J. L. BUDD.--Tree hardy, strong grower ani profuse bearer. Fruit large size, whıte with red cheek, flesh juicy, sweet and excellent. Kernel as fine flavored as an almond. A decided acquisition, and considered the best variety. First of August.

We have in stock these additional varieties:-

Native Varieties:-Breda, Large Early, Peach, Roman, St. Ambrose.

Russian Varieties:-Alexis, Catherine, Gibb, Nicholas. 


\section{NECTARINES.}

The Nectarine requires the same culture and management as the Peach. from which it differs only in having a smooth skin, like the Plum. It is extremely liable to attacks from the Curculio, and needs the same remedy as recommended for the Plum.

BOSTON.--Fruit large and handsome.

ELRUGE.--Medium size, greenish yellow, witl a dark red cheek, flesh greenish white, juicy and high flavored, excellent. Beginning of September.

RED ROMAN.--Greenish yellow and red, rich and good. September.

HUNT'S TAWNY.-Medium size, pale orange, with a mottled red cheek, flesh juicy, melting, rich and good.

Farmington, Mich., Feb. 27 th.

Gentlemen,--I write to inform you that I am much pleased with the first year's growth of trees that I purchased last spring. The trees were received in first class condition, and choice stock. Out of the 450 plum, 300 peach, and 200 pear trees that I received, I lost only 4 trees. All those here who received trees from your nursery last spring are well satisfied and want more.

Very respectfully,

C. WV. BOTSFORD.

Mears, Mich., Fer. 2 d.

Gentlemen,-In the spring of ' 9 o I' set out 450 peach trees from your nursery: at the same time I ordered two other varieties which you informed me you could not furnish. I was anxious to get those and no other, so ordered from an eastern firm, and that Ioo trees are a detriment to my orchard, not true to name at all. The ones I received from you people without an exception are true to name.

Very respectfully yours, GEO. WYKOFF.

Plymouth, Mich., April 28th.

Gentlemen,- The trees arrived here in good shape. I have delivered them according to your orders, and have received payment in full on each order. Everything is all O. K. Yours respectfully,

JOHN LUTY, Merchant.

HARBOR SPRINGS, Mich., OCt. 2 oth.

Gentlemen,- Your trees and strawberry plants arrived here promptly and are now planted. I wish to tell you that I am entirely satisfied with the trees as well as the plants. They came in excellent condition. Please find enclosed money order for \$40.Io to pay for them. Very respectfully yours,

A. F. MELCHINS.

Farmington, Mich., Feb. 20th.

Gentlemen,- I wish to inform you that I am well pleased with the trees that I purchased of you last spring. They are looking well, and I think they will make good, healthy trees.

Very respectfully,

THOMAS MCGEE.

Roscommon, Mich., April zoth.

Gentlemen,- Please send me your price list of nursery stock and oblige me. I bought of you my first orchard when I lived in Lenawee county, in the Township of Riga, 1858. 


\section{QUINCES.}

The Quince is a most estimable fruit for preserves, and especially fine for jellies. It commands a high price in the market. It should be planted in a rich, mellow and moist soil, about ten feet apart.

APPLE OR ORANGE.--Large, roundish, bright golden yellow. Very productive and most desirable variety. Ripens in October.

CHAMPION.--Large to very large, oblong, skin russeted about the stem, and of a bright yellow color, flesh tender and of good quality. Tree an early bearer and very prolific. Ripens about two weeks after the Orange Quince.

MEECH'S PROLIFIC.-A new variety, said to be larger than the Orange, and similar to Champion in shape, of great beauty and delightful fragrance. Tree very vigorous and productive. Ripens early.

REA'S SEEDLING. -Very large, rich yellow. A seedling of the Orange Quince. Strong grower and productive.

St. Ignace, Mich., April 3oth.

Gentlemen,-Yours of the 3Ist ult. received. The order to your agent is all right. I have set three orchards from your company; one nearly thirty years ago.

P. S. Amount of above order, \$175.

Respectfully yours,

E. B. CHAMBERLAIN.

Tekonsha, Mich., April 26th.

Gentlemen,-Find enclosed draft for \$172.38. Fruit trees came in fine order.

Yours respectfully,

W. L. MAIN.

Shelby, Mich., APril 25th.

Gentlemen,- I received my trees in good condition. They are very nice, too. Please accept thanks for the same.

Yours respectfully,

F. M. MYERS.

Brevort, Mackinaw Co., Mich., May 5, i894.

Gentlemen,- The trees I got of you last year are all alive. One of them last year bore. three apples. Yours truly,

GEO. A. VAUGHT.

Eau Claire, Wis., April 3oth.

Gentlemen,-Those shrubs came yesterday, and they were in excellent condition and as nice as I ever saw. Many thanks. Enclosed find express order in payment.

Yours respectfully,

DR. H. R. CURTISS.

Watervale, Mich., JaN. 30th, i 895.

Gentlemen,- I am well satisfied with your trees so far, and hope you will favor me with some nice trees the coming spring. The Ioo peach trees that I got of you in the spring. of I8gI bore last season, and are pronounced very fine by all who see them.

Respectfully,

J. H. HOWARD. 


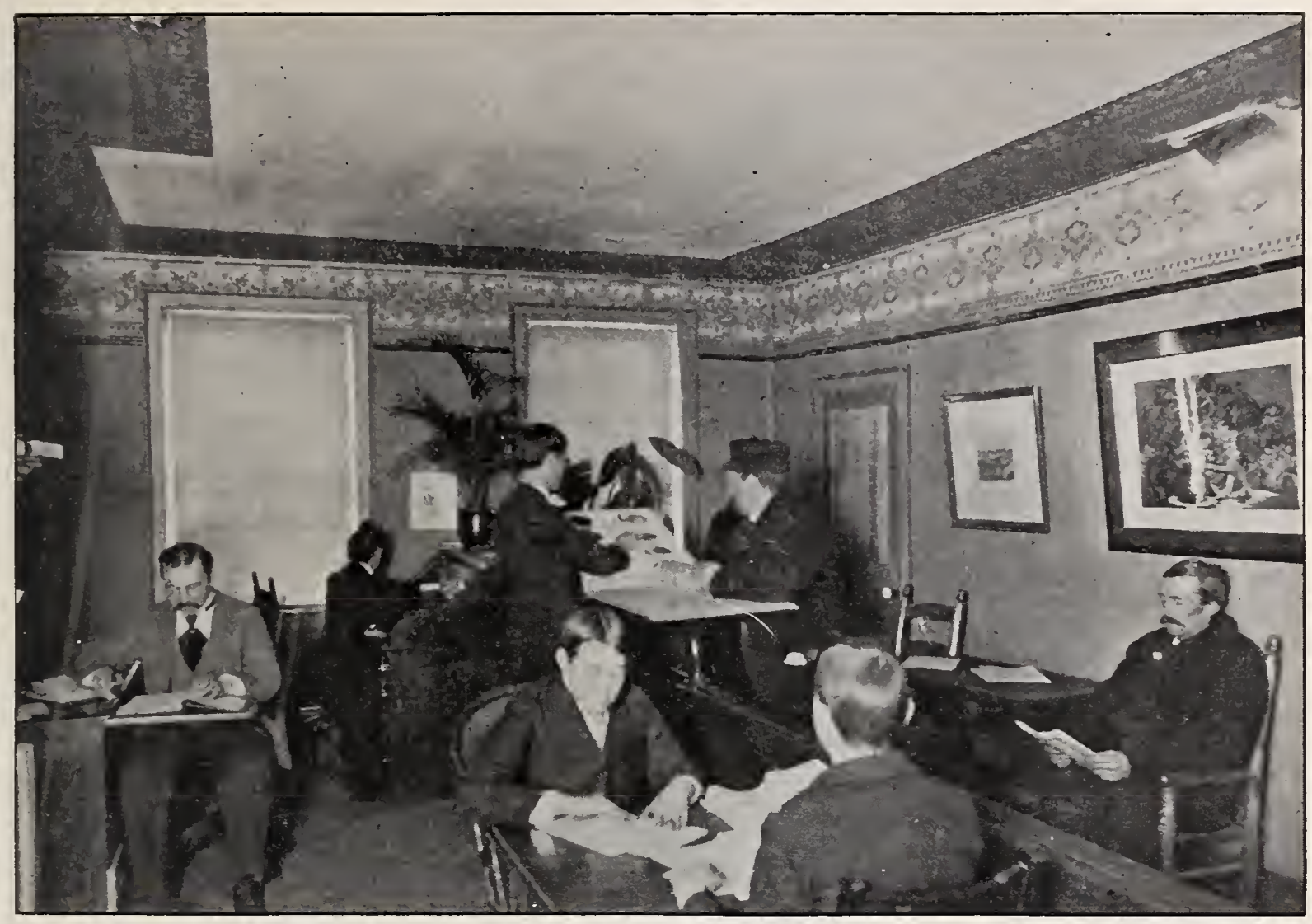

GENERAL OFFICE. ROOM 1.

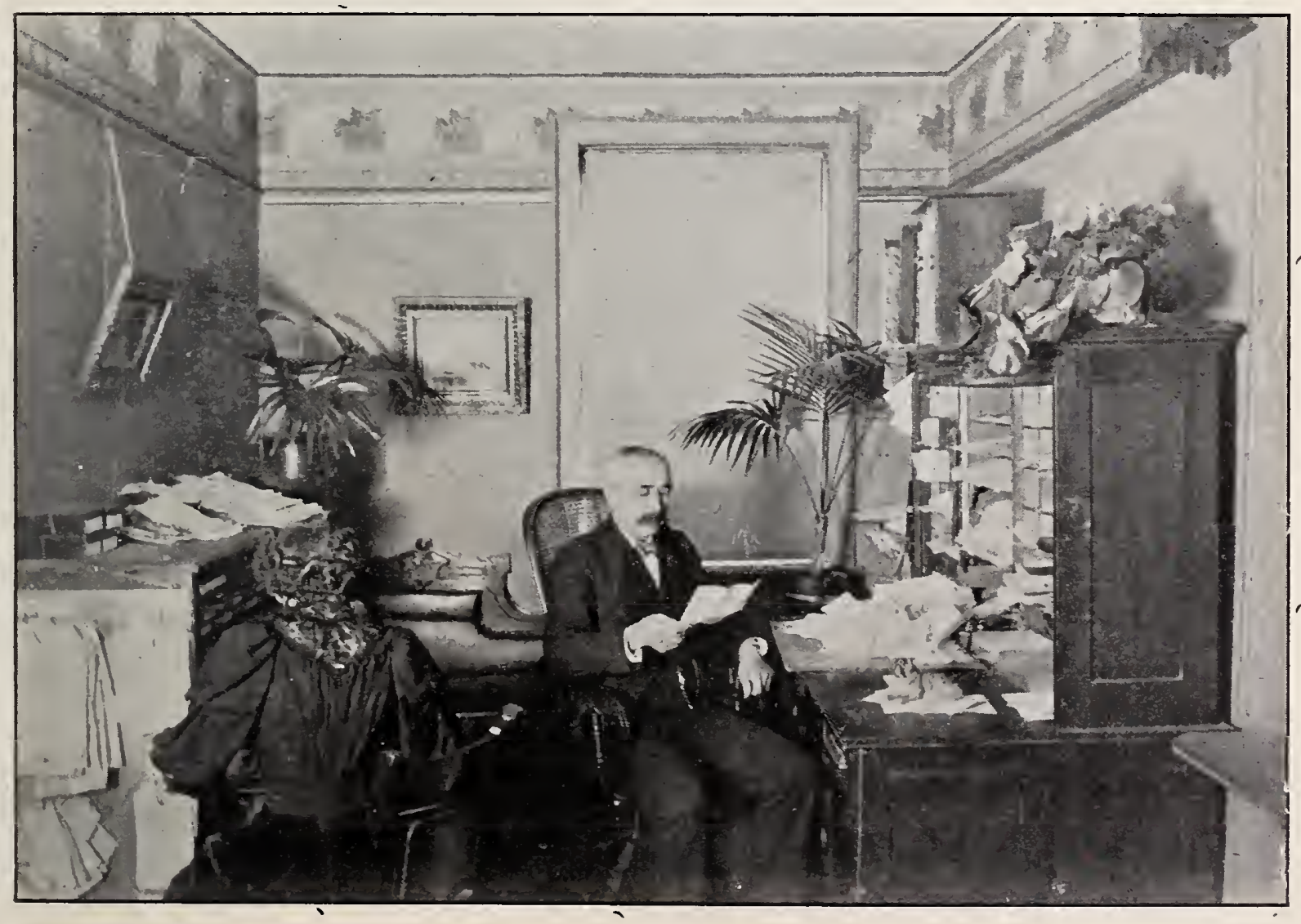

PRIVATE OFFICE. Room 3. 


\section{GRAPES.}

THE culture of the grape within the last few years has attracted a great deal of attention throughout the United States. Many vineyards of large extent have been and are still being planted in various parts of the country, and are proving a great pecuniary success.

While some make this branch of Horticulture a specialty from pecuniary motives, every one owning a garden spot should devote a portion of it to a few of the best varieties.

\section{Black Varieties.}

CHAMPION. (Talman)-Bunches medium to large, compact, berries large, black and adhere to the stem, skin thick and firm, flesh sweet, juicy, somewhat pulpy, vigorous. hardy and very productive.

CONCORD.-One of the best, well tried, native grapes. It is of very large size, both of bunch and berry, quality good, color black, covered with a thick bluish bloonı, flesh moderately juicy, rather buttery, very sweet. It is perfectly hardy, vigorous in its habits of growth, very healthy and very productive. Ripens two weeks earlier than the Isabella. We think there is no grape which has given so universal satisfaction as this, and it is constantly increasing in public favor as the variety grows older. No family should be without it.

EARLY OHI0.-A new black grape, its points of merit are extreme earliness, hardiness, productiveness and being of better quality than most early sorts. Berries large, firm, of spicy, pleasant flavor, hangs to the stem with a persistency that makes its shipping qualities of the highest order. Ripens about three weeks before the Concord. Promises to be valuable as an early market sort, and also desirable for garden culture.

MOORE'S EARLY.-A $\$ 60$ prize grape of the Massachusetts Horticultural Society. Promises to be a valuable acquisition. Berry very large, black, bunch medium. quality very good. Ten days earlier than Concord.

WORDEN.-Promises to be very popular. Bunch large, shouldered and handsome, berry large, black, skin thin, flesh sweet much like the Concord, and ripens a few days earlier. Vine hardy, vigorous and productive.

\section{Red or Amber Varieties.}

AGAWAM. (Roger's No. I5)-A dark red grape of the Hamburg cross. Bunches large, compact, frequently shouldered, berries large, with a thick skin, pulp soft, sweet, sprightly, vine very vigorous. Ripens early.

BRIGHTON.-A valuable variety, possessing much of the excellent flavor of the famous Hamburgs, and also the hardiness of our best native sorts. The berry is large, resembling the Catawba, and ripens with the earlier varieties. 


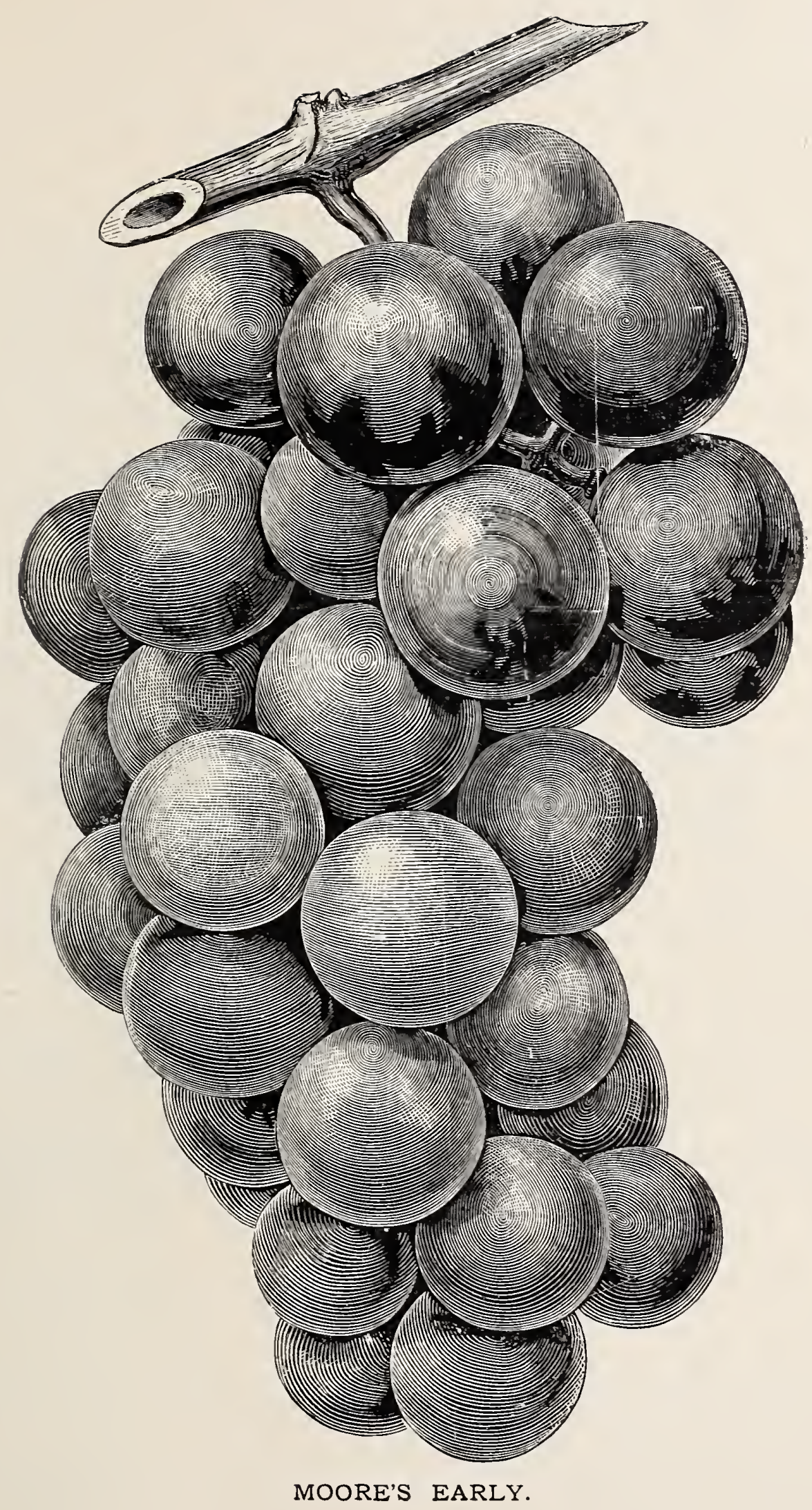


DELAWARE.-This fruit has fully maintained its high reputation as one of the finest of our native grapes. The vine is comparatively slender, but grows freely. It proves quite hardy in this climate, and ripens two or three weeks before the Isabella. Bunch small and compact, berries small, clear, red, beautiful, sweet, sugary and vinous, with a musky aroma equal to the finest foreign varieties. It justly claims a place in every garden.

MOYER.-A new grape, originated in Canada. In habit of growth, hardiness, quality and size of cluster it resembles the Delaware very much, but ripens earlier, has larger berries, and has been free from rot and mildew. Flavor sweet, delicious and free from foxiness. Skin tough but thin, pulp tender and juicy. Its shipping qualities are excellent.

SALEM.-(Rogers' No. 22)--Described by Mr. Rogers as the best of his seedlings. Bunch and berry large, of a light chestnut color, flavor sweet and sprightly. As early as Hartford Prolific or Delaware.

\section{White Varieties.}

GREEN MOUNTAIN.-(Winchell)--Greenish white, skin very thin, pulp exceedingly tender and sweet. Vine strong grower, hardy and productive. Originated in the mountains of Vermont. Quality extra, and promises to take front rank for garden and vineyard culture. Ripens very early, about two to three weeks before Concord.

LADY WASHINGTON.-A desirable seedling of Rickett's. Bunch large to very large, moderately compact, berry medium, skin pale yellow with a tinge of pale pink in the sun. Ripens soon after Concord.

MOORE'S DIAMOND.-Originated by Jacob Moore, the producer of the Brighton, and seems destined to become very popular, equal in size to Concord, color greenish white with a rich yellow tinge when fully ripe, flesh tender, juicy, nearly transparent and very good, vine vigorous, hardy and productive. Ripens two weeks before Concord.

NIAGARA. - This white grape has attracted the most attention of any new fruit recently introduced. The vine is a strong grower, healthy and prolific, bunches large, uniform and compact, berry large, skin greenish white, slightly ambered in the sun, quality good. Ripens with Concord.

POCKLINGTON.-A showy, white variety of good quality, vine very hardy, healthy and productive. It is a seedling of Concord. Will no doubt prove a valuable and popular grape. Ripens soon after the Concord.

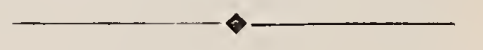

I. E. Ilgenfritz' SoNs,

Pontiac, Mich., Jan, 30th, I895.

Gentlemen, - Yours of the 29 th received and contents noted. You can book my order at your price, and I will let you know when to ship the trees. They are to fill out and square. the blocks already set. The trees I received of you in 1893 are the finest lot that I ever saw for the number, and so admired by everyone that has seen them. Out of the 4,000 peach trees, all in one block, I lost but seven trees the first year. Last year was very dry, and we lost but a few trees. Those I received of you last year (I894) I lost but two pear trees. I think this is doing remarkably for 700 pears and 300 peach trees, and a very dry summer to contend with. If you hear of anyone doing better from any nursery, I would like to hear from them. I wish you would come and see them for yourself. If you will come next summer, I will have a photo taken of the orchard, thirty acres, all in one block. I remain Yours truly, 


\section{CURRANTS.}

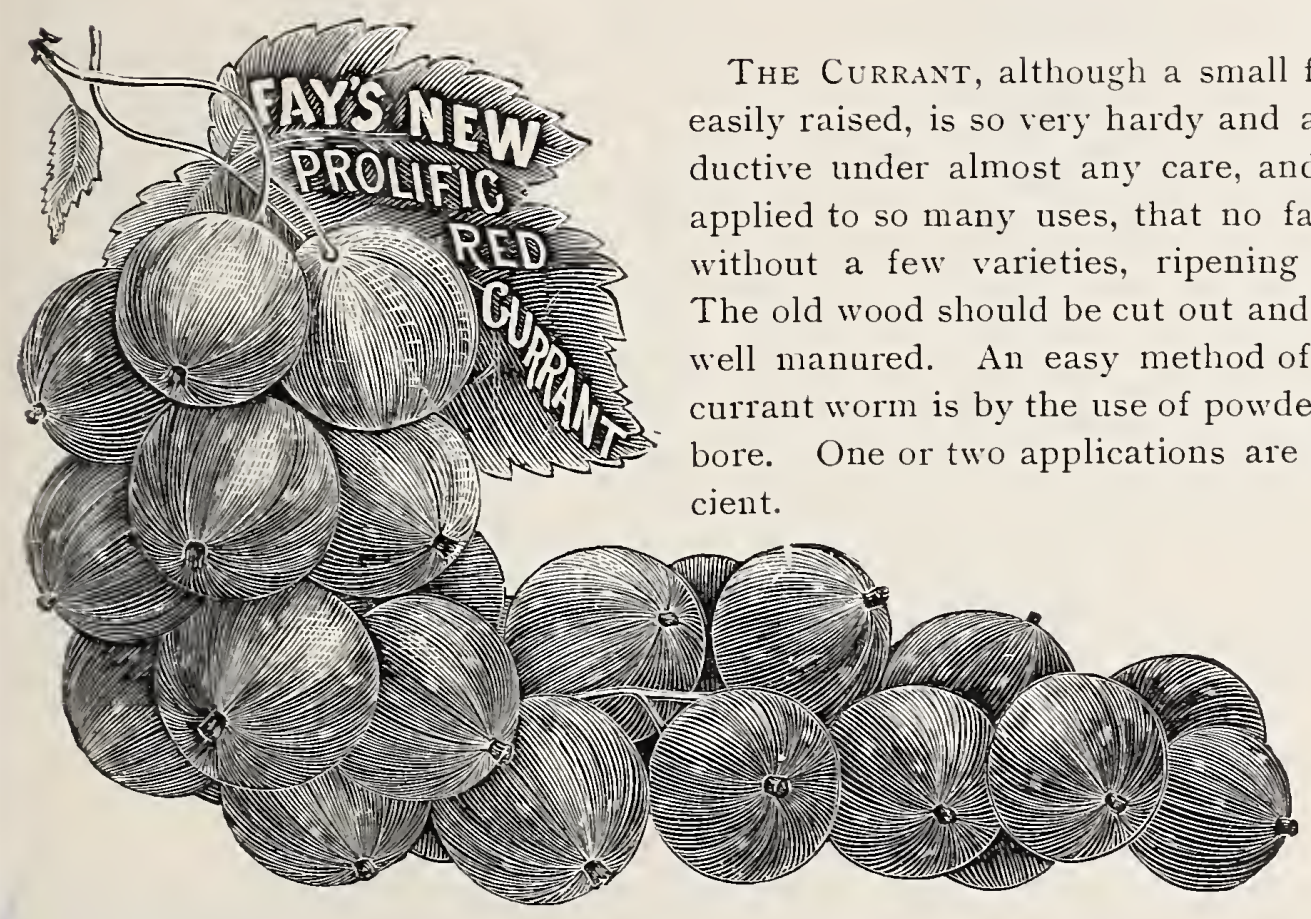

BLACK CHAMPION. - Recently introduced from England, and wherever tested pro. nounced the best black sort grown. Bunch and berry very large, quality excellent, Strong, vigorous grower and very productivs

CHERRY.-One of the largest of the red currants. bunches very short, plants vigorous and productive. One of the best.

FAY'S PROLIFIC.-A new variety produced by crossing the Cherry and Victoria, and is a valuable acquisition. Fruit very large, bunch long and plant rery oroductive. $\therefore \cdots \cdots$

LA VERSAILLAISE.-A French variety. Very large, deep red, long bunches, beautiful and verv productive.

VICTORIA._Very large, bright red, bunches very iong, late productive and valuable,

WHITE GRAPE.--A very large variety. Plant quite distinct from the other white varieties. A great bearer. Should be in every collection.

We have in stock these additional varieties:-

Black Naples, Crandall, Lee's Black Prolific, North Star, Prince Albert, Red Dutch, Red Grape, White Dutch, White Gondoin. 


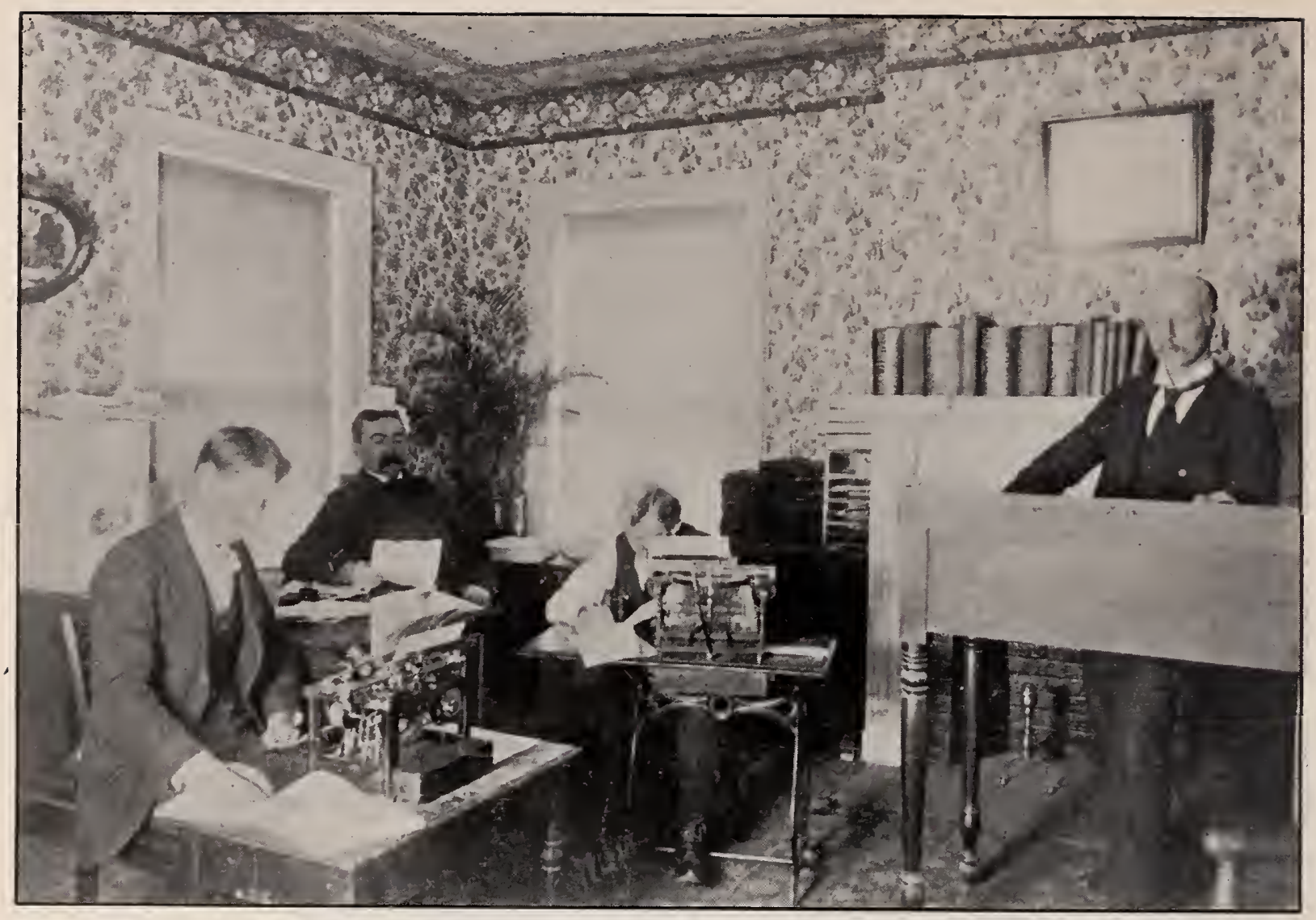

AGENCY DEPARTMENT-ROOM 5.

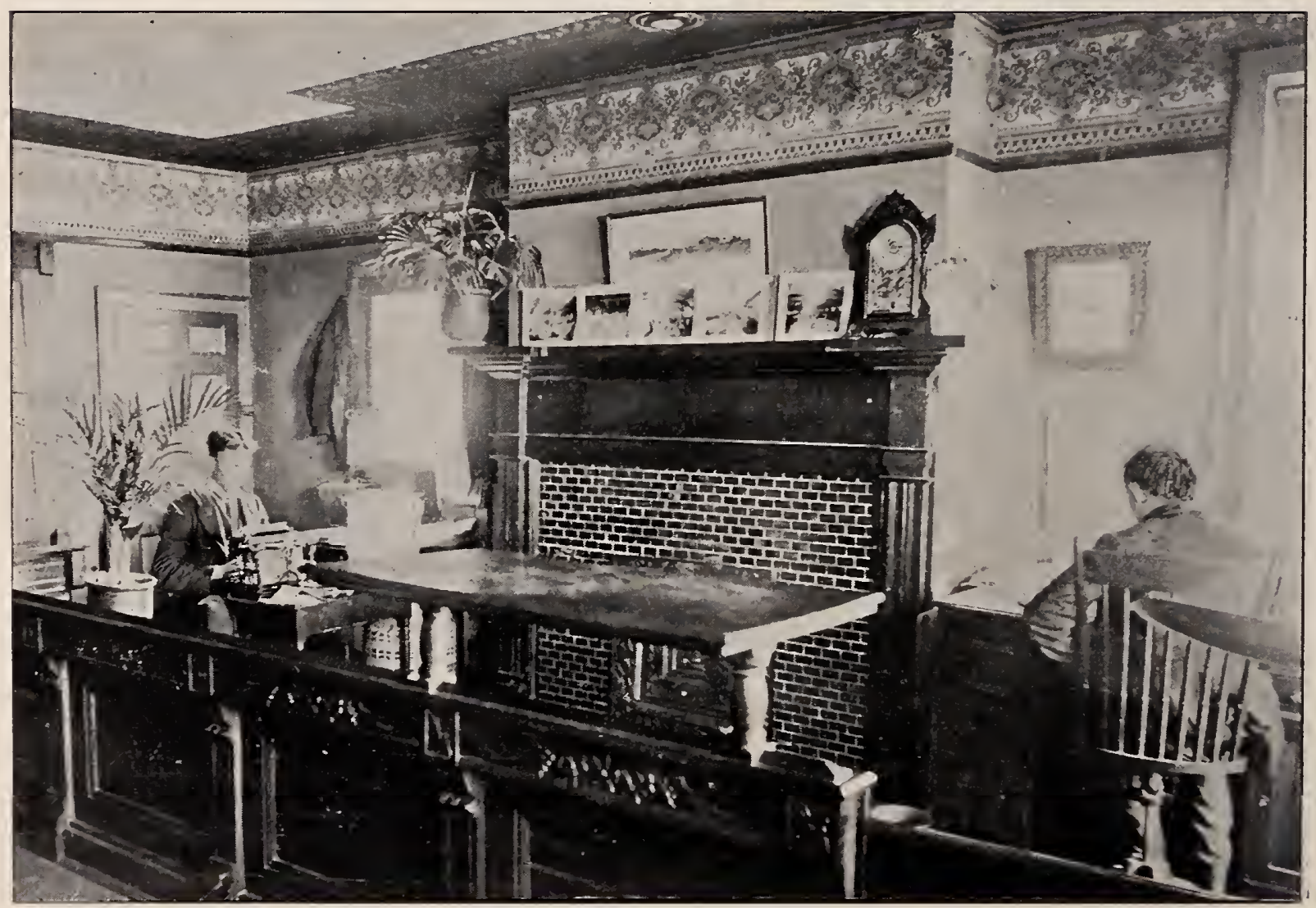

COLLECTION DEPARTMENT. 


\section{RASPBERRIES.}

i His refreshing and excellent fruit should have a place in every garden. In order to keep a bed in good condition, the old and dead wood should be cut out as soon as the crop is gathered. The ground should be well spaded and a top dressing of manure put on.

\section{Red Varieties.}

CUTHBERT. (Queen of the Market)--Considered by many the most valuable red berry for market, also one of the best for home use, fruit medium to large, rich crimson, very handsome, quite firm, juicy, sweet, very good, hardy and productive. Should be in every garden. We have grown many acres of this variety, and always found them profitable. See cut.

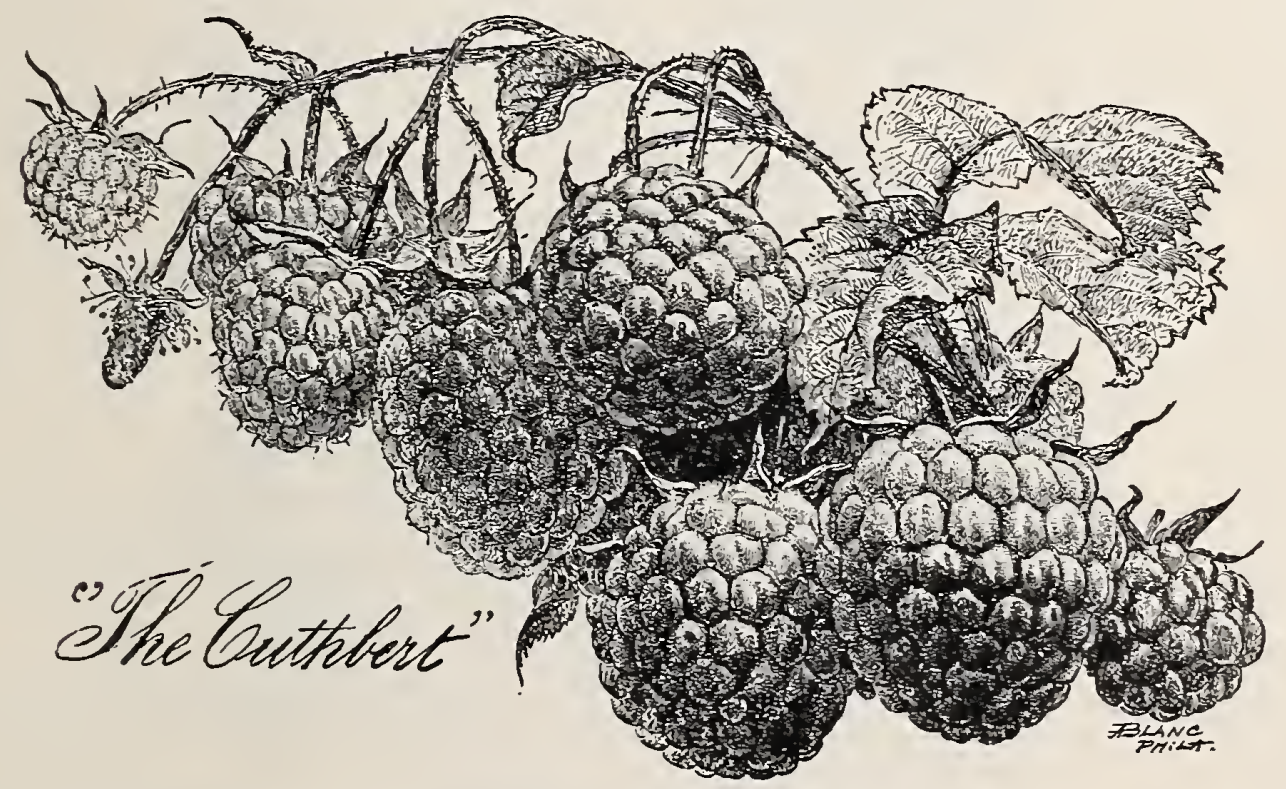

JAPANESE RASPBERRY OR WINEBERRY._Berry medium size, round, bright red, sparkling and attractive. Borne in clusters, and each berry at first tightly enveloped by a large calyx forming a sort of burr, which is covered with purplish red hairs, these gradually open and turn back, exposing the fruit. The canes are covered with purplish red hairs, the leaves are large, thick, dark green above and silvery gray beneath. A novelty particularly of ornamental value; some regard the fruit as good.

LOUDON. $V_{\mathrm{A}}$ new variety, originated in Wisconsin, and it is claimed that it is a berry far superior to the Cuthbert, which is saying a great deal for it. It is a vigorous grower. The fruit is large, beautiful, rich, dark crimson color, good quality and marvelously productive, very hardy, withstanding cold winters without protection and without injury to the tips. It stands shipping better than any other variety, and will remain on the bushes longer without injury. It promises to lead all other profitable red market varieties. The Rural New Yorker says: "Likely to supersede the Cuthbert, more vigorous, perfectly hardy, averages larger, adheres well to the stem, never crumbles, bright red, darker when dead ripe." 
GOLDEN QUEEN.--New yellow variety of recent introduction, supposed to be a seedling of the Cuthbert, which it resembles in all respects except color, being of a rich, bright creamy yellow. Promises to be a valuable acquisition.

\section{Black Cap Varieties.}

EARHART EVERBEARING. This is considered by some the best everbearing raspberry yet introduced. Fruit large size, jet black, good quality. Strong stocky grower, hardy. Ripens ro days earlier than Gregg and continues to bloom and produce fruit until stopped by the frost.

GREGG.- This is one of the very largest of the black caps. It is a hardy strong grower and very productive, fruit firm, juicy, sweet, rich and very good. Valuable market variety.

GAULT PERPETUAL. $レ$ (Everbearing).--One of the greatest novelties ever introduced in the line of small fruits. It ripens a large crop at the time of Gregg, producing more fruit, and continues bearing on young wood until killed by frost. This does not mean a few berries after the first crop is over, but large clusters, containing sometimes as high as 80 to roo to a single cane. It does not exhaust the vitality of the wood, for the same cane will bear the next season. Berries, large, black, firm, of fine flavor. This variety has been tested for several years, and found to be very valuable.

KANSAS.--Originated at Lawrence, Kansas, where it has proven itself the best of all Black Caps. Berries larger than Gregg, jet black, almost free from bloom, juicy and of excellent flavor, firm and carries well. Canes very vigorous, hardy and exceedingly productive. Ripens a little ahead of Gregg.

PALMER.-A new early Black Cap of extreme hardiness. Fruit of large size and good quality. Wonderfully productive, often bending the canes to the ground under the weight of fruit.

We have in stock these additional varieties:-

Conrath, Doolittle, Hilborn, Johnson's Sweet, Marlboro, Mammoth Cluster, Ohio, Souhegan, Shaffer's Colossal, Strawberry-Raspberry, Columbian.

MilWaUkeE, Wis., MAY 7 th, I 896.

Dear Sirs,-Received your boxes of evergreens, and am more than satisfied with the quality of the same, as well as with the prices and packing.

Yours truly,

CHAS. NIECKENHALSER.

Delaware, Ohio, MaY ist, i8g6.

Gentlemen,-1 have pleasure in enclosing you the amount of your bill, The trees came in good condition, were fine stock, and entirely satisfactory.

Very truly yours,

GEO. W. CAMPBELL.

Grand Rapids, Mich., May iIth, i 896.

Dear Sirs, - The stock purchased from you for this spring's planting arrived in excelient condition, even better than that purchased for ' 95 , which was good. I shall wish to nlace a small order with you for ' 97 . Please send me a catalogue, and oblige,

Yours very respectfully,

A. R. HARRINGTON 


\section{BLACKBERRIES.}

THERE should be in every collection a few plants of this delicious and healthy fruit, as it requires but little care and expense, and is an excellent table fruit. The plants should be set from four to six feet apart in a moderately rich soil. Mulching, staking, and an occasional pinching-in during the growing season will be accompanied with good effect in productiveness and size of fruit.

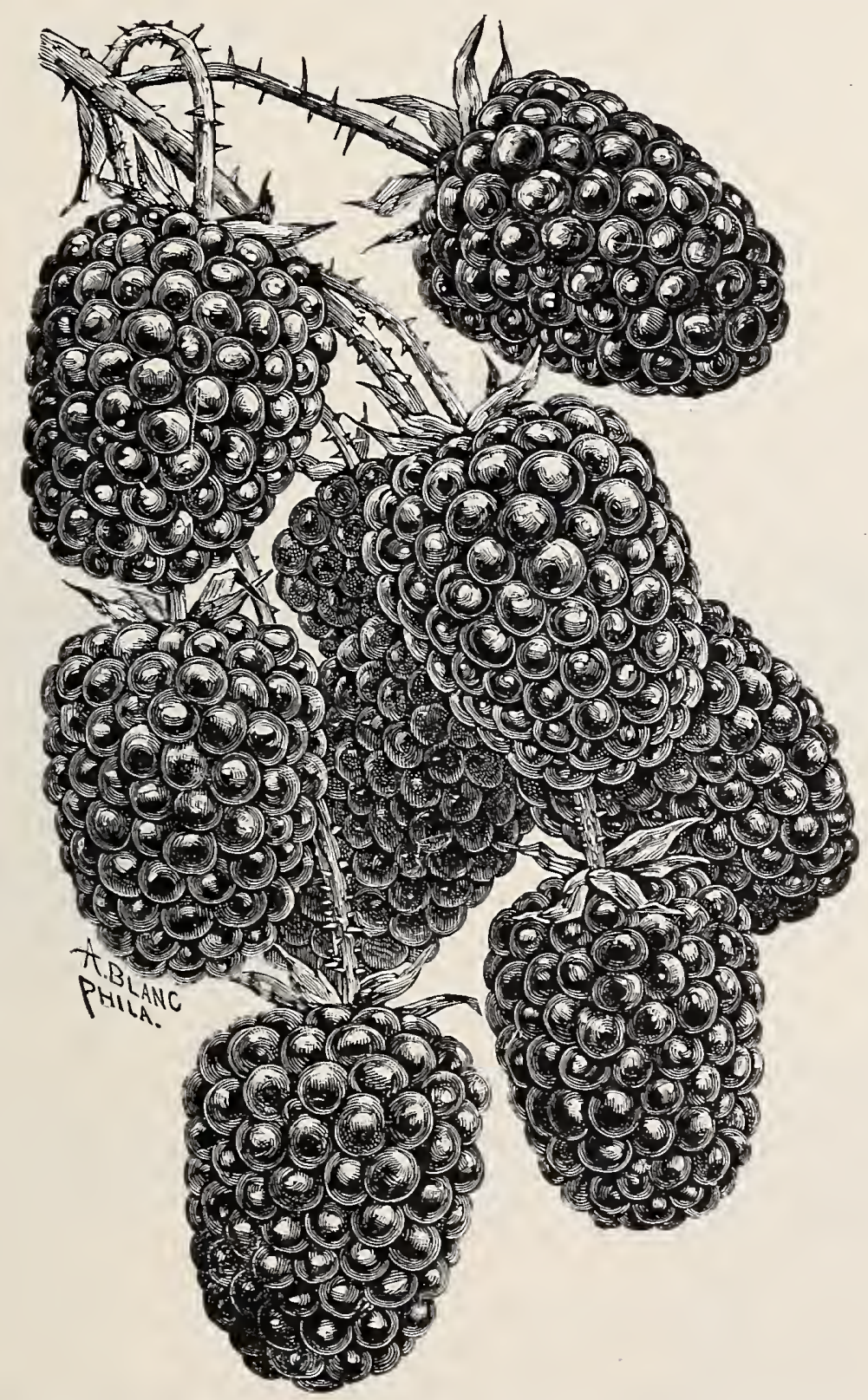

ERIE. $\checkmark_{A}$ chance seedling but recently brought to the notice of the public, and considered a valuable acquisition, being perfectly hardy and very productive, fruit of first quality, large size, and ripens early. See cut.

MINNEWASKA. $\boldsymbol{k}$ Has been on trial in different parts of the country and is receiving favorable reports from nearly all sections. Fruit is of largest size, glossy black, tender, juicy, sweet, with a fine aron!atic flavor. Remarkably productive and sardy. Promising for both market and garden. 
SNYDER.-Highly esteemed and very hardy, and enormously productive, of medium size, excellent quality and valuable for home and market.

WACHUSETT THORNLESS. - A hardy variety comparatively free from spines, fruit of large size and delicious. Succeeds best under good culture.

WILSON, JR.-A seedling of Wilson's Early, and claimed to be an improvement on 'he. parent by being earlier, larger, healthier, more productive and of better analitu We have in stock these additional varieties:-Kittatinny, Lawton, Taylor.

\section{Dewberries or Trailing Blackberries.}

LUCRETIA.--The bush is of low trailing habit, hardy, healthy and great bearer, fruit large, black and glossy. Without hard core and very delicious. Ripens with early blackberries.

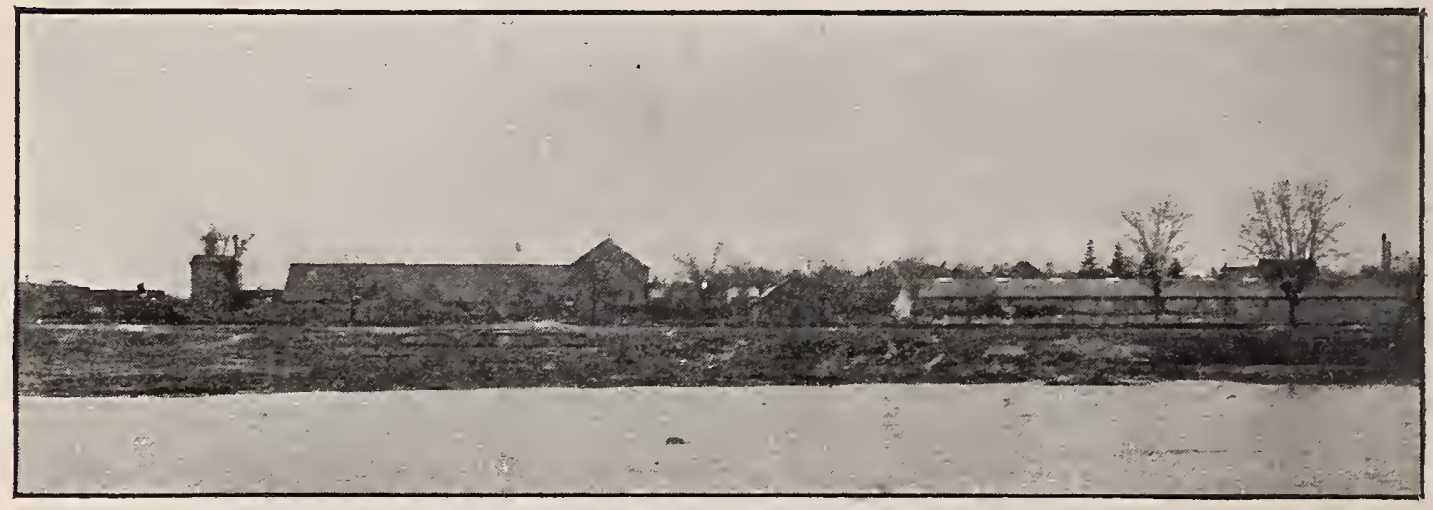

PACKING GROUNDS AND CELLARS.

I. E. Ilgenfritz' Sons,

Moscow, Mich., ApRIL 27, I8g6.

Received the trees and bushes ordered, in good shape, at North Adams, Thursday.

Respectfully,

S. C. PARTSER.

I. E. Ilgenfritz' Sons, Monroe, Mich.

Custer, Mich., MaY 4, I8g6.

Dear Sirs, - I send you this day (Nay 4th) by post office order, SII.50 in payment for trees received April 26th. The trees were in good order and pleased me very much.

Yours sincerely,

JOÉ JOLBERT.

I. E. ILGENFritz' SONS,

Barneveld, Wis., April 30, i8g6.

Dear Sirs, - The trees arrived in good order. Everybody is well pleased with them.

Yours truly,

E. D. EVANS.

I. E. IlgeNFritz' SONS,

ANT ARBOR, APRIL 27, I8g6.

Dear Sirs,-I received the peach and plum trees the same day they arrived in Ann Arbor. The trees were in fine shape. I send you by draft \$99.00, after deducting freight. Please let me know when received.

Yours truly,

E. POPKINS. 


\section{STRAWBERRIES.}

No GaRDEx should be destitute of this delicious fruit. They are easily grown and productire. One rod square. well treated, should vield at least two bushels. The ground should be deeply spaded and well manured. They can be planted at almost any season of the year. Of course, if planted in warm diy weather, they must be watered and sliaded. The runner's should be kept cut off, which can be easily done with a sharp spade. In the Winter leares, coarse manure or litter should be placed around and ()rer them.

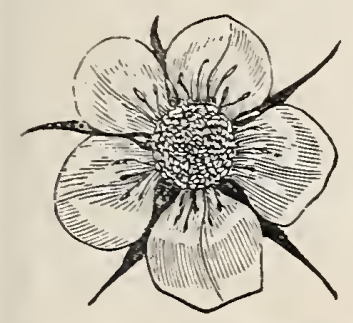

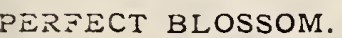

The cuts here given represent the bi-sexual or perfect, and pistillate or imperfect flowers. The blossoms of those marked with a (P) are termed pistillate and require perfect flowering sorts to be planted at intervals not to exceed a rod away, so as to properly fertilize them, or they will produce but little fruit and it will be imperfect at that: but when properly fertilized they are more productive than the perfect flowering varieties.

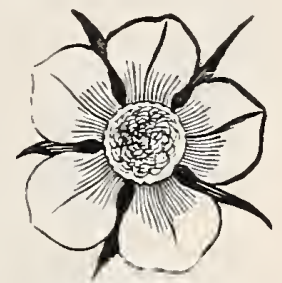

IMPERFECT BLOSSOM.

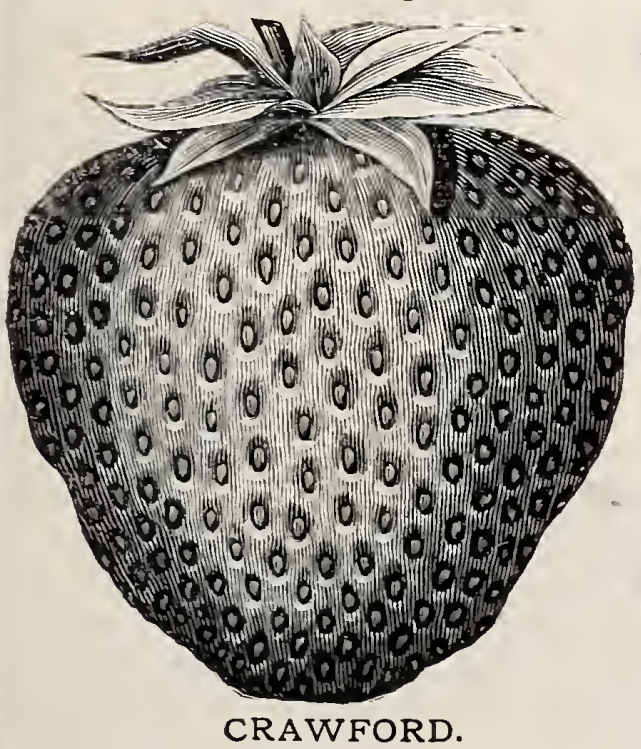

CRESCENT SEEDLING.-(P) One of the most productive varieties, bright color and very profitable for near market, berries of good flaror and medium size.

CRAWFORD. $\simeq$ A variety of much promise for both home use and market. The plant is large and stocky, usually free from rust, a luxuriant grower and an abundant bearer, blossoms perfect, fruit very large and usually of regular form, color beautiful red, ripening without white ends. See cut.

GREENVILLE. $\boldsymbol{k}(\mathrm{P})$ A new berry that is being ranked among the best. Berry medium to large, rich bright color, firm texture, good quality and attractive. Plant vigorous, healthy

and productive. See cut.

JESSIE.-A seedling of the Sharpless, berry of very large size, continuing large to the last picking, bright, handsome color, flesh firm, of a delicious pineapple flaror. Plant a luxuriant grower, healthy, productive.

PARKER EARLE. - A remarkable new berry which originated in Texas, and so far as tried eminently valuable everywhere. Plant a robust grower, healthy and immensely productive. Fruit uniformly large, conical, witl short neck, glossy crimson, ripens all over, moderately firm, good quality, flowers perfect. Season medium to late. See cut.

SHARPLESS. - An excellent berry of enormous size. bright scarlet, somewhat glossy, flesh firm, moderately juicy, sweet, rich and very good. Plant very hardy and vigorous grower.

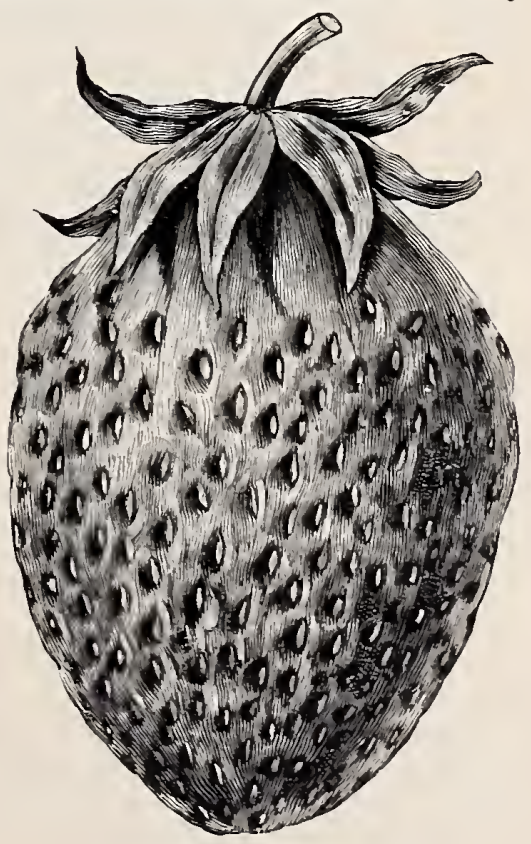

PARKER EARLE. 


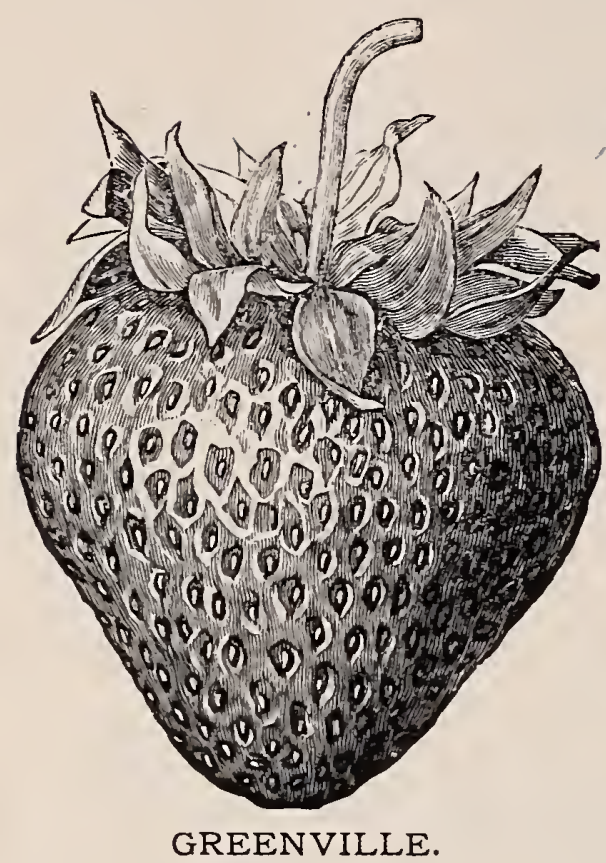

SHUCKLESS. This is the most remarkable straw. berry recently introduced, inasmuch as it possesses a novel and peculiar feature indicated by its name. In picking it readily parts from the stem, the shuck remaining on the stem instead of the berry. They are ready for the table as soon as picked, which will be appreciated by housekeepers and will place it in the front rank as a garden sort. It is also said to be a good shipper. The plant is a strong grower, hardy, late bloomer and productive. Berry of uniform size and color, quality of the best.

We have in stock these additional varieties:-

Bubach, Cumberland Triumph, Gandy, Haverland, Kentucky, Leader, Manchester, Michael's Farly, Perry, Wilson's Albany, Warfield.

I. E. Ilgenfritz' Sons, Monroe, 'Mich.

Toledo, Ohio, Nov. 8, isg6.

Dear Sirs, - Enclosed please find check. \$7.40, amount of bill for trees. The trees appeared to be a very fine lot and in prime condition. I am obliged to you for your care and promptness in filling the order.

Yours truly,

GEO. B. BOONE.

I. E. Ilgenfritz' Sons, Monroe, Mich.

YPSilanti, MAY + , i 896.

Gentlemen,-I have received the trees in good time and in good shape. I had them set immediately, and they look as if they would do well. I thank you very much for the extra tree. I will speak a good word for you to my friends.

Yours respectfully,

MIRS. S. J. VAIL.

I. E. Ilgenfritz' Sons,

Lakeside, OHio, April 24, is 86 .

Dear Sirs,--Enclosed find $\mathbf{\$ 2 . 4 4}$, which is sum due you for trees delivered at Marble Head Junction, April 2oth. The trees were all up to the grade ordered, and some of them better than I expected. Please send me one of your descriptive catalogues, and oblige

Yours respectfully,

A. KENNE.

1. E. ILGENFritz' SoNs,

Barker Creek, Mich., May 5, isg6.

Dear Sirs, - I saw your stock of trees delivered here this spring, and will say without any doubt they are the best trees delivered here by any one. Yours truly, 


\section{GOOSEBERRIES.}

THIs fruit is of importance, being very highly valued in its green state for pies, tarts, puddings, etc., coming in use earlier tlian any other. When ripe it is very agreeable as a dessert fruit, maturing at an acceptable time, following the season of cherries. The gooseberry requires a deep soil, well manured, and if inclined to be dry should be mulched to retain the moisture. The bushes should be thoroughly trimmed and pruned to obtain large, fine fruit.

DOWNING'S SEEDLING.-Origin, Newburg, N. Y. Fruit larger than Houghton, roundish. light green, with distinct veins, skin smooth, flesh rather soft, juicy and very good. Vigorous and productive.

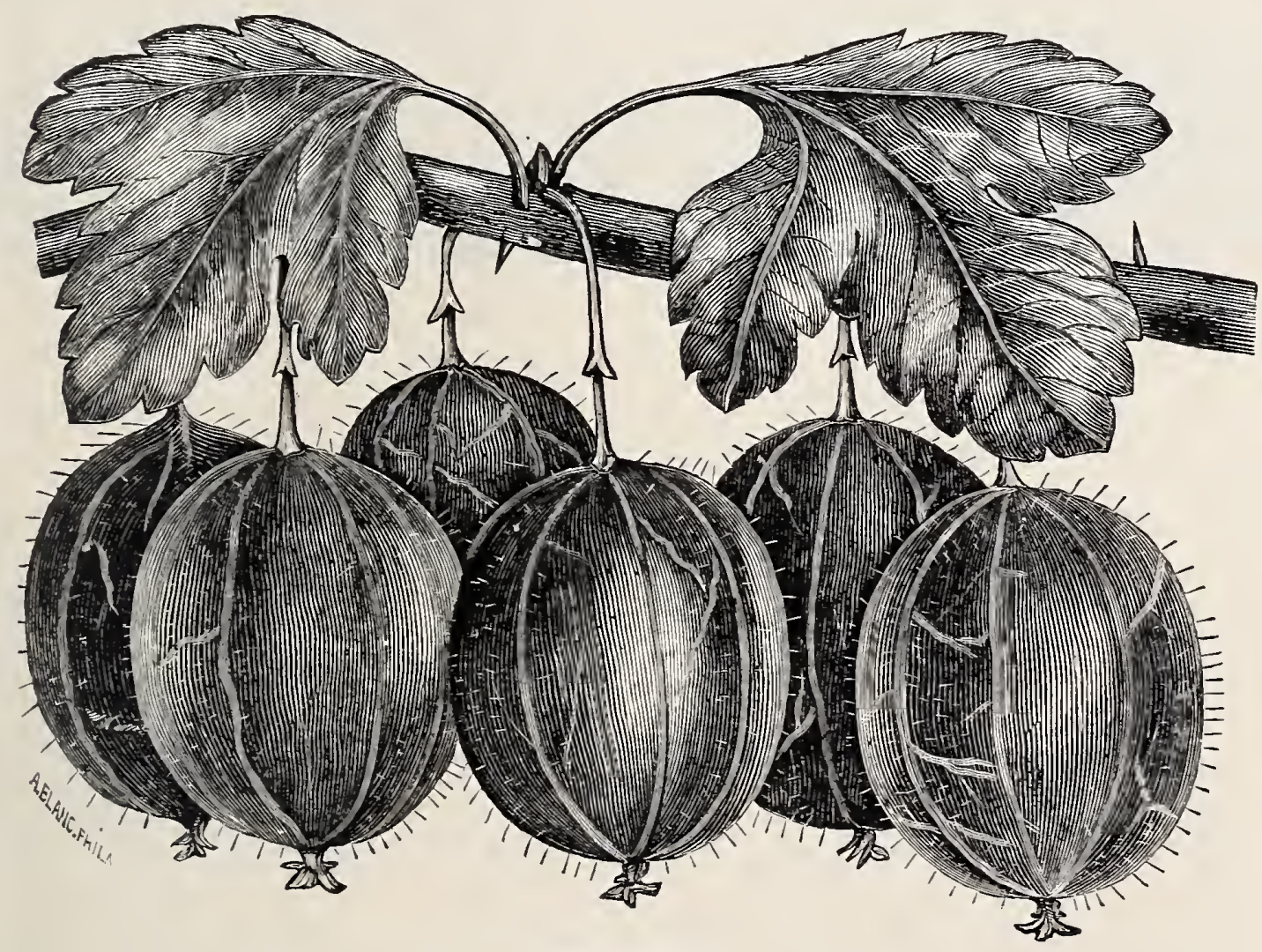

INDUSTRY.

HOUGHTON'S SEEDIING.-A vigorous American sort, very productive, free from mil. dew, fruit medium, roundish, smooth, of a pale red color, tender, sweet, and of a delicate flavor.

RED JACKET. $\swarrow_{\mathrm{A}}$ new red berry of the largest size, smooth, quality of the best, very prolific and hardy. Said to be absolutely free from mildew in leaf and fruit. Promises to be the variety we have been long waiting for; equal to the best English sorts, and capable of producing large crops under ordinary cultivation, wherever Goosebseries can be grown. 


\section{Foreign Varieties.}

There are very few of these that succeed here on account of their liability to mildew, and otherwise being more or less uncertain, but the following varieties are believed to be exempt from these drawbacks to a degree entitling them to a place in our American gardens :-

INDUSTRY.--A new promising English variety, very large, handsome, dark red, with a rich, pleasant flavor. free from mildew, robust grower and extremely prolific. No doubt will prove a valuable acquisition.

KEEPSAKE. A new variety from England, which promises to become as popular as the Industry. Fruit very large, straw color, of excellent flavor and a fine shipper. The bloom is protected by early foliage, making it a sure cropper. Une of the very earliest varieties under cultivation.

We have in stock these additional varieties of Gooseberries:-

Crown Bob, Golden Prolific, Smith's Improved, Triumph, White Smith.

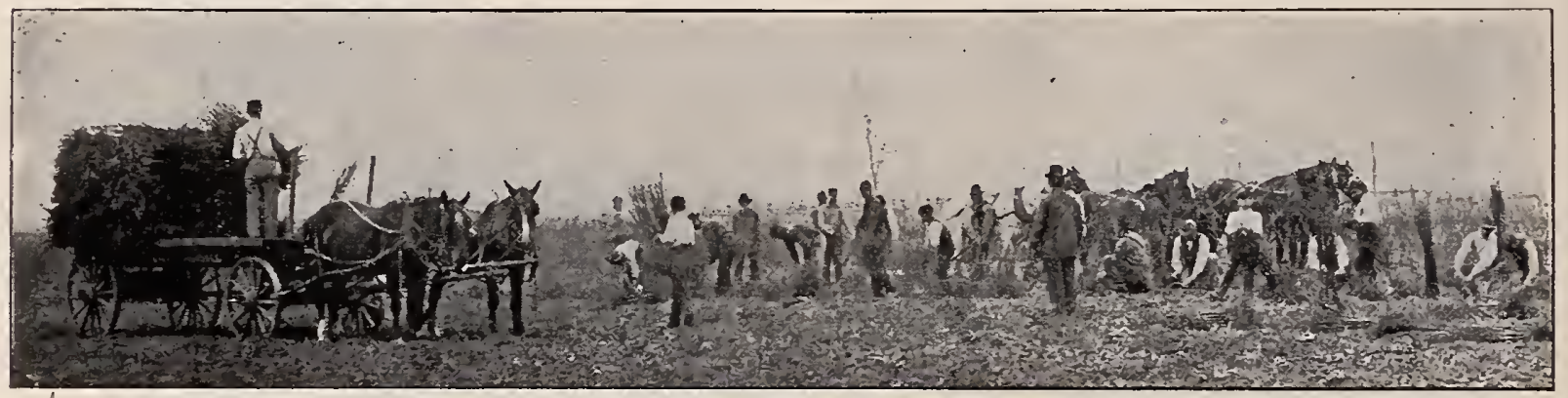

DIGGING PEACH TREES.

Messrs. I. E. Ilgenfritz' Sons,

Edgerton, OHio, MaY I4, i8g6.

Dear Sirs.--The two Irish Junipers you sent by express arrived in good shape. Am well pleased with your manner of doing business.

Resp. yours,

JOSEPH MILLER.

I. E. ILgENFritz' Sons,

Gentlemen,-Trees arrived here today in good condition.

Hutchinson, Minn., May 2, i8g6.

iours truly,

A. J. LALGESON.

Mr. ILGENFRITZ' SONS,

Perrysburg, Ohio, April 28, 1896.

Yours with trees came to hand all right, and were in good shape. Find enclosed draft for sir.70. Please let me hear from you, on receipt of this. Yours,

C. C. THUM.

I. E. ILGENFritz' SoNs,

Rochester, Mich., June 5, i 896.

Gents.,-Enclosed find draft for $\$ 6.00$. Trees were very satisfactory.

Yours truly,

A. G. GRIGGS.

I. E. Ilgenfritz' Sons, Monroe, Mich.

LEE. MICH., ОCT. 24, I895.

Dear Sirs, - The bill of trees received yesterday, and I have them heeled in. Received in good shape: quite a fine lot of trees, fully as good as I expected. Am very well pleased. I will send you today $\$ 70$ cash, by express or express money order, and hope that will make you pleased too. Yours truly.

A. BORDINF. 


\section{MULBERRIES.}

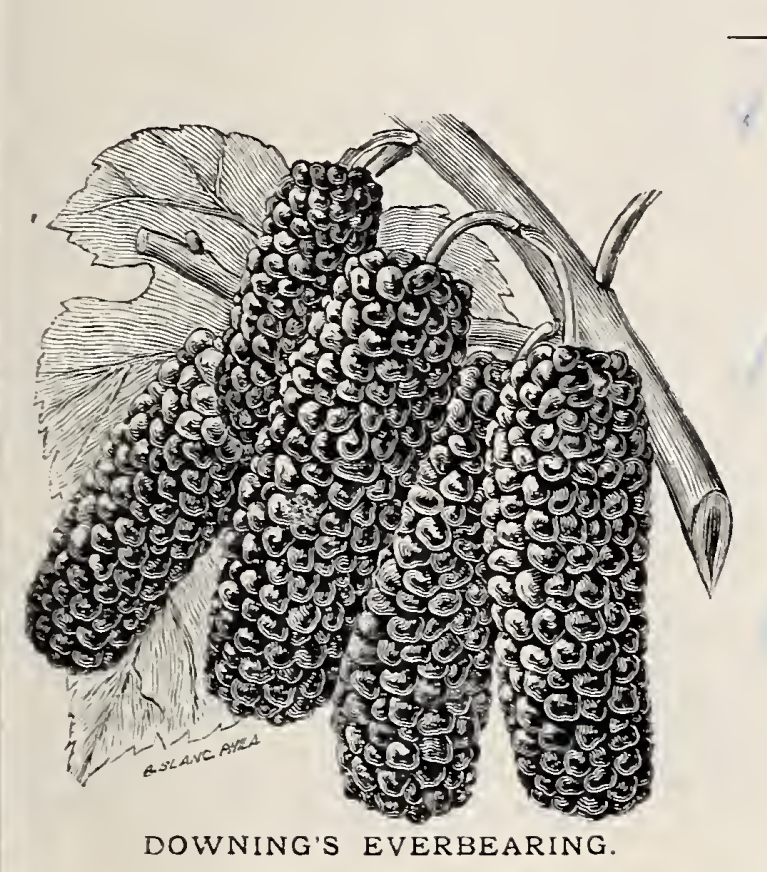

DOWNING'S EVERBEARING. - A fine rapid growing tree with large foliage and attractive for the lawn, and at the same time bears a delicious fruit for about three months. See cut.

NEW AMERICAN.--Fruit large, black, of fine quality and tree vigorous, a good bearer and highly ornamental for the lawn.

RUSSIAN.-Tree a rapid grower and consid. ered very hardy and valuable for timber. The fruit is of medium size and good. The foliage is abundant and said to be raluable for silk culture.

\section{ESCULENT ROOTS.}

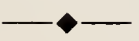

\section{Asparagus.}

CONOVER'S COLOSSAL. - The very best variety in cultivation.

PALMETT0.-OO Southern origin, has been planted in different parts of the country with good success. It is a good yielder, of even and regular growth, earlier than Conover's Colossal, and of best quality.

\section{Rhubarb.-Pie Plant.}

MYATT'S LINNAEUS.-Large, early and excellent. The most desirable. 


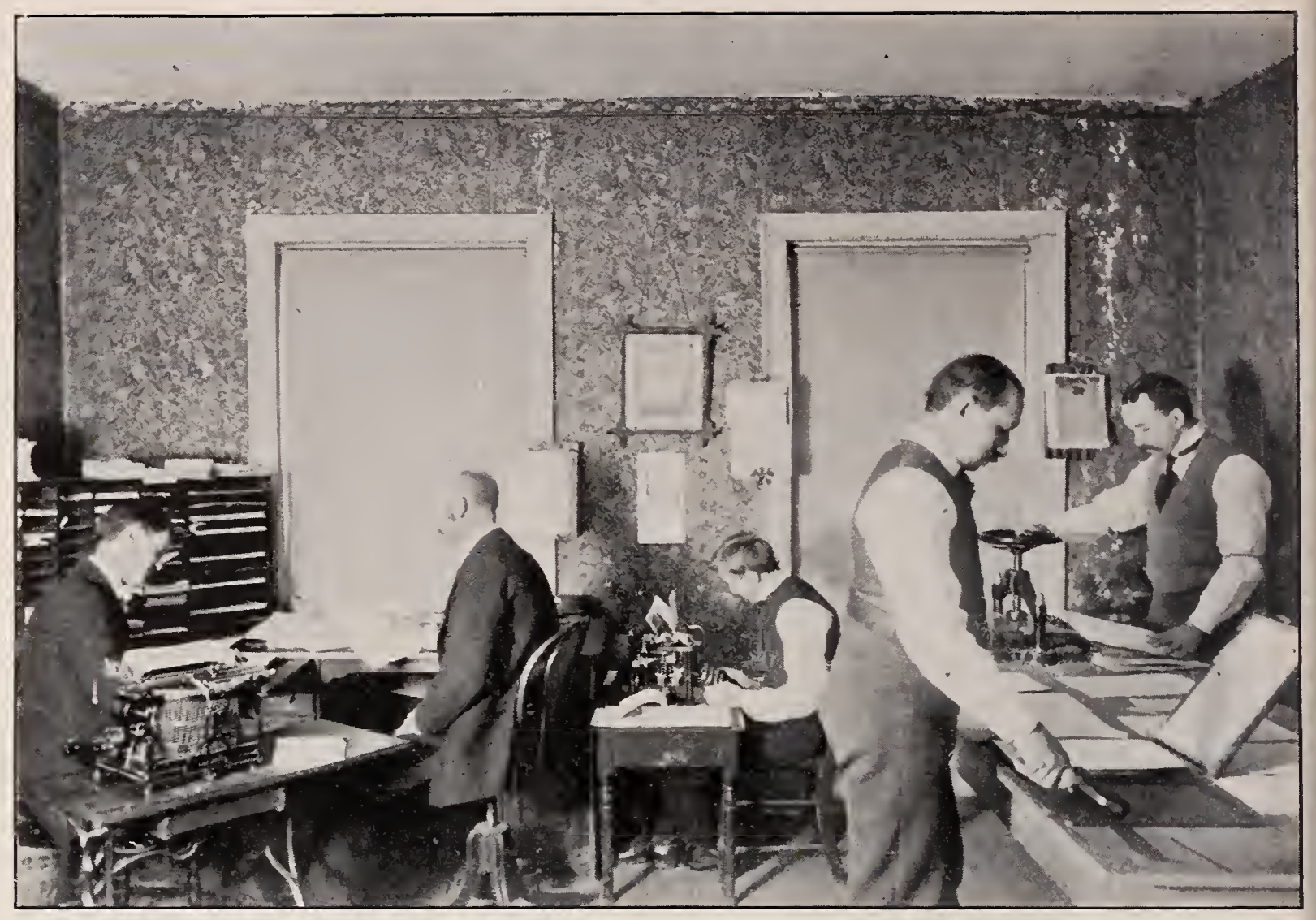

AGENCY DEPARTMENT.-Room 6.

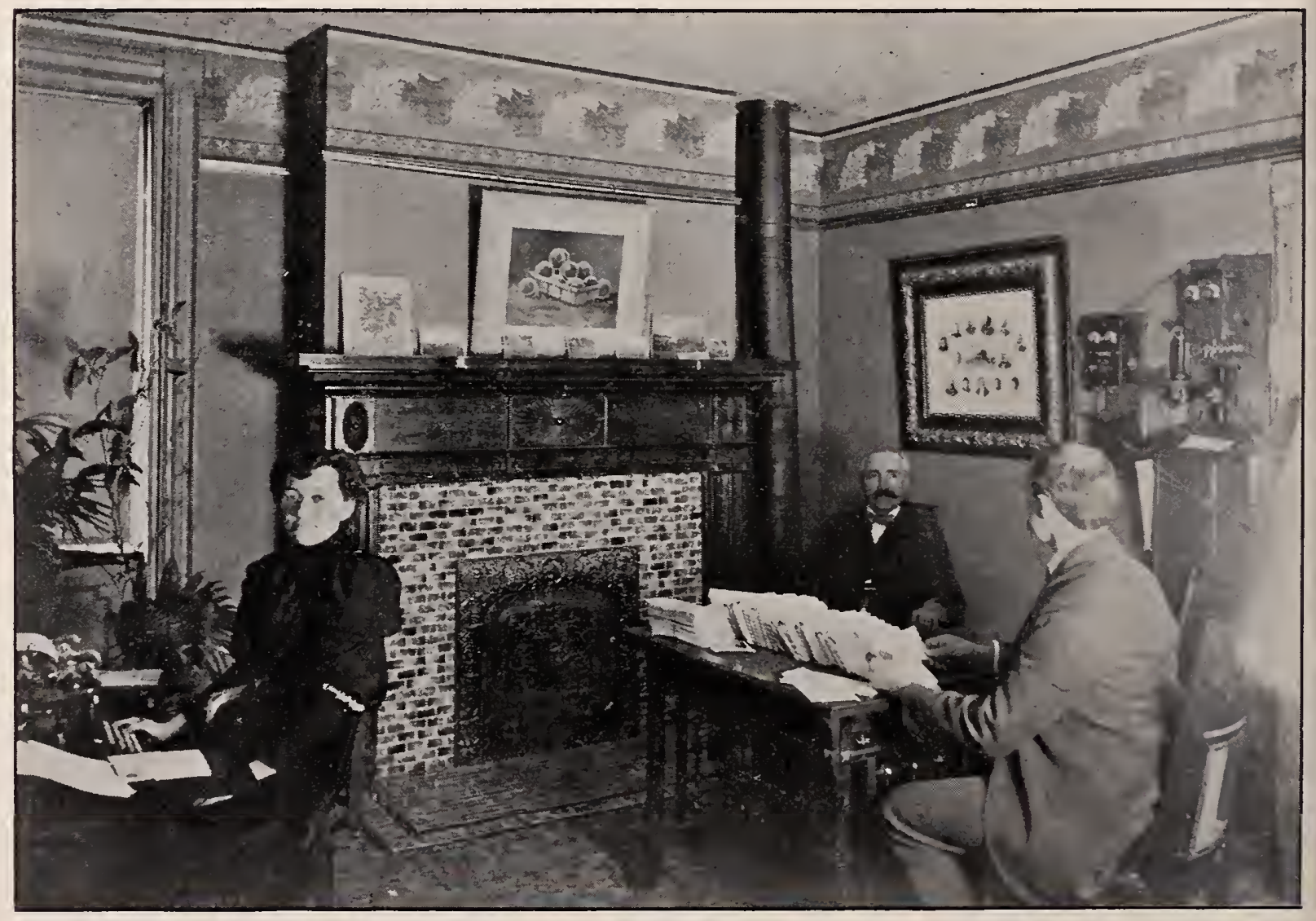

RECEPTION ROJM.-Room 2. 


\section{MISCELLANEOUS FRUITS AND NUTS.}

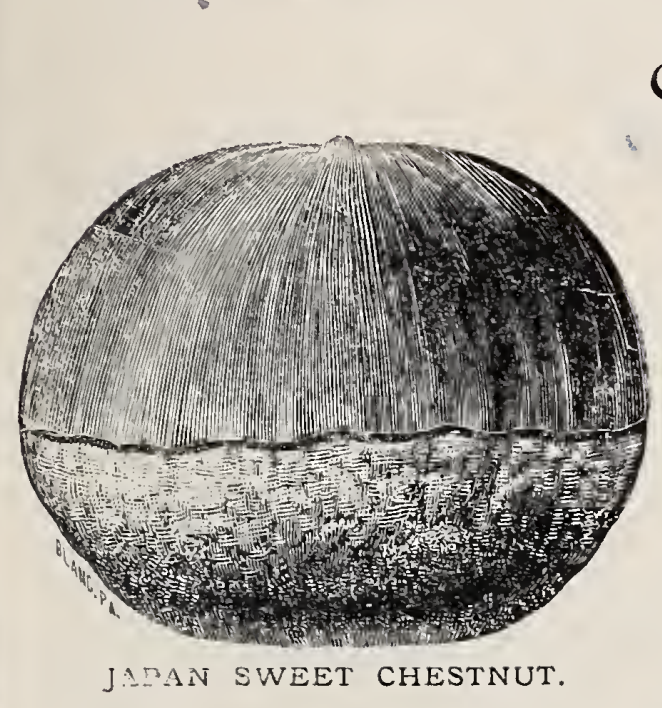

\section{Chestnuts.}

AMERICAN.-Well known in many parts of the country. It is unrivalled in beauty for the lawn, as well as valuable for the nuts that it bears in profusion.

JAPAN, OR MAMIMOTH.-.-One of the good things recently introduced from Japan. The tree is very hardy, productive and decidedly orna. mental. Nuts are of enormous size, and of the sweet, pleasant flavor of the American chestnut.

\section{Persimmon.}

NATIVE.-Fruit somewhat similar to the plum, yellow when ripe, sweet and good after exposure to frost.

\section{Walnut.}

BLACK.-.. Very valuable both for the fruit and the timber, tree attains large size and najestic form, suitable for large grounds and very desirable, nut round.

ENGLISH.-A native of Persia, tree very vigorous and handsome, producing an oral, rich, fine flavored nut.

I. E. Ilgenfritz' Sons, Nurserymen.

Monroe, Mich., June 22, isg6.

Dear Sirs, - I purchased I 200 fruit trees from you five years ago and am very much pleased with them. They are all true to name, and of excellent quality. I have bought some every year since, and can truthfully say I believe I have the best orchard in Michigan without any exception, and I would -acommend those wishing to buy the best fruit trees to deal with you. Refer to me when you please.

P. M. DENTEL, Monroetown.

I. E. Il Yours

Battle Creek, Mich., April 25, iEg6.

Gentlemen, - The bill of fruit trees came to hand and seem to be all right. They were in fine condition and I have them all set out and will remit you $\$ 22$ just as I agreed. Hoping that you will always have success, I remain Yours very truly,

C. L. HOGUE.

I. E. Ilgenfritz Soxs, Monroe, Mich.

Fenton, Mich., April, 27, iso6.

Dear Sirs, - I received my trees and they were in fine condition. Enclosed you will find express order for amount due. I hope you will remember and send me one of your catalogues, for next year, as I prefer to buy my trees from you. 


\section{ORNAMENTAL DEPARTMENT. DECIDUOUS TREES.}

\section{Beech-Fagus.}

PURPLE LEAVED, (Purpurea).--Very dark purple foliage, highly ornamental, and when placed on lawns with evergreens and other trees it has a most happy effect. See cut.

\section{Birch-Betula.}

CUT-LEAVED, (Laciniata).--Makes a very ornamental tree for lawn and street, on account of slender, drooping branches and shining, tremulous foliage. Very desirable. See cut.

COMMON WHITE, (Alba).--A well known variety, with silvery white bark, smooth leaves and pliant branches.

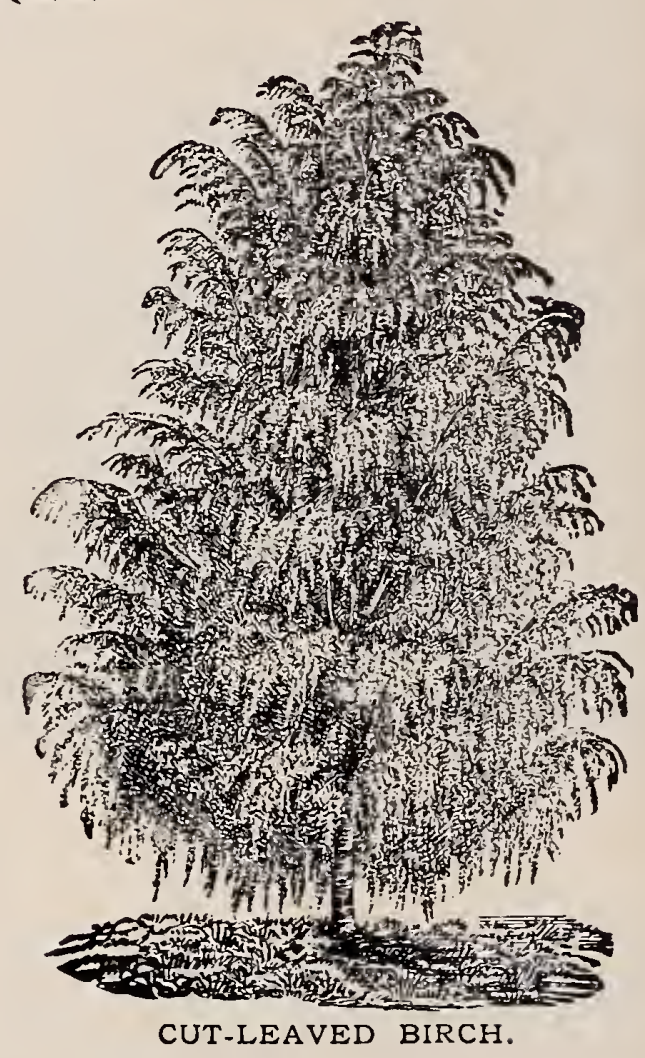

\section{Catalpa.}

BUNGEI, (Umbrella.)-On its own root a dwarf tree three to five feet high. Grafted on a stem it makes an umbrella-shaped top. The large, glossy leaves lay like shingles on a roof, making a symmetrical top. It is unique, attractive, and perfectly hardy.

SPECIOSA. - A hardy variety originated in the West, and is very valuable and popular.

\section{Elm-Ulmus.}

AMERICAN WHITE, (Americana).-A magnificent, stately tree, with wide spreading head and drooping branches.

ENGLISH, (Campestris).--An erect, lofty tree, of rapid compact growth, leaves smaller and more regularly cut than the American.

PURPLE LEAVED, (Purpurea).-A very beautiful variety, leaves of a rich purple when young.

WEEPING, (Camperdown Pendula).--Very drooping in habit, with large, dark green leaves. The finest weeping elm. See cut.

\section{Horse Chestnut-AEscullus.}

COMMON OR WHITE FLOWERED, (Hippocastanum).-A very beautiful, well-known tree, with round, dense head, dark green foliage, and an abundance of showy flowers in early spring. 


\section{Judas Tree, or Red Bud-Cercis.}

AMERICAN, (Canadensis).--Beautiful pea-shaped flowers, of a purplish pink color, produced in clusters close to the branches before the leaves expand. Neat heart-shaped foliage.

\section{Linden or Lime Tree-Tilia.}

AMERICAN BASSW00D.-A beautiful tree, having luxuriant foliage and fragrant flowers. An exceedingly rapid grower.

EUROPEAN, (Europœa).-A noble growing tree, of regular pyramidal form.

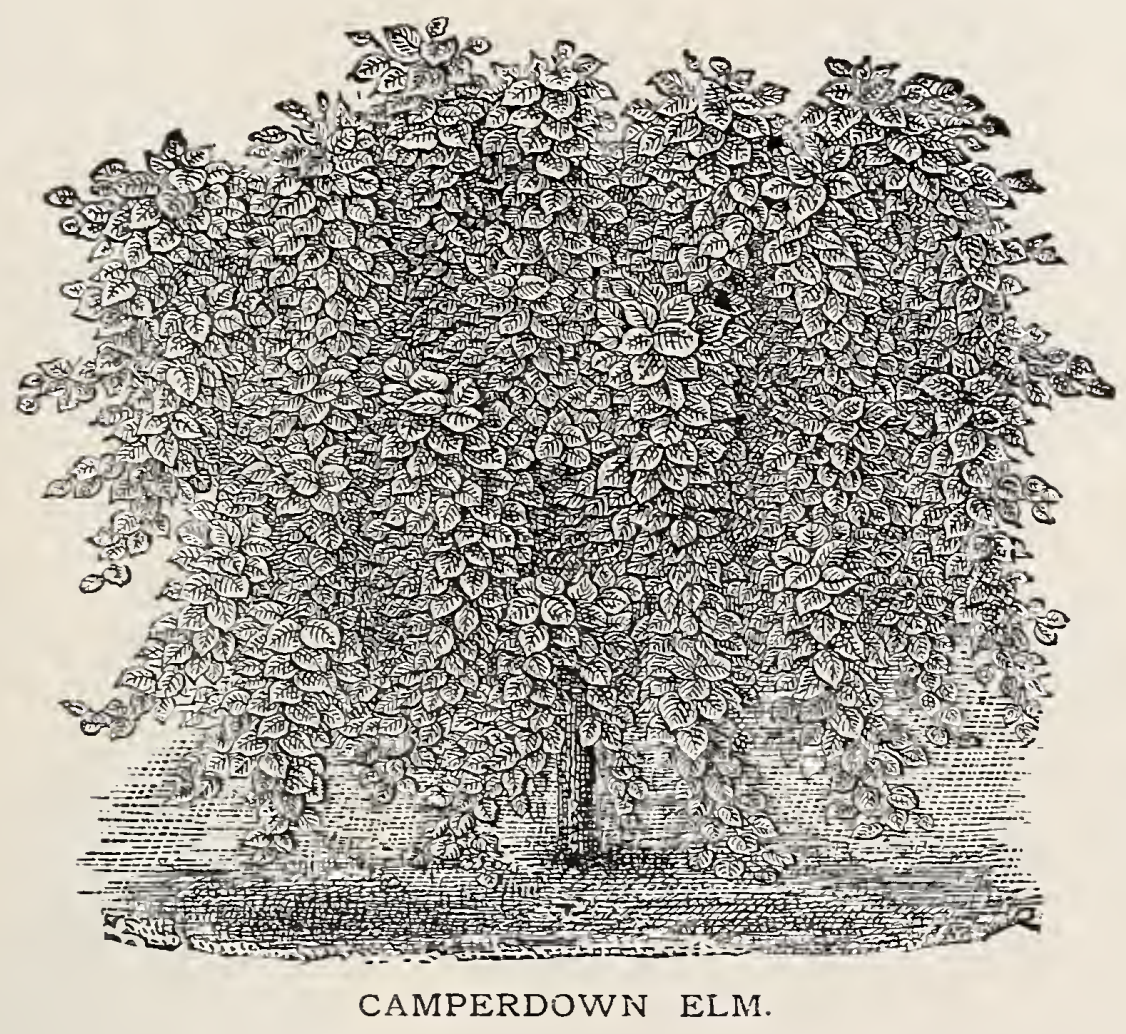

\section{Mulberry.}

TEAS' WEEPING. - A most graceful and hardy weeping tree. Forms a parfect umbrella shaped head with long, slender branches drooping to the ground. It has beautiful foliage and is wonderfully vigorous and healthy. One of the best and most reliable of weeping trees.

\section{Magnolia.}

POINTED LEAVED or CUCUMBER TREE, (Acuminata).-A noble variety, with rich, luxuriant foliage, and large, showy, bluish yellow flowers.

SOULANGEANA.-Closely resembles Conspicua, showy white and purple flowers. One of the hardiest and finest of the foreign variety. 


\section{Maple-Acer.}

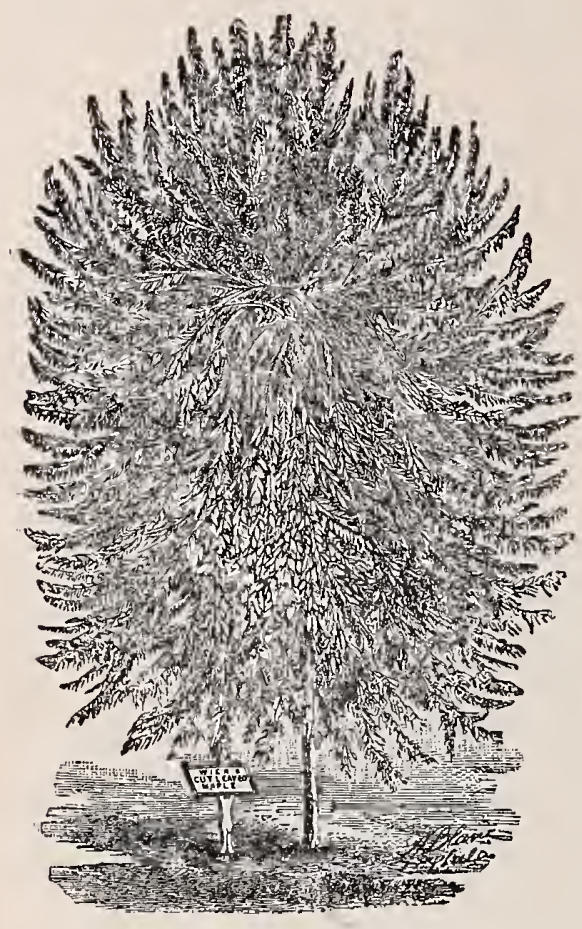

WIER'S CUT LEAVED MAPLE.
ASH LEAVED, (Negunda) Box ELDER. - A rapid grower, with leaves and young branches of bright green.

NORWAY, (Plantanoides).--One of the most valuable ornamental trees for lawn; broad, rich, dark green foliage, and of a compact globular form.

PURPLE LEAVED, (Pupurea).- One of the most beautiful and distinctly marked of all ; leaves purplish red, particularly on the under side. A rapid, strong grower, hardy, and should be in every collection.

SILVER LEAVED, (Dasycarpum).- Of exceedingly rapid growth and desirable for immediate effect.

SUGAR or ROCK, (Sacharinum).-A very popular American tree; and for its stately form and fine foliage justly ranked among the very best, both for the lawn and the avenue.

WIER'S CUT LEAVED, (Laciniata.)-One of the most desirable trees of cut or dissected leaves; of rapid growth, slender, drooping and graceful. Should be in every collection.

\section{Mountain Ash-Sorbus.}

EUROPEAN, (Aucuparia).--A fine hardy tree; head dense and regular, covered from July till winter with large clusters of bright scarlet berries.

AMERICAN, (Americana.)-A tree of coarser growth and foliage and brighter colored berries.

OAK LEAVED, (Quercifolia.)-A variety with large, downy, lobed leaves, distinct and fine.

WEEPING, (Pendula).-A very ornamental variety, with irregular drooping branches; desirable as a lawn tree.

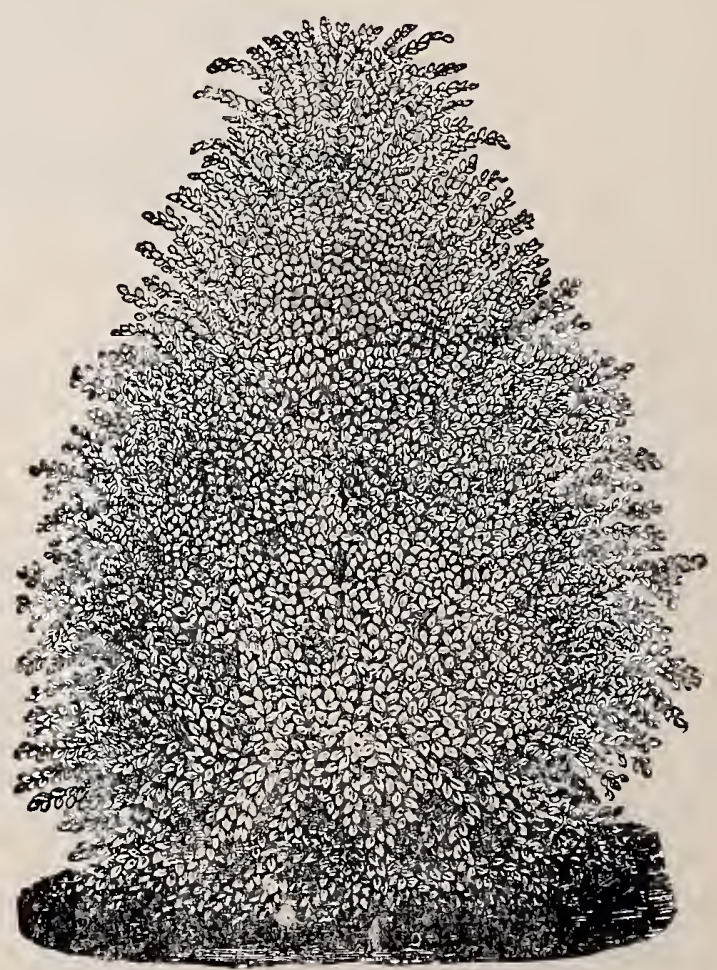

PURPLE LEAVED BEECH. 


\section{Poplar-Populus.}

on

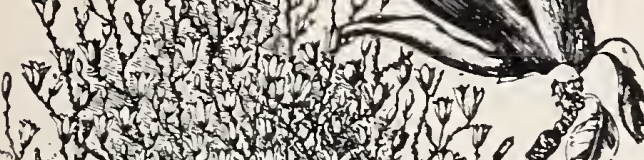
2. 3 (3) 7 J 1000 130 .
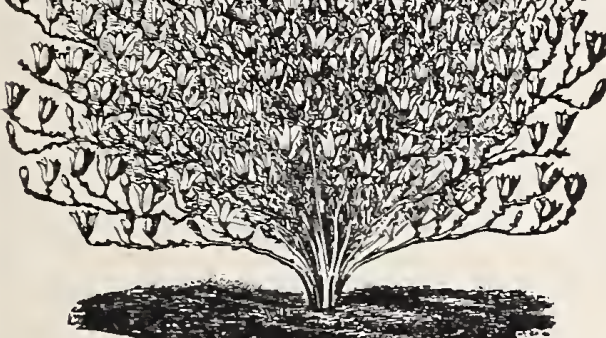

MAGNOLIA SOULANGEANA.

CAROLINA.--One of the most rapid growing trees; with large, deep green leaves that are glossy and handsome. Excellent for street planting: especially desirable in large cities, where it resists smoke and gas.

LOMBARDY, (Fastigiata).-A very distinct, well known variety of rapid growth and tall spiry form.

BOLIEANA.-- A very compact. upright grower; resembles the Lombardy. Has glossy leares, green above and silvery beneath. The bark of this variety is of a rich green color, giving it a very striking appearance.

AUREA.--Fine golden yellow foliage, retaining its brilliancy throughout the season.

\section{Salisburia.}

MAIDEN HAIR TREE, OR GINKGO, (Adiantifolia).-A singular and beautiful tree of medium size, foliage y ellowish green. curiously lobed and marked with delicate hair-like lines. Rare and desirable.

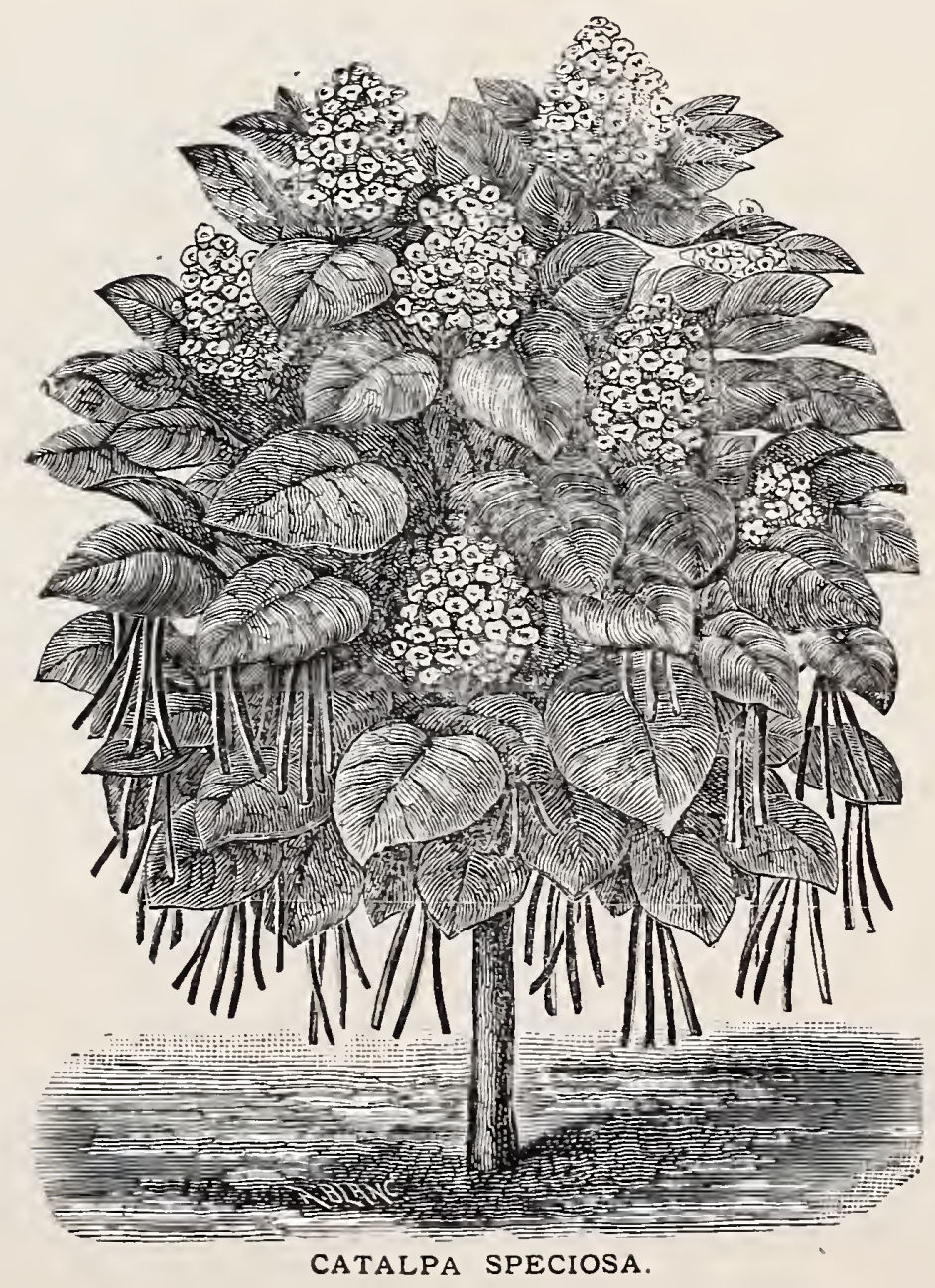




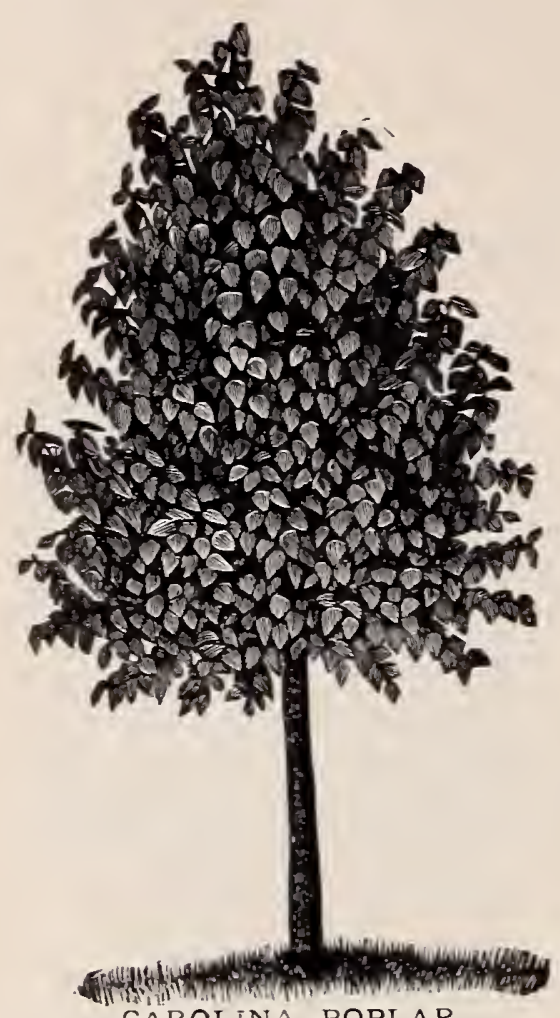

\section{Willow-Salix.}

COMMON WEEPING, (Babylonica).-A beautiful, graceful, well known tree. Very fine for planting by streams and ponds.

KILMARNOCK, (Capera Penđula).--A fine variety, with brownish, pendulous branches and heavy, dark green foliage.

NEW AMERICAN WEEPING, (American Pendula.)-A slender-growing artificial tree, with delicate drooping branches, forming a round full head; a beautiful ornament for the lawn.

ROSEMARY LEAVED, (Rosemarifolia)._-A very distinct variety of upright growth, foliage delicate and feathery, of a silvery white appearance, a small sized tree and especially desirable.

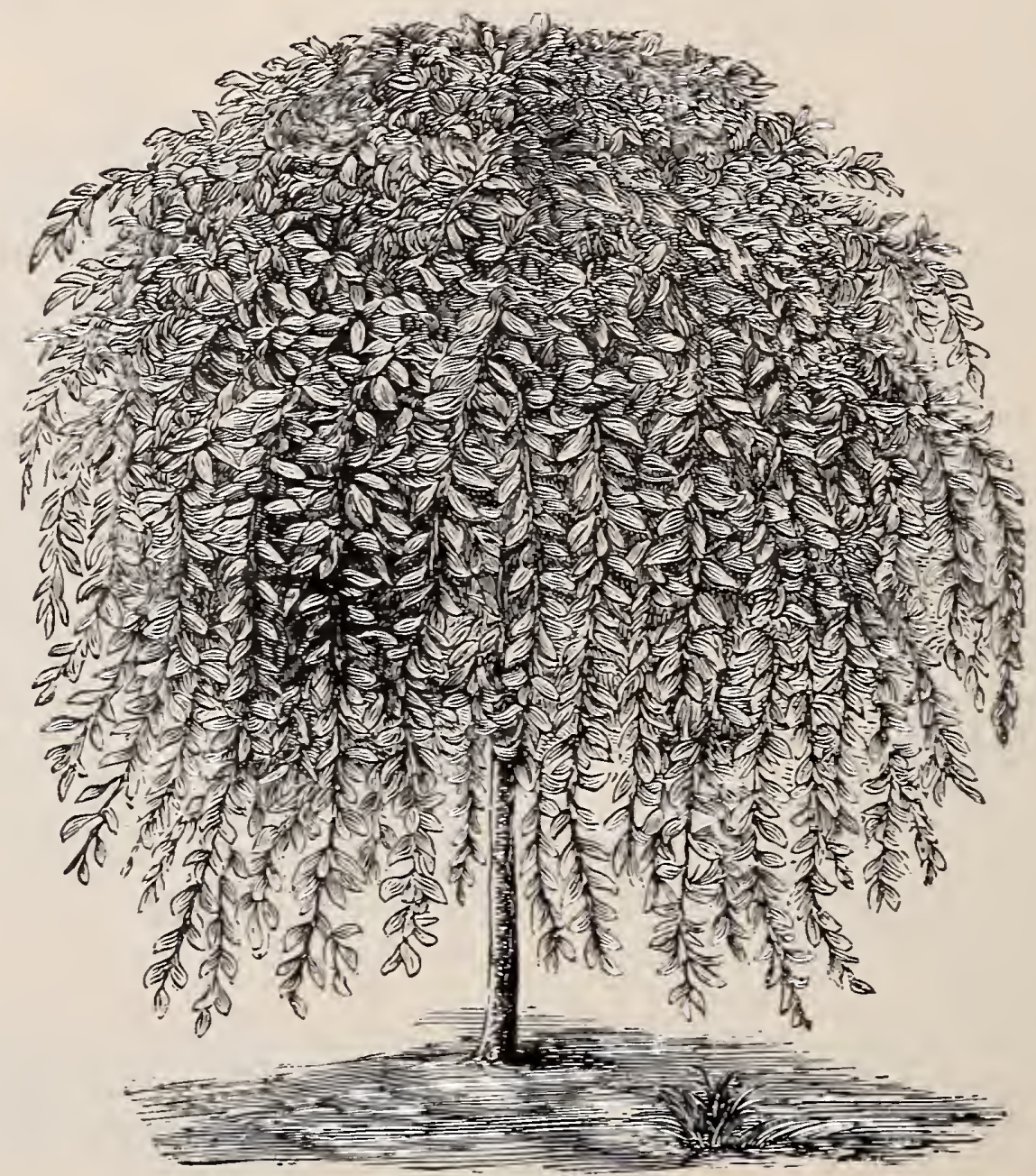

KILMARNOCK WILLOW. 


\section{DECIDUOUS SHRUBS.}

\section{Aithea Frutex, or Rose of Sharon-Hibiscus Syriacus.}

Free handsome shrubs, with large, bell-shaped flowers, blooming profusely through the autumn months.
Double VARIEGated,
DOUBLE RED,
Double Blue,
Double White,
Double Purple, Double Pink.

\section{Bechtel's Double Flowering Crab.}

This crab is the finest acquisition in the way of a flowering shrub that has been introduced in recent years. It is a rose in disguise, and sweet as a breath of Spring. The tree is sturdy, hardy, and free from disease. It grows to be a medium-sized tree and when in bloom presents the appearance of being covered with very delicate pink roses of medium size, scenting the atmosphere for a long distance with a perfume surpassing the fragrance of Tea Roses. Small trees have more the appearance of Tree Roses than anything else aud cut blosscims have often been taken for pink roses. This tree does not blossom until in full leaf which adds greatly to its beauty.

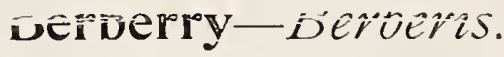

PURPLE LEAVED, (Purpurea).-Remarkable for its purple foliage and fruit. Valrable for borders.

\section{Calycanthus.}

SWEET-SCENTED SHRUB, (Floridus).-An interesting shrub, having a rare and peculiar fragrance of wood and flowers, blooms abundant, of a peculiar chocolate color.

\section{Cornus, or Dogwood.}

CORNELIAN CHERRY, (Mascula).--Bright yellow flowers early in May.

RED BRANCHED, (Sanguinea).-Very conspicuous and ornamental in winter, on accouit of its blood red bark.

\section{Currant-Ribes.}

The flowering currants are very ornamental shrubs, very beautiful in early spring, and easily cultivated.

YELLOW FLOWERING, (Aurea).

DOUBLE CRIMSON, (Sanguineum flore pleno).

\section{Deutzia-Dentzia.}

CRENATE-LEAVED, DOUBLE FLOWERING, (Crenata.) - A fine, strong growing shruli and profuse bloomer, flowers double, white tinged with rose.

GRACEFUL, (Gracilis).-A fine small shrub, suitable for pot culture, blooms free!y in a low temperature.

PRIDE OF ROCHESTER.-A charming variety, producing large, double white flowers, the back of the petals tinted with rose. It excels the older sorts in size of flowers, length of panicle, profuseness of bloom and vigorous habit. 
ROUGH-LEAVED, (Scabra).- A very strong growing shrub, producing beautiful white flowers in profusion.

VARIEGATED GRACEFUL, (Gracilis Variegata).-.Similar to Gracilis, with variegated foliage.

$$
\text { Euonymus-Strawberry, or Spindle. }
$$

AMERICAN, (Americanus).-A beautiful large shrub, or small tree. Its glowing crimson fruit makes it very attractive.

\section{Forsythia-Forsythia.}

VIRIDISSIMA, (Viridissima).-A fine hardy shrub, leaves deep green, blooms very early, with handsome yellow flowers.

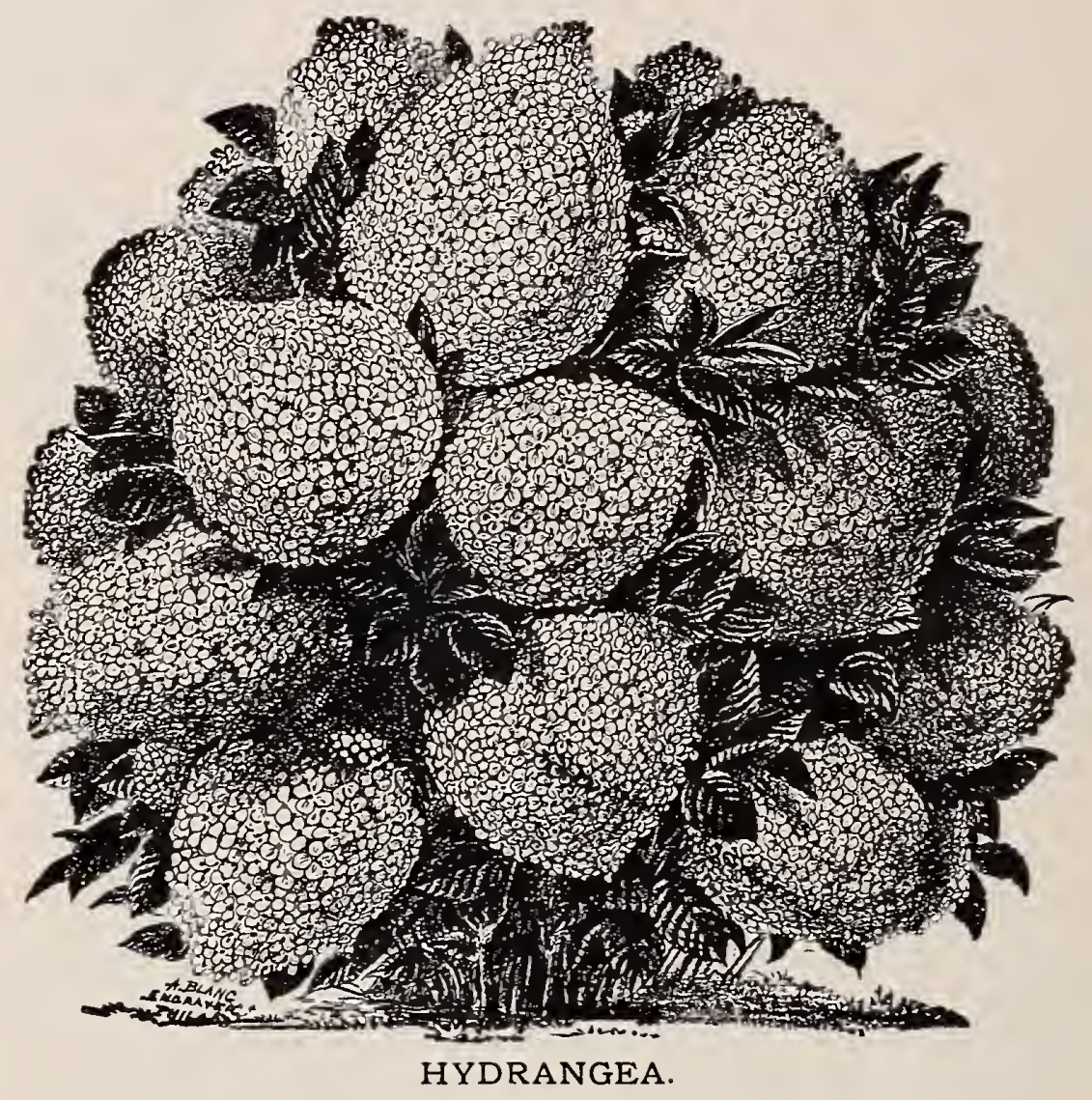

\section{Honey Suckle, Upright-Lonicera.}

RED TARTARIAN, (Tartarica Rubra).-A well known shrub, flowers pink, which appear in May.

WHITE TARTARIAN, (Tartarica Alba).-Like the preceding, but has dull, white flowers.

\section{Hydrangea.}

LARGE CLUSTERED,.(Paniculata Grandiflora).- A fine shrub of recent introduction, flowers pure white, large, showy and very profuse, quite hardy, and altogether one of the most desirable shrubs. Blooms through August and September. See cut.

RAMIS PICTIS, (Red Branched).--One of the latest acquisitions. Flowers produced in immense sized trusses, of deep rose color. The new growth of wood is of a deep reddish purple color, naking it distinct from any other variety. 


\section{Lilac-Syringa.}

COMMON, (Vulgaris).-A very strong growing shrub with purple flowers.

COMMON WHITE, (Vulgaris Alba.)--Similar to the preceding, with white flowers.

PERSIAN WHITE, (Persica Alba.)--Slender growing, but beautiful.

PERSIAN PURPLE, (Persica Purpurea).-Small leaves and bright purple flowers.

The above class of shrubs are very interesting and desirable for their beauty of foliage and profusion of fragrant and showy flowers, being some of the hardiest shrubs.

\section{Privet-Ligustrum.}

COMMON, (Vulgaris).-A fine growing, branchy shrub, with deep green foliage and white flowers, followed in the Autumn by dark purple berries. Valuable for ornamental hedges.

\section{Purple Fringe-Rhus Cotimus.}

A curious and ornamental shrub of spreading growth; brownish, fringe-like flowers giving it a very light and airy appearance.

\section{Quince-Cydonia.}

JAPAN, (Pyrus Japonica).- A very hardy shrub with double crimson flowers in great pro. fusion, early in the spring. Highly ornamental.

\section{Spirea.}

Hardly any class of plants is more universally admired than the Spireas; of regular shaped growth, requiring comparatively no attention, and producing their delicate white or rose-colored flowers in the greatest abundance, they form one of the most pleasing groups of all our flowering shrubs.

COLOSSO, or FORTUNEI.-Flowers deep, clear rose-color; foliage tinted with a peculiar brown or bronze.

DOUGLASS, (Douglassi).--Small spikes of rose-colored flowers. Handsome.

LANCE-LEAVED DOUBLE, (Reevesii Fl. Pl., or Lancelatta).- Flowers white and double, blooms freely in clusters. One of the best.

VAN HOUTTEI.- The most showy of all Spireas, and one of the best flowering shrubs in cultivation. Flowers pure white, in great clusters and whirls, forming cylindrical plumes two to three feet long; strikingly attractive when in bloom, and plant also pleasing at other times.

\section{Syringa-Philadelphus.}

MOCK ORANGE, (Coronarius).--A well known shrub with pure white flowers. Very fragrant.

GOLDEN LEAVED, (Aurea).--A very pretty shrub of medium size, with golden yellow foliage. It retains its color through the entire season, and creates a pleasing and striking effect, planted in groups with other shrubs. 


\section{Viburnum。}

PLICATUM.-An exceedingly beautiful species from Japan. Of moderate growth anl handsome placated leaves. Surpasses the common Snowball in several respects. Flowers pure white, in large globular heads.

SNOW BALL, (Opulus).-A strong growing and much admired shrub, with globular clus. ters of flowers.

\section{Weigela.}

AMABILIS.-One of the finest plants in the spring, very hardy and a rapid grower. Flowers very beautiful, worthy of a place in every collection.

HORTENSIS NIVEA.-A profuse bloomer of pure white flowers, very fine, difficult to propagate.

ROSE COLORED, (Rosea).-A new, beautiful and hardy shrub, with double rose-colored flowers in rich profusion; lately introduced from China by $\mathrm{Mr}$. Fortune. Blooms in May.

VARIEGATED LEAVED, (Nana Variegata).-A conspicuous variety with foliage finely marked with white and green. Very ornamental.

\section{White Fringe-Chionanthus.}

VIRGINIAN, (Virginica).--A rery beautiful shrub bearing curious snow white, fringe-like flowers: blooms abundantly and forms a most graceful and pleasing ornament.

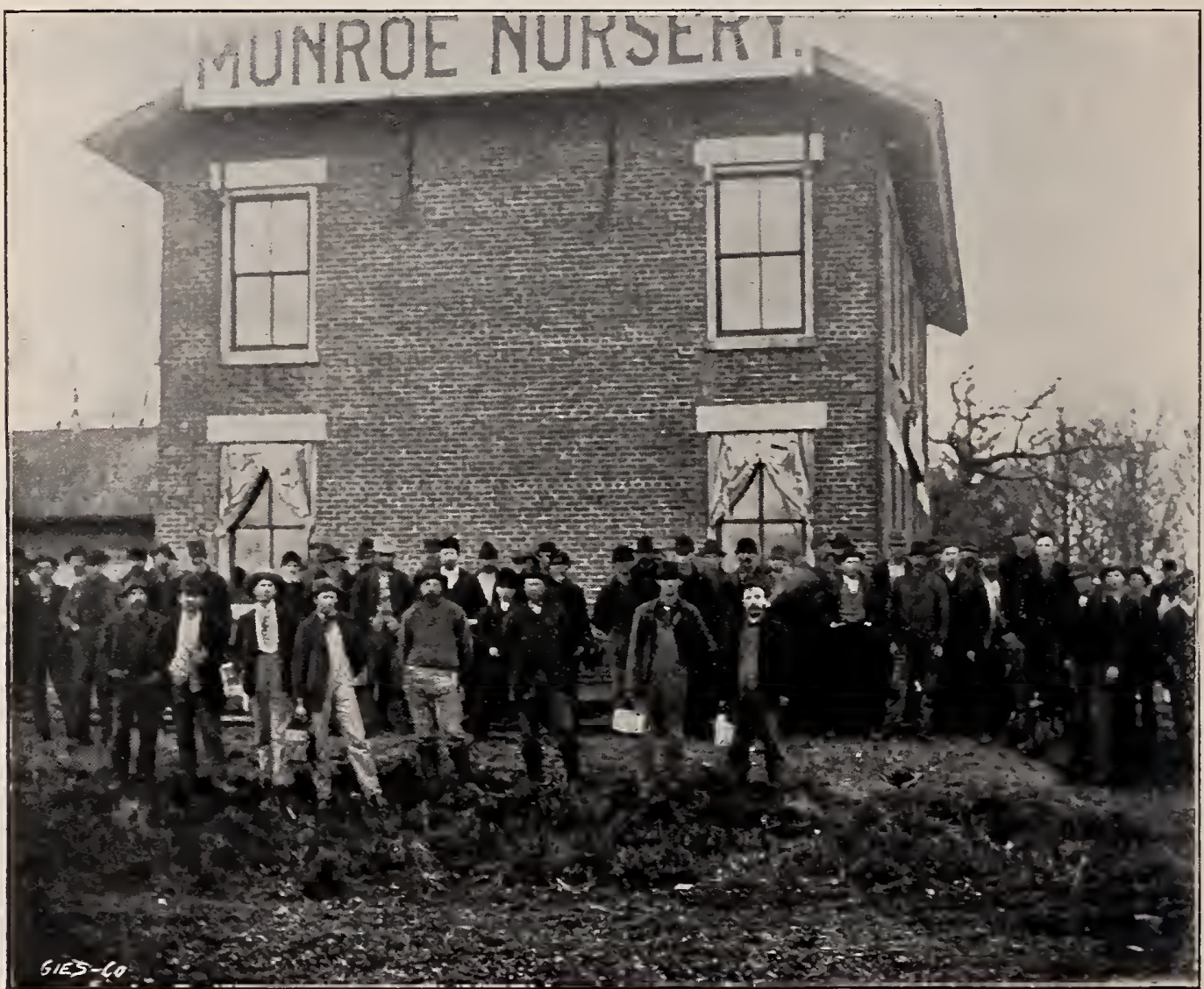

PAYING OFF FIELD-HANDS.-"Saturaay Night." 


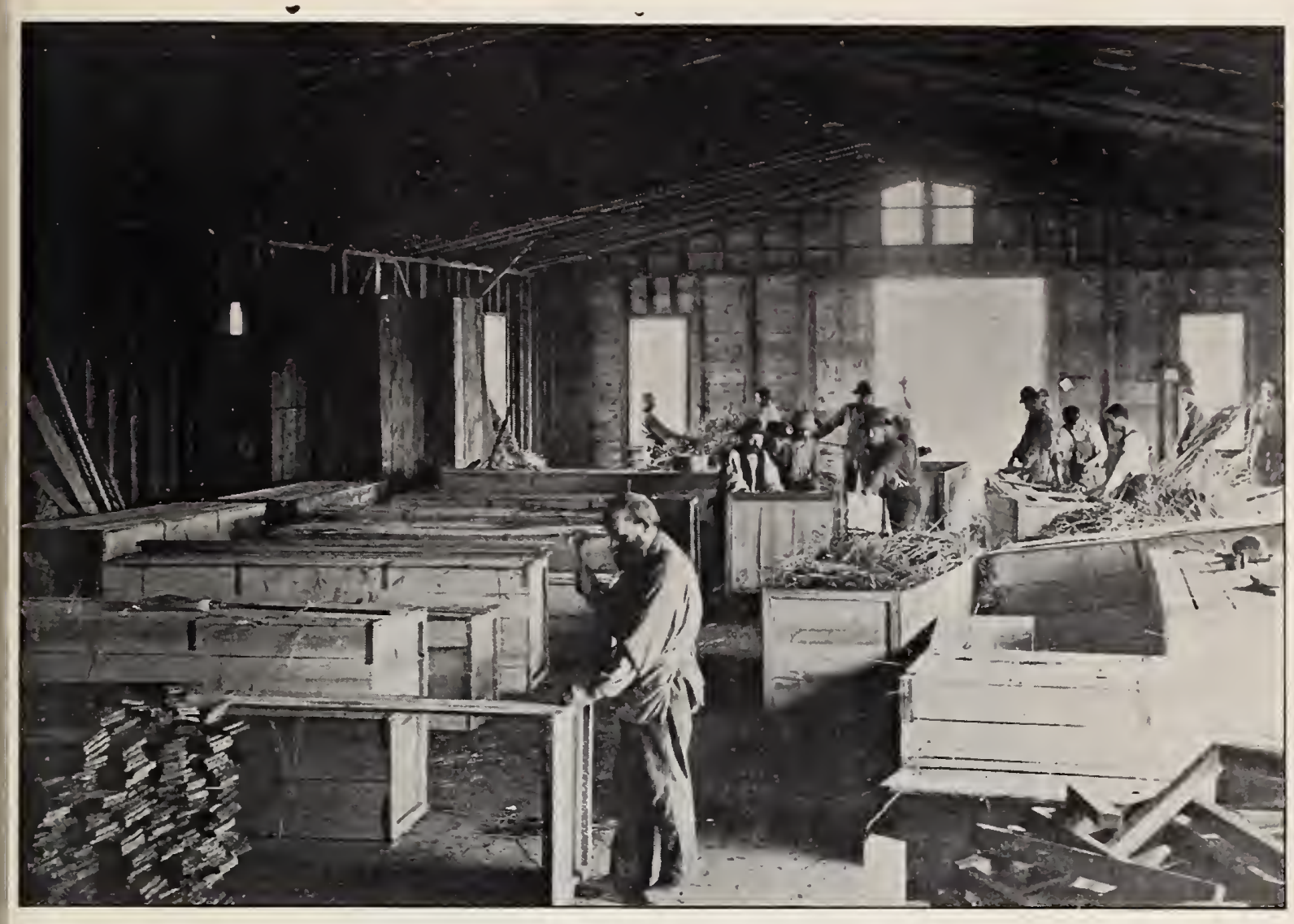

BOXING DEPARTMENT.

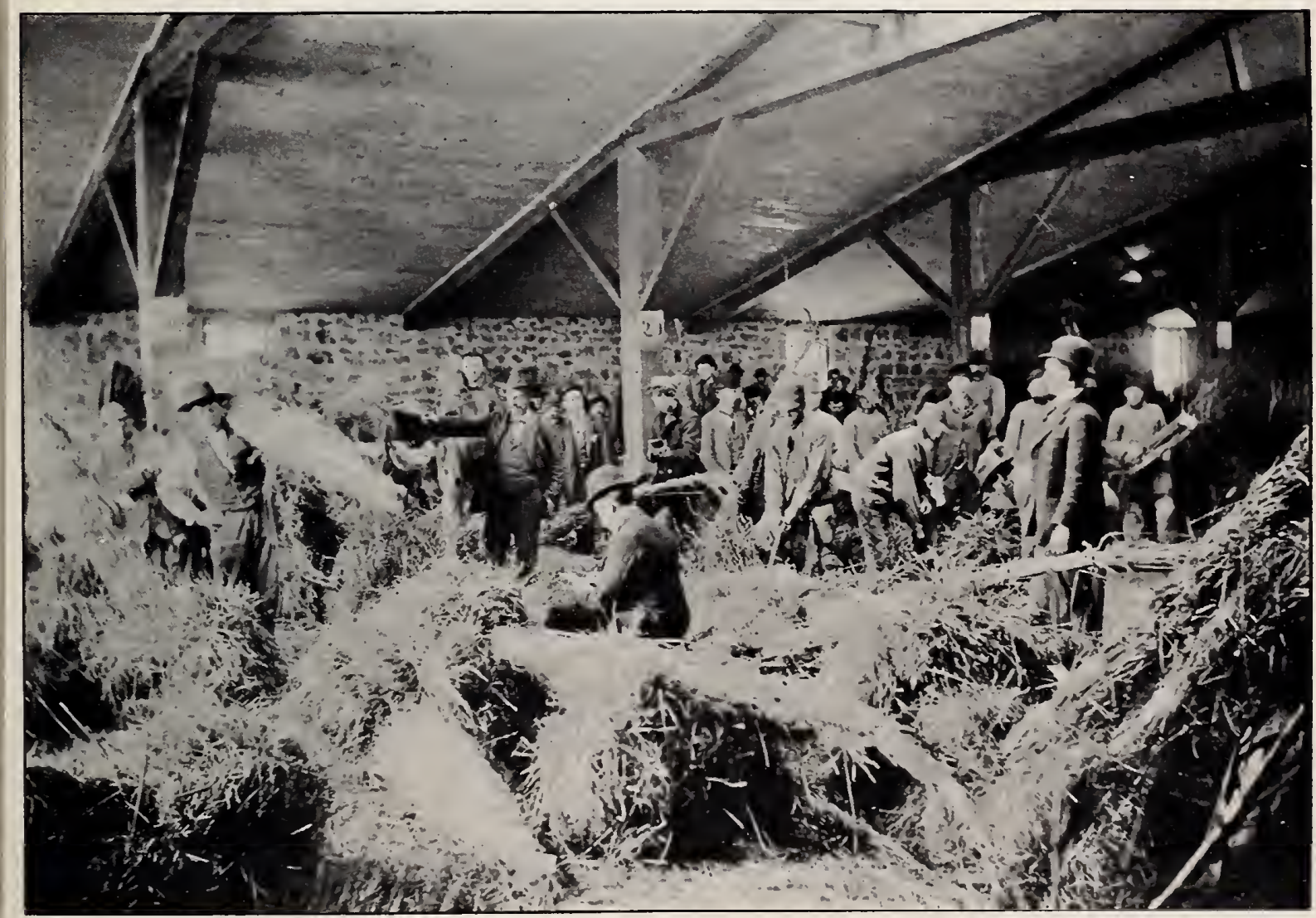




\title{
CLIMBING SHRUBS.
}

\author{
Amphelopsis.
}

AMERICAN IVY, VIRGINIA CREEPER, (Quinquefolia).-A rery rapid growing vine. clinging to any thing it touches. large forked leaves that become rich crimson in the autumn, one of the finest climbers for corering verandas, walls. trunks of trees. etc.

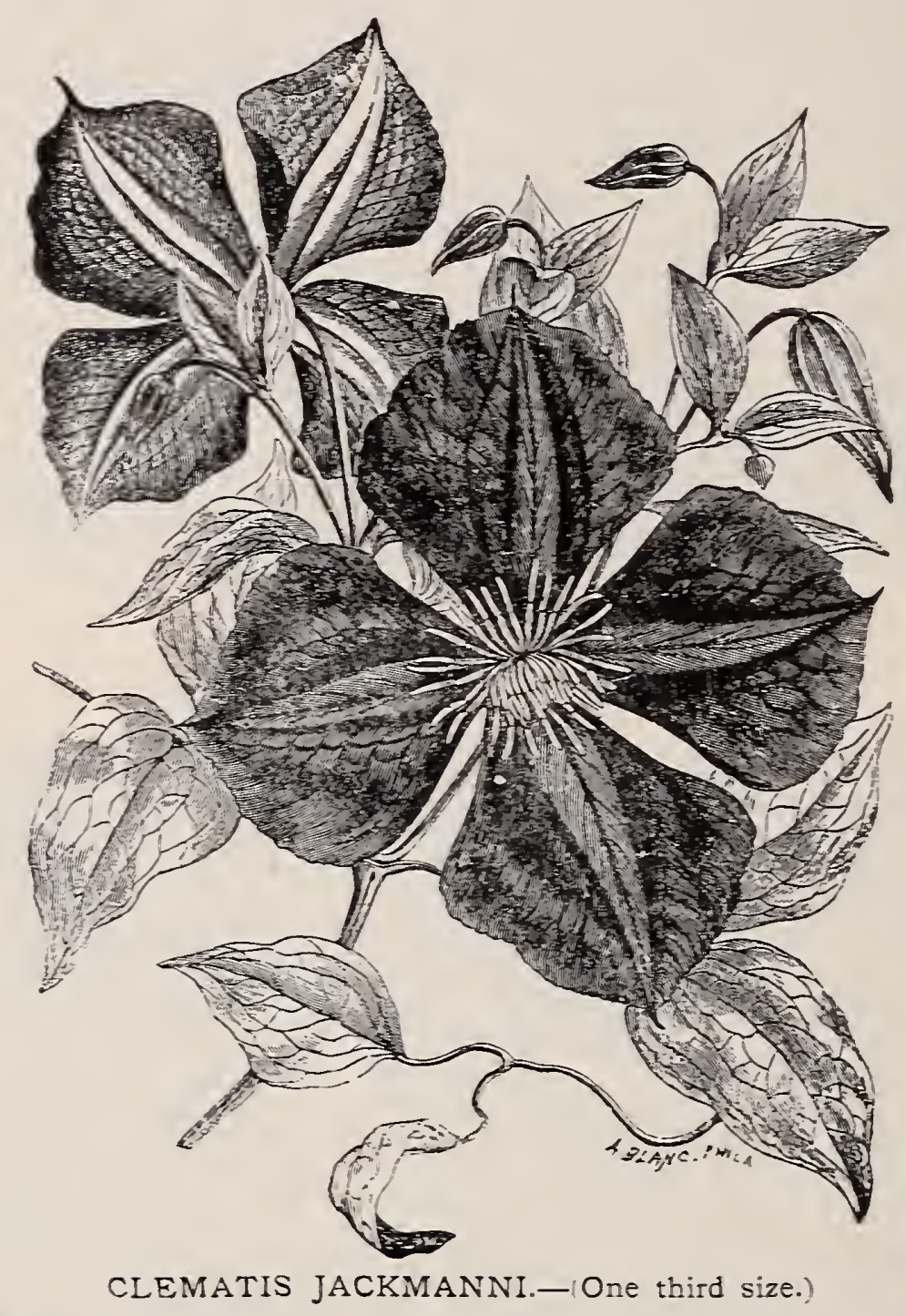

JAPAN IVY, (Veitchii). - Similar to the American IVy, having smaller and more irylike leaves that are of a glossy green. shaded with purple. changing to a brilliant red in the autumn. It clings to the smoothest surface, a beautiful climber. and becom. ing a great farorite.

\section{Begonia, or Trumpet Flower-Radicans.}

A splendid. hardy. climbing plant. large.

\section{Birthworth-Aritolochias.}

TUBE FLOWER OR DUTCHMAN'S PIPE, (Sipho)..A rapid grower. with rery iarge, dark green leaves, and curious. brownish, pipe-shaped blossoms. 


\section{Clematis, or Virgin's Bower.}

This is without doubt the most gorgeous vine for covering arbors, trellises, pillars, rock-work, bedding in masses, etc. They vary greatly in their foliage and flowers, and are adapted to the various uses; it will succeed in any good soil, but best in a ricl,, moist loam. The varieties we name in our list are the finest, perfectly hardy, rapid growers and profuse bloomers

COCCINEA.-A beautiful new variety, with bright scarlet, small, bell-shaped flowers, very choice and attractive.

FLAMMULA.-An old and highly prized variety, fragrant, small, white flowers.

FAIR ROSAMOND.--Bluish white, with an indistinct red bar.

HENRYI.-Flowers large, fine form, beautiful creamy white, vigorous grower and free bloomer.

JACKMANNI.-- The most beautiful and desirable clematis, flowers large, rich, violet purple. A profuse bloomer. See cut.

LUCIE LEMOINE.-Very large, fine form, double white, very showy.

LINUGINOSA CANDIDA.--Very large, grayish white flowers, one of the best.

MADAM EDOUARD ANDRE.--A distinct new variety, lately imported from France, very handsune red.

PRINCE OF WALES.--Deep purple, with a crimson bar through each petal. Very desirable.

RAMONA.-A strong, rampant grower, and free perpetual bloomer. The flowers are very large, often measuring six to seven inches in diameter, and of the most perfect shape. Color rich lavender blue.

STAR OF INDIA.--A very showy, profuse blooming variety, flowers reddish purple: with turkey red bar in the center of each flower leaf.

VITICELLA.-Small, bluish purple flowers.

\section{Honeysuckle-Lonicera.}

COMMON WOODBINE, (Periclimininum).-A vigorous grower and very showy. Flowers red and yellow.

CHINESE TWINING, (Japonica).--Retains its foliage all winter, blooming at intervals. Flowers variegated, yellow and white, fragrant.

HALLIANA, (Hall's Japan).-An acquisition lately introduced from Japan. Is evergreen, flowers pure white, changing to yellow, very fragrant and pleasant. Continues in bloom from June to November. 
JAPAN GOLDEN LEAVED. Aurea Reticulata.- The most beautiful variety of this class of climbers. Leaves of bright green. and golden yellow vines, exquisitely beautiful, fine for bedding. pot culture, or for hanging baskets. perfectly hardy. Will give entire satisfaction.

MONTHLY FRAGRANT, (Belgica), - Sweet scented vellow flowers, very fine, continues in bloom all summer.

S¿ARLET TRUMPET MONTHLY, (Sempervirens).-Strong, rapid grower, blooms all summer.

YELLOW TRUMPET, (Flava).--Very fragrant.

\section{Wistaria or Glycine.}

CHINESE, (Sinensis).-A splendid climber hung with an abundance of pale blue tiongrs in spring and autumn. Very rapid grower.

CHINESE WHITE, (Sinensis Alba.) -.A valuable variet: pale white flowers.

AMERICAN, (Frutescens).-Not as vigorous as the Chinese. Flowers light biue, sweet scented.

I. E. Ilgexfritz' SoNs, Monroe. Mich.

Cloterdale, O=I. 29, i $89 ;$

Dear Sirs. - Enclosed find $\$ 5.16$, the amount of my bill of fruit trees. I would like to get 500 more peach trees from you. as you sent them true to name.

Yours truly,

GEO. REPLAGLE.

I. E. Ilgexfritz Sors, Monroe, Mich.

Milllbrook, Mifch., MaY I3, I895.

Gentlemen,- - The stock has given almost universal satisfaction, and if it continues as it now shows up. you have secured a hold here that will last and be a paying one in the future. I have not seen a tree that is not growing. nor have I heard of one. I can double the trade here this season.

P. S. The amount of the above delivery, si600.

SAMUEL CRUM, Agt.

I. E. Ilgexfritz' Soxs, Monroe, Mich.

LEE, MICH., OCT. 27.

Dear Sirs. - Your stock gare the best of satisfaction, as near as I can find out. I was at Lacota and helped your delivery agent. There was no fault at all found and every one went away pleased. I do not want any better trees than I got.

lours,

J. B. DEWY, Agt.

I. E. Ilgexfritz' Soxs, Monroe, Mich.

Sheborgax, Wis., MaY io.

Gentlemen, - Yours of the 6th received. and as evervthing is done and draft sent yesterday there is nothing for me to do. The trees you sent here were nice and gave good satisfaction. A Rochester firm sold $\$+00$ worth here and they came poorly packed and not half were taken. 


\section{EVERGREEN TREES AND SHRUBS.}

\section{Arbor Vita-Thuja.}

Two to three feet.

AMERICAN, (Occidentalis).-A very beantiful native tree, with flat foliage. A rapid, erect grower, and quite hardy; highly prized for screens and hedges.

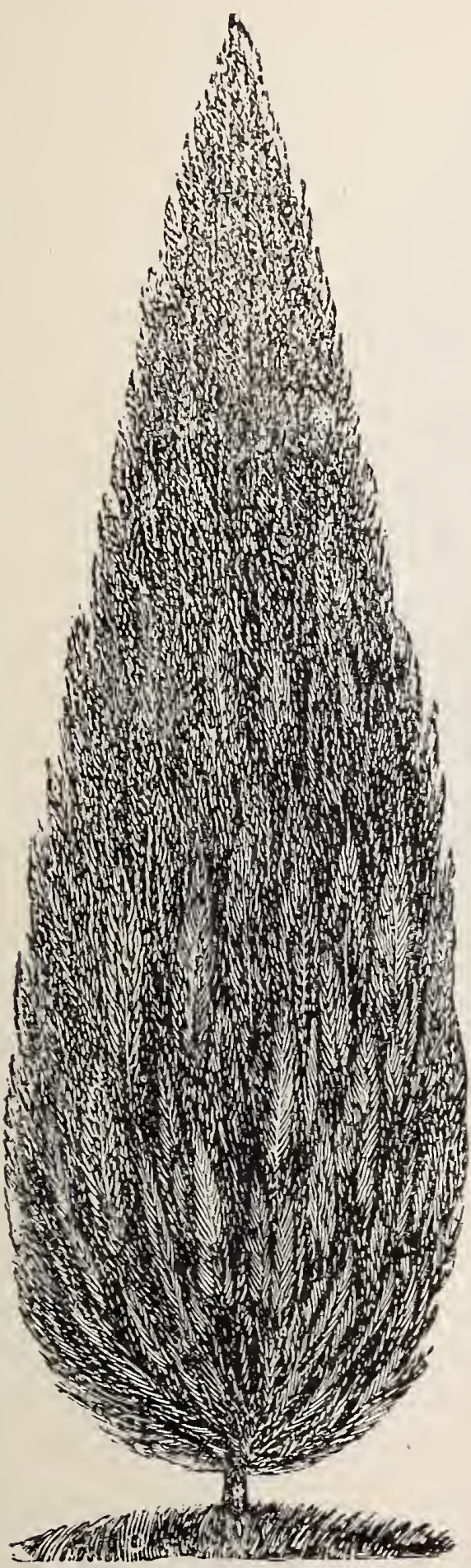

PYRIMIDALIS $\triangle R B O E$ VITE.

COMPACT, (Compacta).- I handsome tree, of a solden lue and globular form, growth rather slow, broad and compact.

ELEGAINTSSIMA. - An elegant variety of small size and upright, regular form, with young foliage tipped with a golden yellow.

GLOBE, (Globossa).--A pretty dwarf tree, very round and compact. Quite a favorite.

PYRIMIDALIS.-- One of the most beautiful varieties, very erect and regular in form, with dark green, compact foliage: very hardy. Should be in every collection.

SIBERIAN, (Siberica).--Very hardy, and holds its color during the winter. Very dense, of regular form, highly ornamenta.

SEMPER AUREA.-A handsome new variety, of small size, with foliage of a golden tint the year around.

TOM THUMB.-A dwarf variety of the American Arbor Vitæ, of very slow growth and compact habit. Valuable for cemeteries, lawns, etc.. where the large growing trees may not be admissible.

\section{Fir-Picea.}

Two to three feet.

BALSAM, OR AMERICAN SILVER, (Balsamea).- A very regular, symmetrical tree, leares dark green above and silvery beneath. Grows rapidly, and is "ery hardy. 


\section{Juniper-Funiperus.}

IRISH, (Hibernica).-Very erect and tapering in its growth, forming a column of deep green foliage. A pretty little tree or shrub, and, for its beauty and hardihood, is a general favorite.

SWEDISH, (Suecica).--Similar to the Irish, though not so erect, with bluish green ioliage, of a somewhat lighter color than the preceding, forming a beautiful pyramidal small tree.

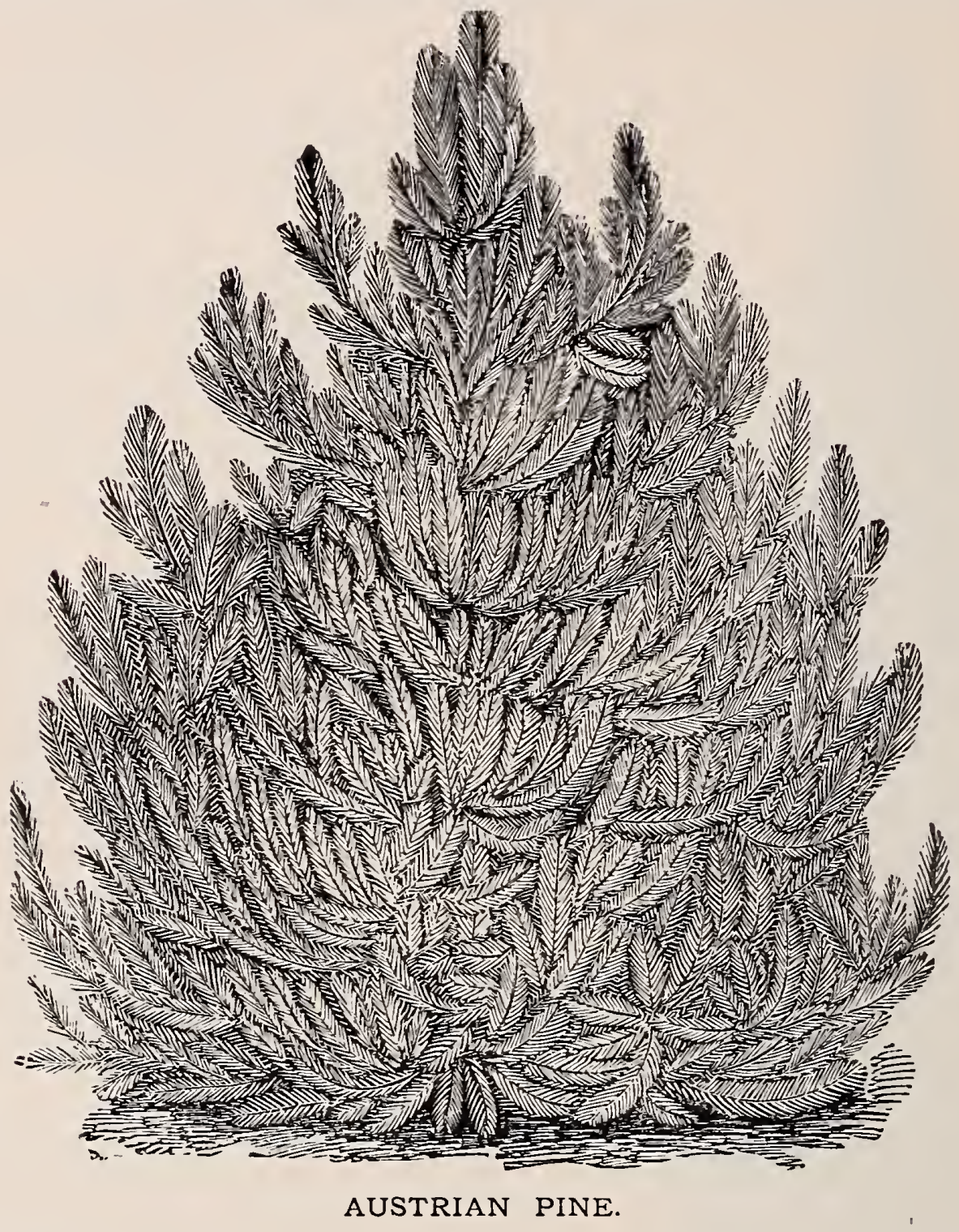

SAVIN, (Sabina).--Spreading lawn tree, with very handsome dark green foliage, very suitable for lawns and cemeteries. This can be pruned into any desirable shape, and made highly ornamental.

VIR'INIAN, (Virginiana).-The Red Cedar. A well known tree, with fine deep green foliage, variable in its growth, suitable for ornamental hedges.

\section{Pine-Pinus.}

Two to three feet.

AUSTRIAN, (Austriaca).-A very rapid grower and conspicuous tree; leaves long, stirt, and dark green; hardy and robust. One of the most valuable evergreens. 
SCOTCH, (Sylvestris).--A thrifty, rapid growing tree, with rather short foliage of a bluish tinge. Thrives even on the poorest soils.

WHITE, (Strobus).--One of the most beautiful and delicate of the native pines; leaves light green, in clusters of five.

\section{Rhododendron-In Variety.}

These are the most magnificent of all evergreen shrubs, with rich green foliage and superb clusters of showy flowers. They flourish best in a peaty soil and somewhat shaded situation, and they will repay all the care that may be bestowed in preparing a bed suited to their wants.

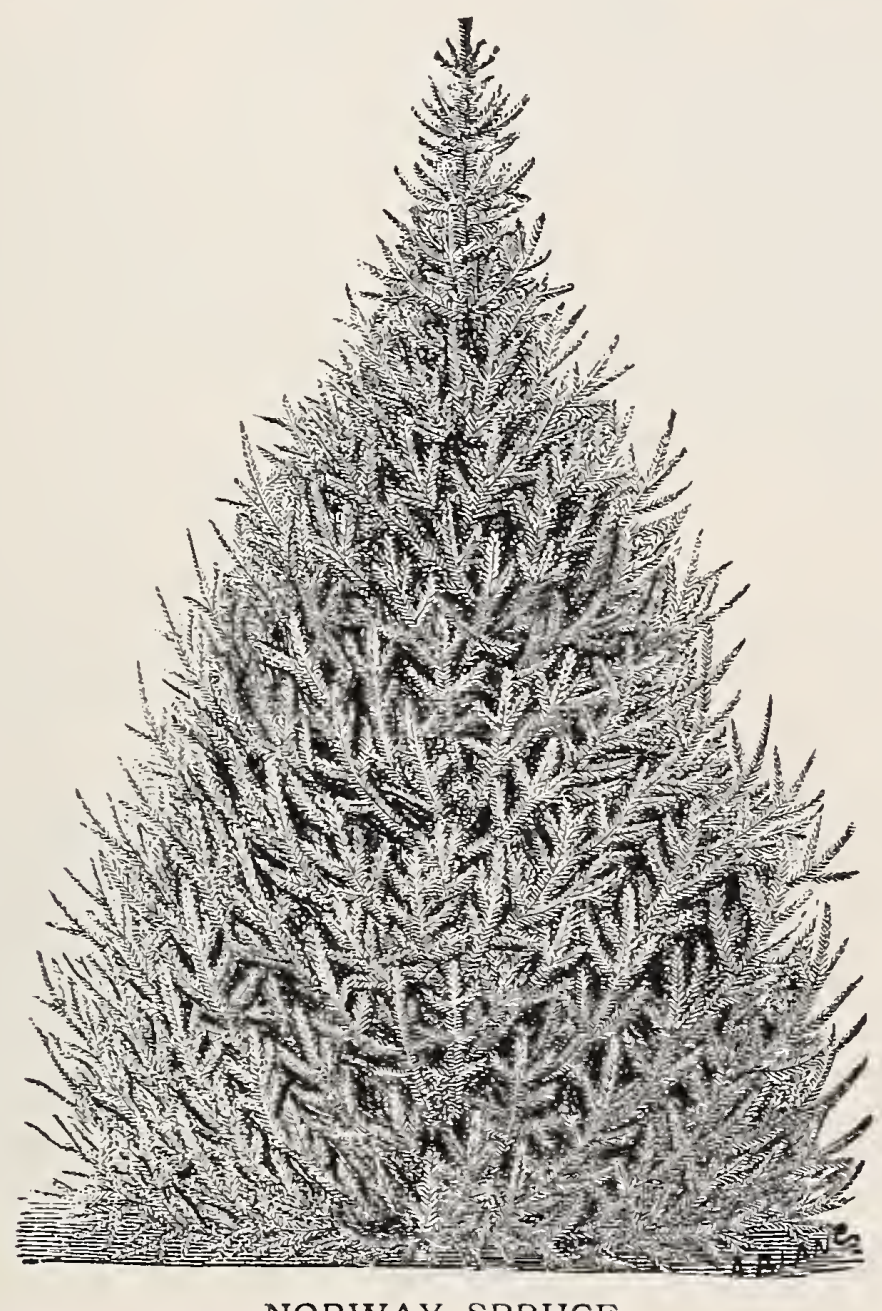

NORWAY SPRUCE.

Spruce Firs-Abies.

NORWAY, (Excelsa).--An elegant, lofty and graceful tree, with drooping branches, bright green foliage, and quite pyramidal. It is decidedly the most hardy, ornamental and interesting of the evergreen tribe. See cut.

COLORADO BLUE, (A Pungens).--One of the most distinct and striking of all the spruces. A rare and beautiful tree, with foliage of a rich blue, or sage color. A free grower and perfectly hardy.

HFMLOCK, (Canadensis).--One of the most beautiful and distinct of this class of trees. Tile foliage is delicate, and the branches are gracefully drooping.

WHITE, (Alba).--A native tree of medium size, regular, compact. pyramidal form, with silvery green foliage, very hardy and beautiful. 


\section{HEDGE PLANTS. \\ $\longrightarrow$ \\ FOR ORNAMENT, SCREENS, SHELTER AND DEFENSE, \\ EVERGREENS. \\ Arbor Vitæ.}

AMERICAN.-This plant is deservedly very popular for ornamental hedges and screens. It is perfectly hardy and easily transplanted, and by a little attention soon forms a beautiful and dense hedge.

SIBERIAN.--This variety is admirably adapted for dividing lines between lawns or gardens, or for hedges along streets. It is of rich deep green color, which it retains throughout the year. Compact in gruwth and very hardy.

TOM THUMB. - This is one of the most desirable plants for low, ornamental hedges and borders.

\section{Box Dwarf.}

In mild climates this plant is considerably used for edgings and borders, with very pretty effect.

\section{Hemlock.}

From its very graceful habit and fine rich color, is very popular, but is not as hardy, or as well adapted to all soils as the Arbor Vitæ.

\section{Norway Spruce.}

This is the most valuable evergreen for screens or shelters, is of rapid, high, compact growth, soon forming one of the best wind-breaks. It is also very valuable and beautiful for ornamental hedges, and it bears the shears well and can be kept low a great many years by annual trimming.

\section{Deciduous.}

HONEY LOCUST.- One of the most valuable plants for a strong and defensive hedge. It is of vigorous growth, very hardy, succeeds with ordinary care, can be grown in any desired form, and is sufficiently thorny to be impenetrable.

JAPAN QUINCE.-By giving this plant care it forms a beautiful hedge, and is especially ornamental in the spring, when it is covered with bright crimson flowers.

OSAGE ORANGE.-This is a valuable and popular plant for hedges. It is of rapid growth, and in three years forms a perfectly impenetrable hedge.

PRIVIT.-The privit is very appropriate for ornamental hedges or division lines, and is of very easy cultivation.

SPIREAS.-This shrub is finely adapted to form ornamental hedges. It is of low growth and produces a very pretty flower. 


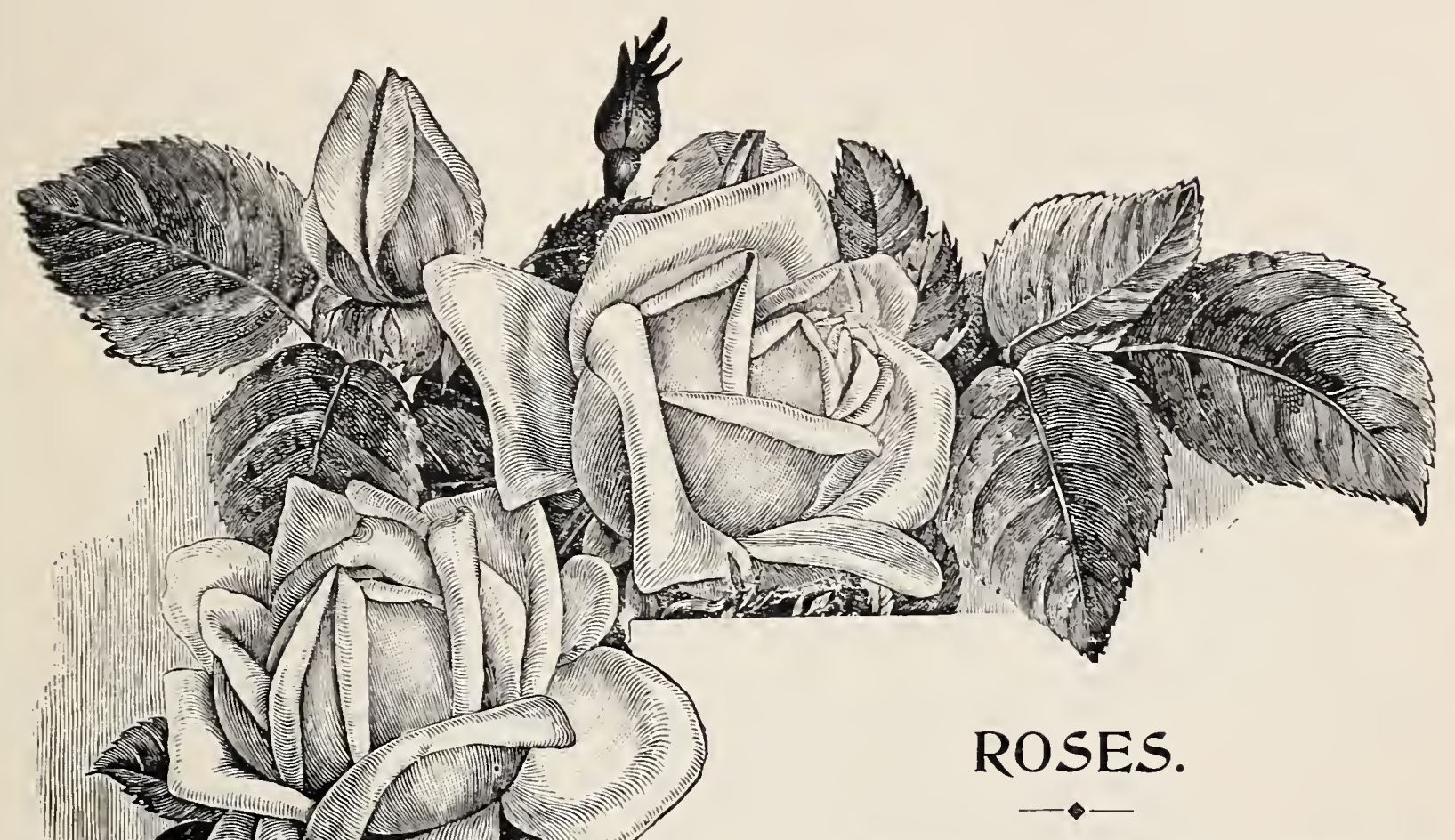

The Rose, "The Queen of Flowers," is justly one of the most popular in cultivation, and none gives better satisfaction to the lover of beautiful flowers when properly treated.

To obtain richness and lixuriance of foli. age, and well developed flowers, it must receive good cultivation. With good treatment it will yield a varied, profuse and beautiful display of flowers, from June to Norember.

But to obtain the most satisfactory results they should be planted in well drained, rich, deep, loamy soil. If not naturally rich and deep, it should be made so by trenching or spading to the depth of two feet and incorporating with it well prepared compost of rotted manure. For winter protection. and to keep the soil in fine condition, an application of compost should be given them late in Autumn, and spaded into the ground the following Spring.

Pruning is necessary to maintain a good shape, and to secure a good supply of young wood. This should be done in the Spring; the latter part of March is the best time. This is done by cutting off the previous year's growth to within three or four buds. The remaining buds will then throw out vigorous branches, and in due season produce a splendid bloom. This mode of pruning, lowever, is not applicable to climbing roses until the desired surface or space is covered.

\section{Hybrid Perpetual Roses.}

THE perfect hardiness, free blooming quality, blooming at intervals from June to November, the perfect shape and rich colors of the flowers, varying from pure white to bright crimson and dark purple, together with the fragrance of nearly all varieties, combined to make the Hybrid Perpetual Roses the most beautiful and desirable class in cultivation. 
To obtain the best results it should be planted in a rich, deep, well drained soil. It requires an annual pruning, which should be done in the spring before the buds start. It is greatly benefitted by an application of long strawy manure placed around the stem to the $\mathrm{s}^{-}$,ace of several feet.

BELLE de NORMANDY.-Purplish red in color, bell shaped. a profuse bloomer.

BEAUTY OF WALTHAM.-Beautiful bright crimsom, very large and full, a free bloomer and deliciously perfumed.

BARON de BONSTETTEN.--A handsome dark rich velvety red rose, very double and full, fragrant. A splendid sort.

COQUETTE des ALPS.-Pure white, sometimes shaded with a blush, large and full, a very profuse bloomer. One of the finest.

COQUETTE des BLANCHES.--Flowers of medium size, full and handsome. Pure white, sometimes slightly tinged with pink. One of the hardiest and finest of the white roses. A very free bloomer.

CAROLINE de SANSAL.-A clear flesh color, with fine blush center, large and full, very desirable.

EMPRESS OF INDIA.-A most beautiful deep red rose, passing to a dark, rich velvety maroon. Flowers large, very double and full. Hardy, free bloomer, very desirable.

EARL OF DUFFERIN.-One of the finest roses of recent introduction. Rich brilliant velvety crimson shaded with maroon. Flowers large, very full and finely formed. A vigorous, healthy grower and free bloomer.

GENERAL WASHINGTON.--Brilliant rosy crimson, large and double, very rich and beautiful, a free and constant bloomer. One of the most satisfactory roses for general planting.

GENERAL JACQUEMINOT.-A brilliant crimson scarlet, very showy and effective Good grower, free bloomer, and a general favorite.

JOHN HOPPER.-Rose with crimson center, splendid form, fragrant and very desirable. See cut.

JULES MARGOTTIN.--A light brilliant crimson, large, full and beautiful, a splendid old sort.

LA REINE.-Bright rosy pink, very large, double and sweet, one of the best. Wel. named, "The Queen."

LORD RAGLAN.--Fiery crimson, shaded with purple, large and finely formed. A superb rose and a vigorous grower.

LA FRANCE.-A very elegant rose, beautiful silvery bush, extra large and full, exquisite, a constant and profuse bloomer.

MARSHALL P. WILDER.-Handsome new rose, flowers large, well formed, bright cherry carmine, very fragrant, vigorous grower, hardy and profuse bloomer, continu. ing late.

MADAME PLANTIER. - Pure white, large and double, blooms abundantly in clusters, very fine hardy rose. 
MADAME CHARLES WOOD.--Deep rosy crimson, sometimes brilliant scarlet, very large and fine form. An early, constant and free bloomer. One of the finest roses ever introduced.

MAGNA CHARTA.--Bright, rosy pink, flushed with carmine, very large, full and double, fragrant.

PAUL NERON.-Beautiful dark rose color, extra large, very double and finely formed, very vigorous.

VICTOR VERDIER.-A splendid sort, rose color, shaded with bright carmine, large, very double, full and fragrant.

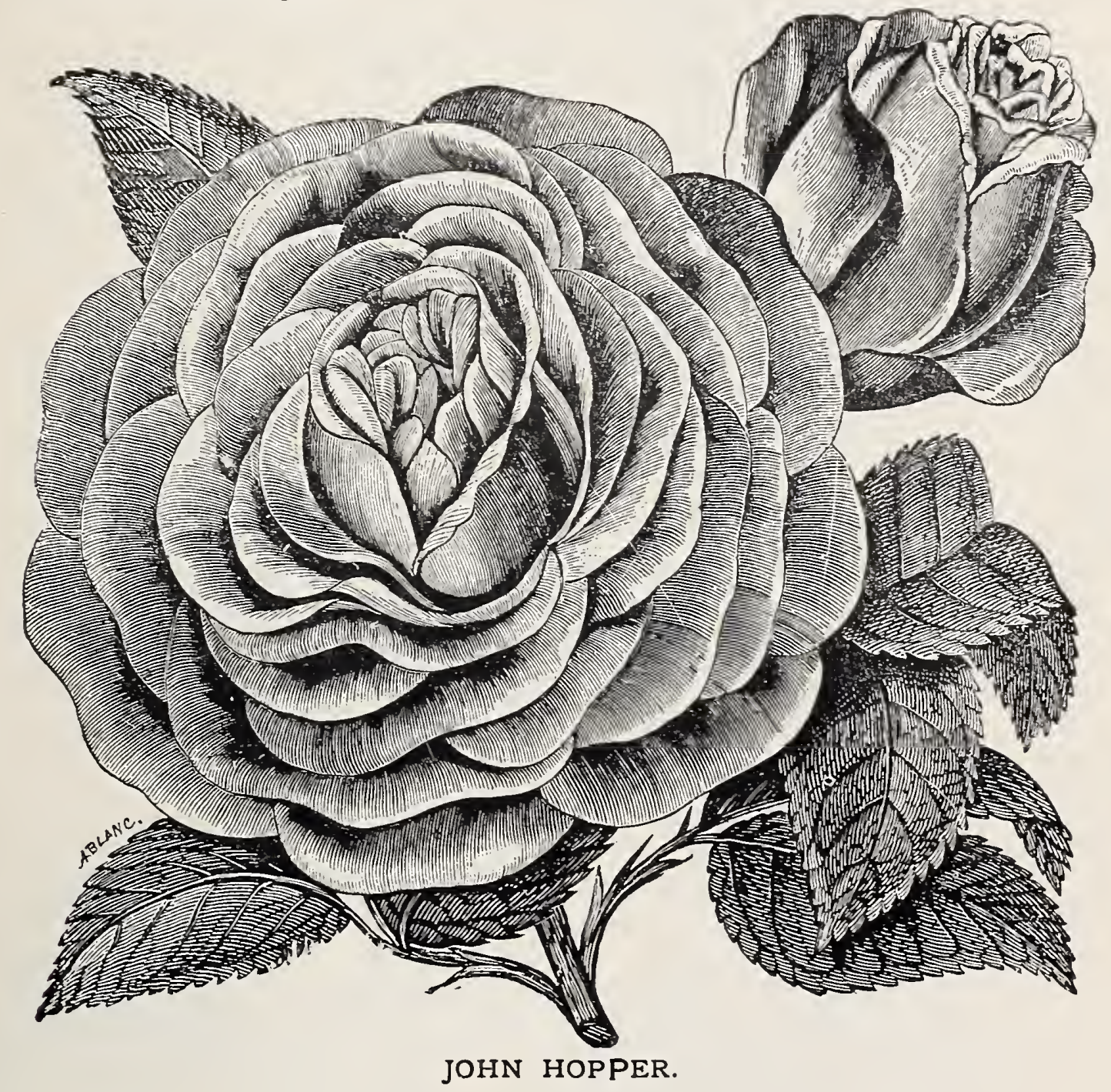

\section{Bourbon Roses.}

THis class of roses blooms continually during the whole Summer and Autumn, but in Autumn, or from the middle of August till November, they display their greatest beauty and profusion of flowers. They are also fine for Winter blooming in pots. They are of vigorous growth, rich, luxuriant foliage, and bloom in large clusters, flowers fragrant. Require slight protection in Winter.

APPOLINE.-Light pink, double and compact, a great bloomer.

AT.RMOSA.-Light rose, full and double, blooms profusely in clusters. One of the best.

LOUIS ODIER.--Fine bright rose, large, full and free bloomer.

QUEEN OF THE BOURBONS. -Fawn colored rose, beautiful and free. 


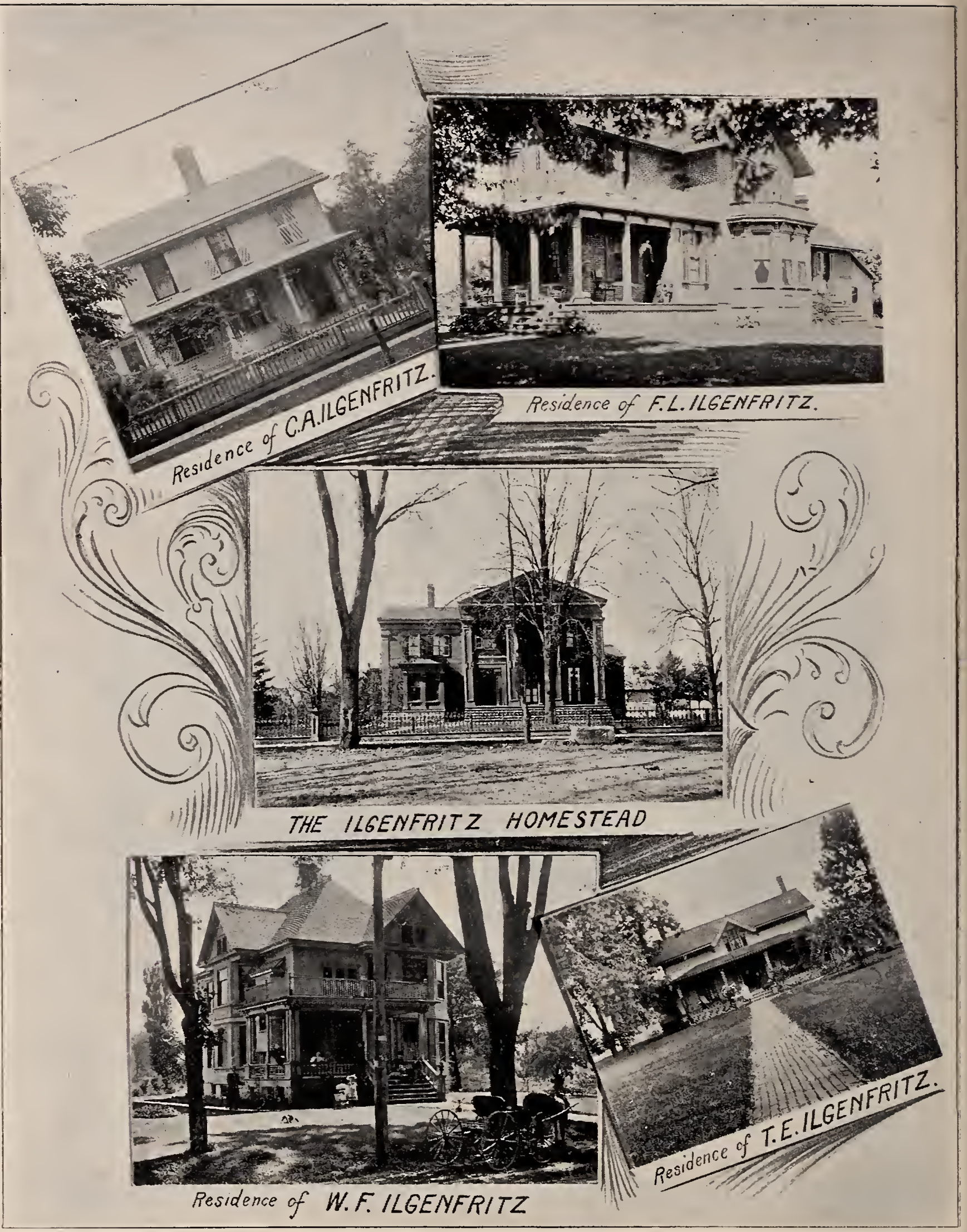




\section{Climbing Roses.}

Among these beautiful climbing plants, the Prarrie Roses rank first. The perfect hardiness of this class of roses, their strong growth and luxuriant foliage, adapt them for covering arbors, walls. trellises, and unsiglitly objects, which, together with their inmense clusters of beautiful flowers. commend them to all lovers of the beautiful. They requirc $\Rightarrow$ but little pruning, except thimning out weak or dead branches.

BALTIMORE BELLE.-Pale blush, nearly white, very double, flowers in beautiful clusters, one of the best white climbers.

GEM OF THE PRAIRIES.-A valuable Hybrid. It is a cross between Marl. Laflar and Queen of the Prairie, bright red blotched with white, large, very double and fragrant.

GREVILLE OR SEVEN SISTERS. - Vary in color from blush to crimson, bloom in large clusters.

QUEEN OF THE PRAIRIES.-Bright, rosy red, striped with white, large and cupped, most beautiful and valuable of the class.

RUSSEL'S COTTAGE._Rich crimson, medium size, very double and full, blooms abund. antly.

\section{Moss Roses.}

THis division of roses embraces many of the most desirable qualities. The fine mossy buds. large fragrant flowers and perfect liardiness, make it a nniversal favorite. It is benefitted by an application of well rotted manure, and a moderate pruning.

COUNTESS OF MURINAIS.-Pure white, large, very vigorous, one of the best white Mosses.

CRESTED (Cristata).-Distinct rose. fine, curiously crested buds.

GLORY OF MOSSES.-Pale rose, vcry large, fuil and beautiful, very mossy and fragrant One of the finest.

HENRY MARTIN. - Finc rosy pink, large, very sweet and mossy

LUXEMBURG.-Clear, deep crimson, large, very sweet and mossy.

PERPETUAL WHITE.-Pure white, double. beautiful, rigorous.

RAPHAEL.-Pinkish white, shaded with rose. A splendid rose.

SALET - Bright rose, blush edges, large, prcfuse flowering. An elegant Moss.

\section{Tea Roses.}

To this division helong the roses so justly celebrated for their delightful frag!ance. -....cacy of colur and beauty of buds. Thcy are free bloomer's, and rather tender to stand out during the winter without protection.

DJCHESS OF EDINBURG.-Brilliant vermillion, shaded with a rich velvety maroon, large. Delightful fragrance.

ETOILE de LYON.-One of the hardiest of teas for outside planting. Chrome yellow: deepening in the center to a pure golden yellow. Deliciously scented. 
GLORIE de DIJON.-Rich yellow with salmon shade in the center, large and double with an exquisite fragrance. One of the finest in every respect.

MARECHAL NEIL.-Large, beautiful deep yellow, very sweet. The finest of all yellow roses.

NIPHETOS.-Yellowish white, verv large and double, buds remarkably large and fine, delightfully fragrant.

THE BRIDE. - Said to be one of the best pure white roses ever introduced. The buds and flowers are very large, double, well formed, and delightfully perfumed, free bloomer.

SAFRANO.-Bright apricot yellow, changing to orange, sometimes tinted with rose, very profuse blcomer, one of the best.

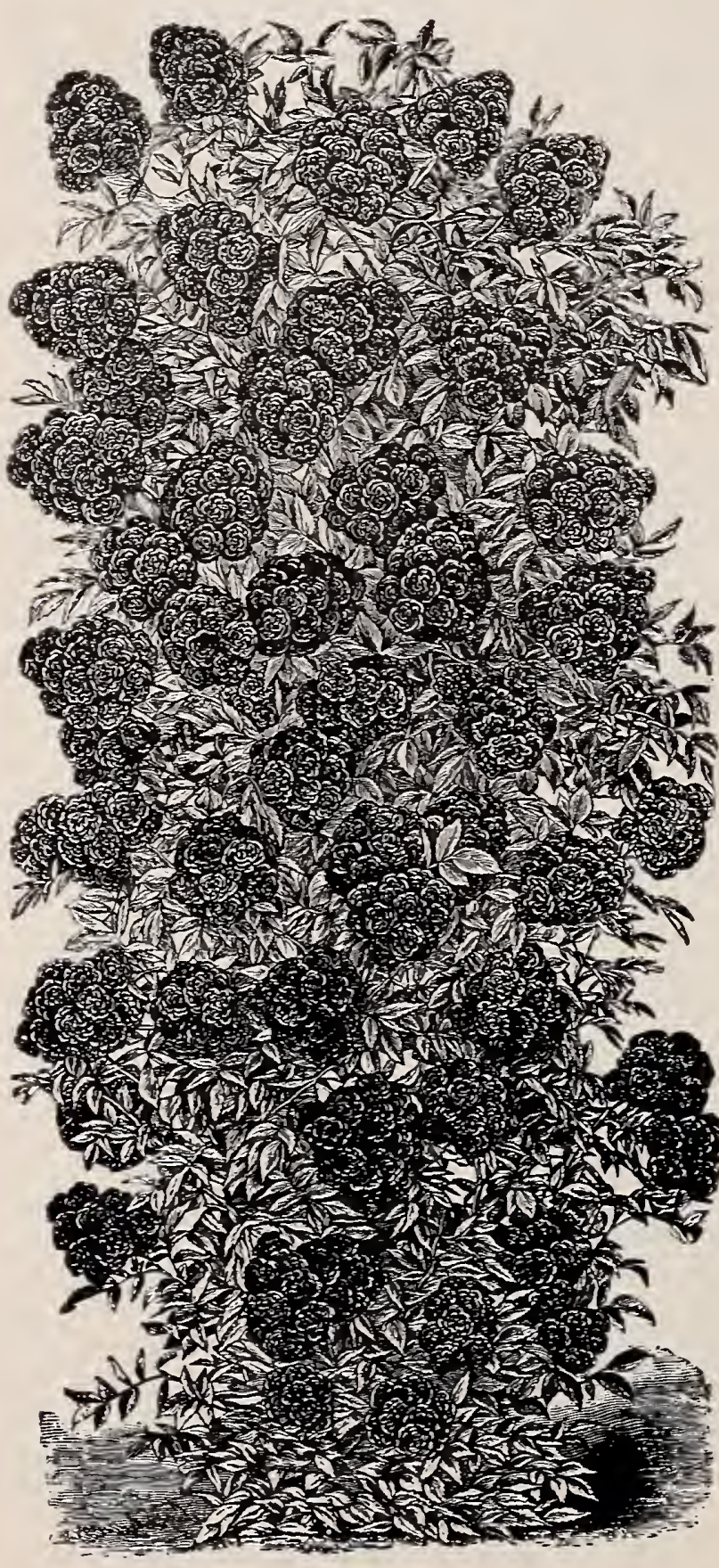

CRIMSON RAMBLER.
SUNSET.-One of the most beautiful varieties recently introduced, flowers large, finely formed and delightfully perfumed, color rich golden, shaded with deep crimson, strong grower and free bloomer.

\section{The New Climbing Polyantha Rose.}

CRIMSON RAMBLER.-The Gem among twenty years introductions. This remarkable Rose comes to us by way of England, fronı Japan, the home of so many of our most valuable flowering plants. It was first brought to England by the engineer of one of the steamships touching at Japanese ports, and finally came into the hands of a leading horticulturist who paid $\$ 2,500$ for it. $\mathrm{He}$ at once commenced propagating largely from it and exhibited the flowers at various shows in England and on the continent. It was awarded numerous first-class certificates, and from the National Rose Society (England), the Nitional Horticultural Society (France) and at the International Horticultural Exhibition (England), it received Gold Medals, a certificate being regarded as wholly inadequate to indicate the merits of the variety.

ITs HaBIT of growth is extremely vigorous, young plants often making shoots of eight to ten feet in a season. It is therefore a most desirable variety for training upon walls, trellises, etc., but can also be very advantageously grown as a pillar rose (fastened to a stake), or by pruning back can be kept in bush form. It is also very successfully grown as a pot plant and its perfect adaptability to all of these uses adds much to its value. 
The FLowers are a rich glowing crimson with none of that objectionable purplish tint so common in crimson roses, and remain on the plant in perfect condition, with their freshness and beauty unimpaired, for more than two weeks. They are borne in immense pyramidal trusses of from twenty to forty blooms, the individual flowers measuring from one inch to one and one-half inches in diameter. As can be readity innagined, the effect prodnced by a large plant closely covered with these great crimson trusses is something magnificent and it is much enlianced by the glossy green foliage which makes a splendid background for the flowers.

Its Hardiness has been thoroughly tested for two seasons in England by planting in the most exposed situations, and this past winter it has, in this country, successfully with. stood a temperature of eighteen degrees below zero, without protection. It may therefore be depended upon to succeed in the most severe climates.

We cannot say too much in praise of this wonderful new Rose, and our customerc will make no mistake in purchasing it at once. It will prove a revelation of beauty to all wh. plant it.

YELLOW RAMBLER.--The only yellow hardy clinibing rose. It has been thoroughly tested and found to successfuly withstand without protection a continued temperature of zero and below. It is similar to Crimson Rambler in manner of blooming, the flowers being in immense clusters and having the same lasting qualities, remaining in bloom from three to four weeks. The plant is even freer in growth than Crimson Rambler and soon makes a fine showy specimen.

WHITE RAMBLER.-In habit of growth, foliage, manuer of bluoming and shape of flower this is identical with Crimson Rambler, differing only in color.

\section{Tree Roses.}

Tree Roses are grafted on hardy rose stalks four to five feet high, are tree shaped, and when in full bloom are beautiful; making handsome plants for the lawn. In this shape we offer only the Hypbrid Perpetual or hardy class. We have them in various colors.

I. E. Ir.genfritz' SONS, MonroE, Mich.,

Pentwater, Mich., Oct. 24, is9g.

Dear Sirs, - The bill of trees arrived O. K. I was out to Crystal Valley when my man was planting them, they are certainly fine trees. I am done planting trees for the present and I thank you for the good care you have given my order for the past 3 years.

Very truly yours,

I. C. HARWOOD.

I. E. Il.genfritz' Sons, Monroe, Mich.,

JASPER, MICH., Oct. I899.

Dear Sirs, - I received trees etc., on 2 Ist inst all right for which please accept my heartfelt thanks. They are all fine. I am more than pleased.

Yours very respectfully, Charties A. Monroe.

Albion, Mrch., May i6th, I898.

I. E. Irgenfritz' Sons, Monroe, Mich.,

Gentlemen,-I am much pleased with the quality of the stock you sent me. The trees all through are the finest I have ever received or handled.

Yours respectfully,

S. L. Cook.

ELGIN, Ir.I. Nov. 2I, IS99.

I. E. Ilgenfritz' Sons, Monroe, Mich.,

Gentlemen,-The goods you sent here this Fall were splendid, I am happy to say.

Respectfully yours,

H R. BATES. 


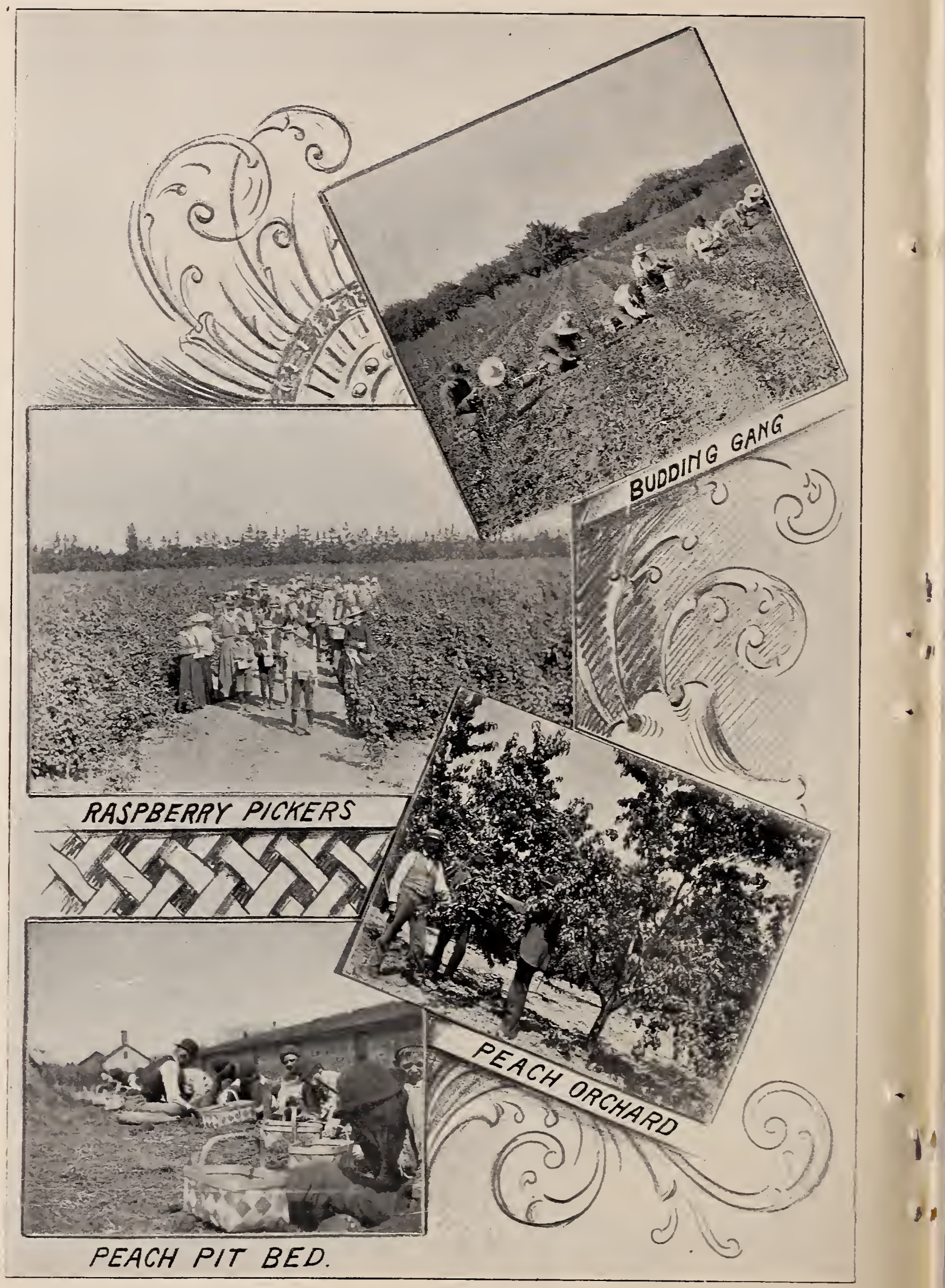




\section{MISCELLANEOUS PLANTS, BULBS, ETC.}

\section{Dahlias.}

DA:ilias are among the most magnificent flowering plants, producing a profusion of flowers of beautiful form and brilliant colors. They may be had in bloom for three or four months. Their culture is simple and easy. Plant in rich, deep soil, about the first of June, or as soon as danger from frost is past. Plant about three feet apart each way. In dry weather they are greatly benefited by a heary mulching of leaf rot or short manure.

ViNTERING.--After frost has destroyed the bloom, cut the stem off about three inches from the ground, and with a spade lift them from the bed. Expose to the sun till well dried, then store in a dry room or cellar, where they will not be reached by frost.

We are prepared to furnish the most popular and best varieties.

\section{Tree Peonies.}

THIs is a very superior class of plants, hardy and well adapted to this climate. They bloom in May and June, producing large flowers and various colors, white, rose-color, etc., and of a delicate, pleasant fragrance. Succeeds best in rich, sandy loam.

BANKSII.--Rosy blush with purplish center. Large and fine.

PAPAVERACEA, (Poppy Flowered).--Bluish white witl deep crimson center, showy.

\section{Herbaceous Peonies.}

A BEAUTIFul family of hardy plants, deserving of more general cultivation than they receive. When once planted and established they receive no special care, and yet proInce large, beautiful flowers of different colors, some of which are quite fragrant.

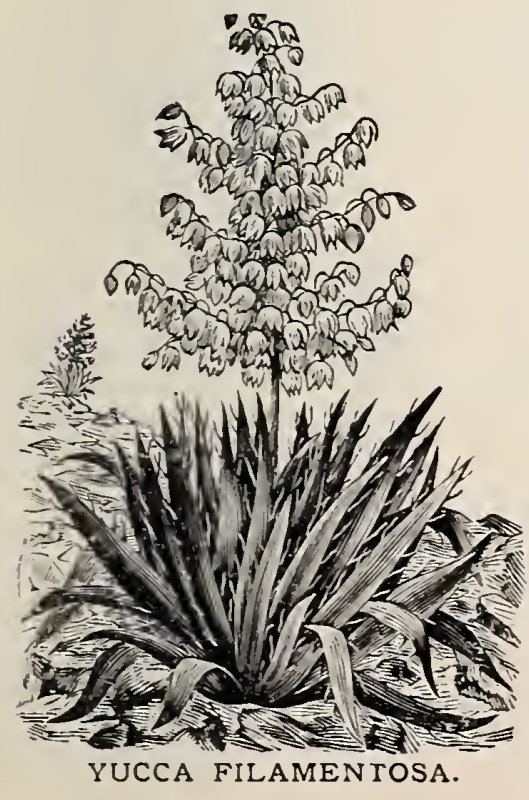

DIVEASIFLORA.-Outside petals white, inside fringed. anemone flowered, foliage dark.

HUMEII.--Rosy purple, very large and showy. blooms very late.

POTTSII.-Dark purple crimson, very distinct and fine.

ROSES FRAGRANS.--Deep rose, double, large and fragrant.

\section{Yucca Filamentosa-Adam's Needle.}

A coxspicuous tropical looking plant, with long, narrow leaves. The flower stalk rises from the center about three feet, and is covered with creamy white. bell-shaped flowers. 


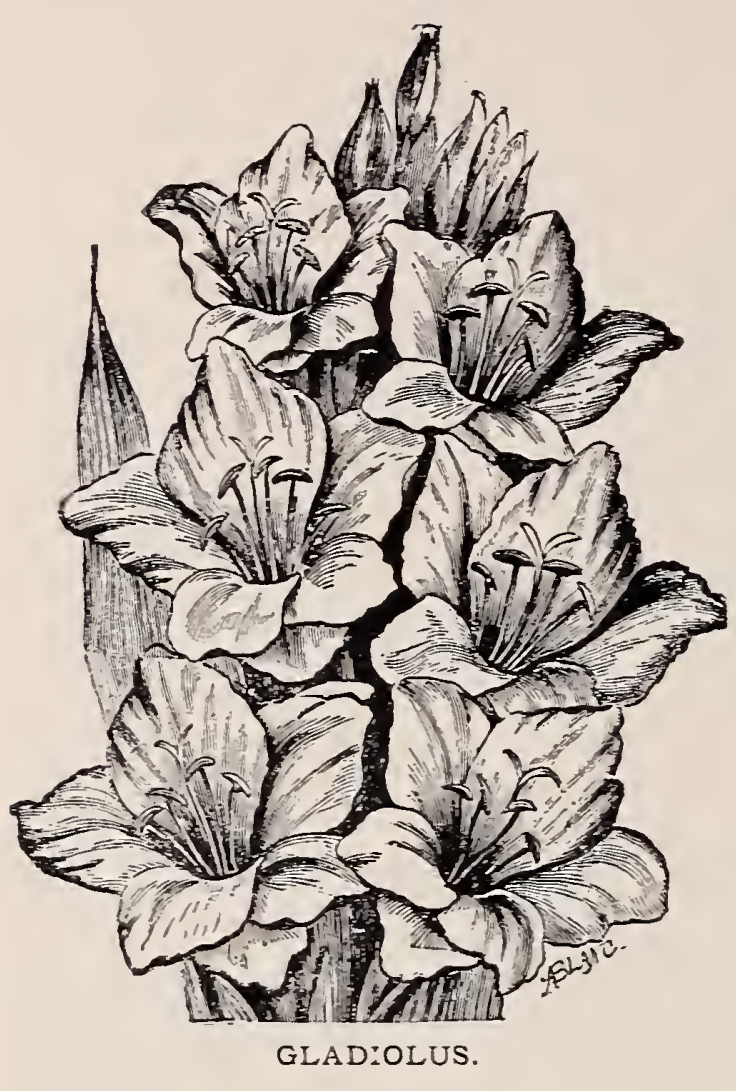

\section{Gladiolus.}

GLADIOLLS are universally admired for their magnificent flowers, which are of the richest colors. To obtain a succession of bloom, they should be planted fortnightly, from the first of April to the beginning of June. They will then produce a succession of blooms from July to November. Plant in good, dry, sandy loam, from two to four inches deep, according to size of bulb. In Autumn, when the leares turn yellow, the bulb is sufficiently ripe to take up. After taking up, they should be sun dried for a day or two, then put in a dry cellar and kept from the frost.

WE have a fine collection of these bulbs, and can furnish the finest sorts in cultivation.

\section{Lilies.}

THE Lily has always been deservedly a fav. orite. They are most graceful in lines, brilliant in delicacy of color, and of delightful fragrance. They succeed best in a dry, rich soil, where water will not stand in winter. After planting they require very little care. and if not disturbed for several years, they will bloom more freely than if taken up annually.

AURATUM, (Gold Banded).-Flowers very large, of a delicate white color, thickly dotted with rich, dark crimson spots, with a bright golden band through the middle of each petal.

CANDIDUM.--Large pure white, fragrant. A handsome and desirable rariety.

HARRISI, (Bermuda Easter Lily).-Flowers large, trumpet shape. with a delightful fragance. A remarkable free bloomer, valuable for forcing or out-door planting.

LONGIFLORUM.--Large. white, trumpet-shaped, borne in large clusters, very fragrant.

LANCIFOLIUM ALBUM.-Pure white, a very delicate and beautiful variety.

LANCIFOLIUM RUBRUM.-An exquisite variety, flowers white and dotted all over with crimson spots, free bloomer.

TIGRINUM, (Double Tiger Lily).-Bright orange scarlet, with dark spots.

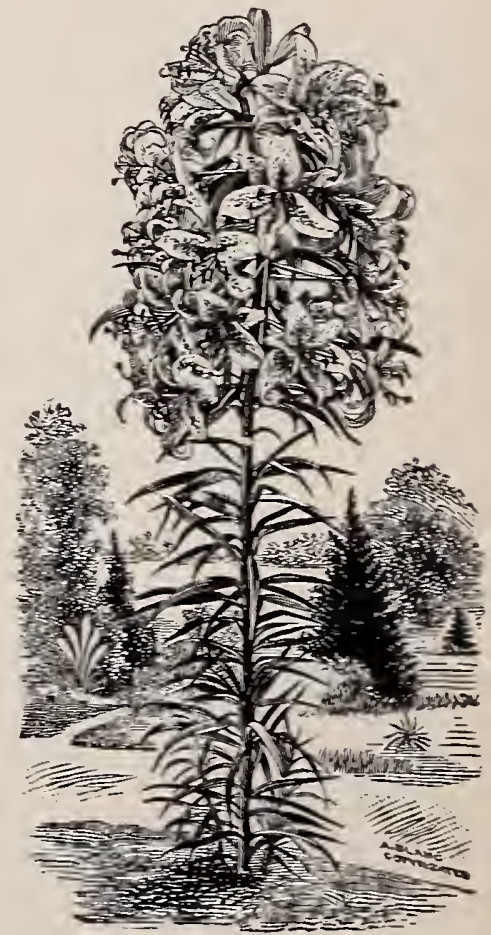

AURATUM. 


\section{Tuberoses.}

One of the most beautiful Summer flowering plants, producing spikes from two tc three feet high, of double, pure waxy, white flowers, delightfully fragrant. May be kept in bloom for a long time by planting from the first of April to the first of June. Very desirable for bouquets or baskets. We can supply the best varieties.

\section{FLOWERING BULBS FOR FALL PLANTING.}

CROCUS.--In various colors. Best imported bulbs.

HYACINTHS.-Fine mixed sorts, by colors.

NARCISSUS.--Fine varieties.

TULIPS.--Single and double, our selection.

\section{Golden Glow.-Double Rudbeckia.}

A hardy perennial growing six to seven feet high and producing hundreds of bright golden flowers, two to three inches in diameter, on long graceful stems, forming immense heads of bloom. Fine for cut flowers. Should be planted in every garden; for when once well established will furnish an endless amount of flowers. Can be grown anywhere wi h vary little care.

I. E. Irgenfritz' Sons, Monroe, Mich.,

Fisher STATION, Mich., Oct. 23, i897.

Dear Sirs, - I have just received my Nursery Stock and the same is in elegant shape. Am well pleased with your stock and the way of doing business.

Yours very truly,

Jacob Brudi, Jr.

Farmington, Mich., May, i6th, i899.

Dear Sir,-Yours of the 3 d inst just received today. The stock was all right and is starting nicely. Will send you the money in a day or two. I shall want to place an order with you for next Spring`s Setting.

Yonrs respectfully,

A. B. Beach

Gypsum, Ohio, Sept. 5th, ISg9.

I. E. Ilgenfritz' SoNs, Monrof, Mich.,

Gentlemen,-Much to the satisfaction of the Growers, the Peace crop is yielding much better than was expected early in the Season. The Elberta Orchard purchased of you four years ago is turning off some of the finest fruit I ever saw.

Yours truly,

B. H. Elwell.

I. E. ILGENFRITZ' SoNs, MoNRoF, Mich.,

Farmington, Mich., Apr. is, is97.

Dear Sirs, - I wish to acknowledge the receipt of my trees that came yesterday in good order. They are very fine and I am highly pleased with them.

Yours very respectfully,

E. IT. PARKER. 


\section{N D EX.}

APPLES $\ldots \ldots \ldots \ldots \ldots \ldots \ldots \ldots \ldots \ldots \ldots \ldots \ldots \ldots \ldots \ldots \ldots \ldots \ldots \ldots$

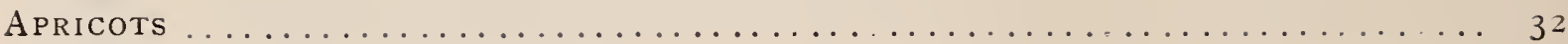

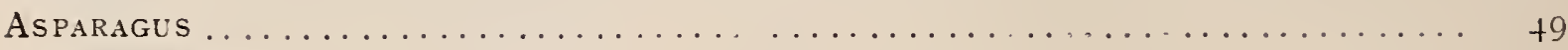

Blackberries ...................................... $\ldots$

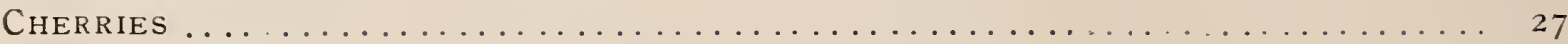

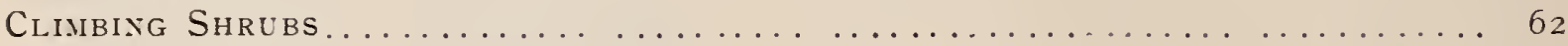

Crab Apples.................................... 6

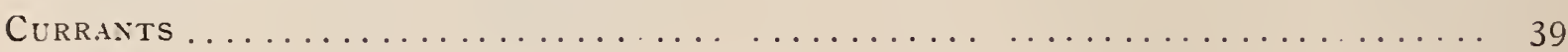

DaHLIAS . . . . . . . . . . . . . . . . . . . . . . . . . . 77

Deciduous Trees ... . . . . . . . . . . . . . . . . . . . . . 52

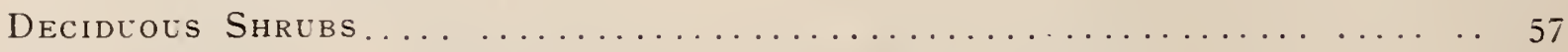

DEWBERRIES . . . . . . . . . . . . . . . . . . . . . . . . .

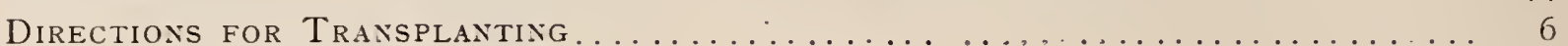

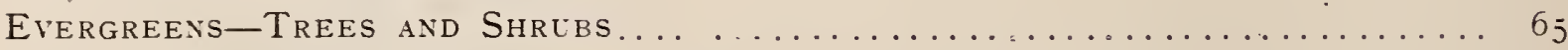

GLAdiolus ........................................ 78

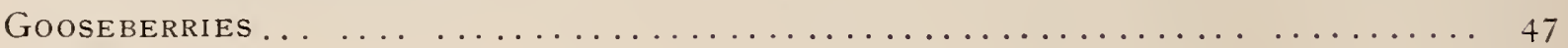

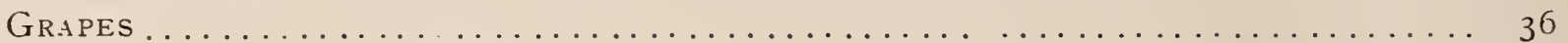

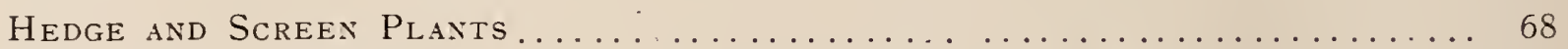

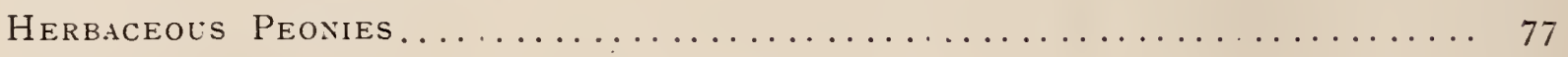

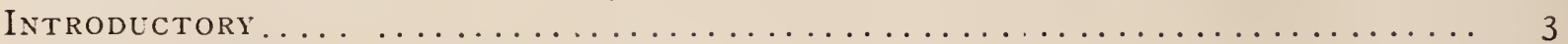

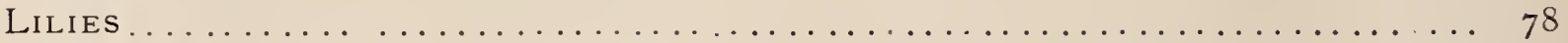

Miscellaneous Fruits and Nuts ......................... 5 I

Miscellaneous Flowering Bulbs ......................... 79

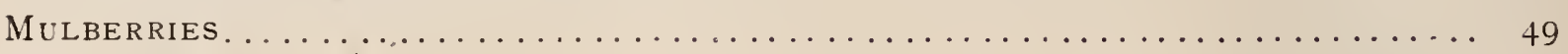

Nectarines . . . . . . . . . . . . . . . . . . . . . . . . . . . 33

PEACHES ...................................... 2 I

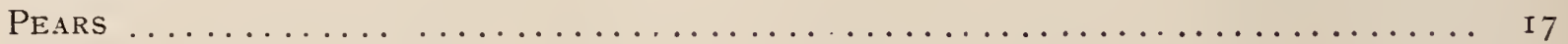

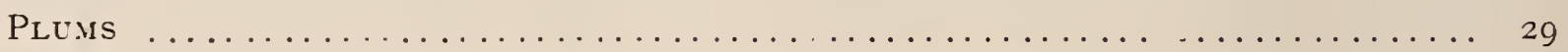

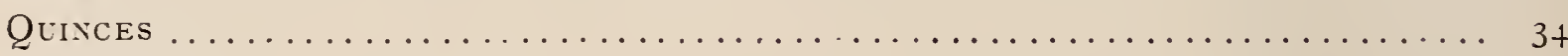

RASPBERRIES .................................. 4 I

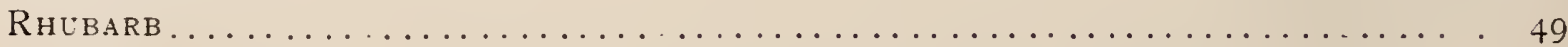

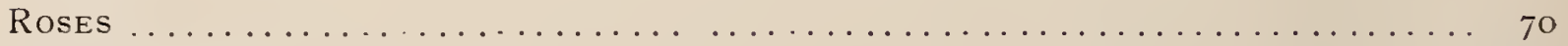

StrawberRies.................................... 45

To Correspondents .................................

Tree Peonies................................... 77

Tuberoses ............................................ 79

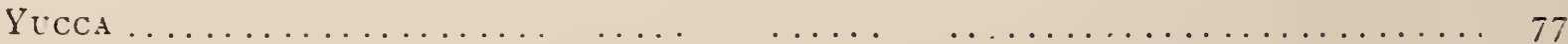




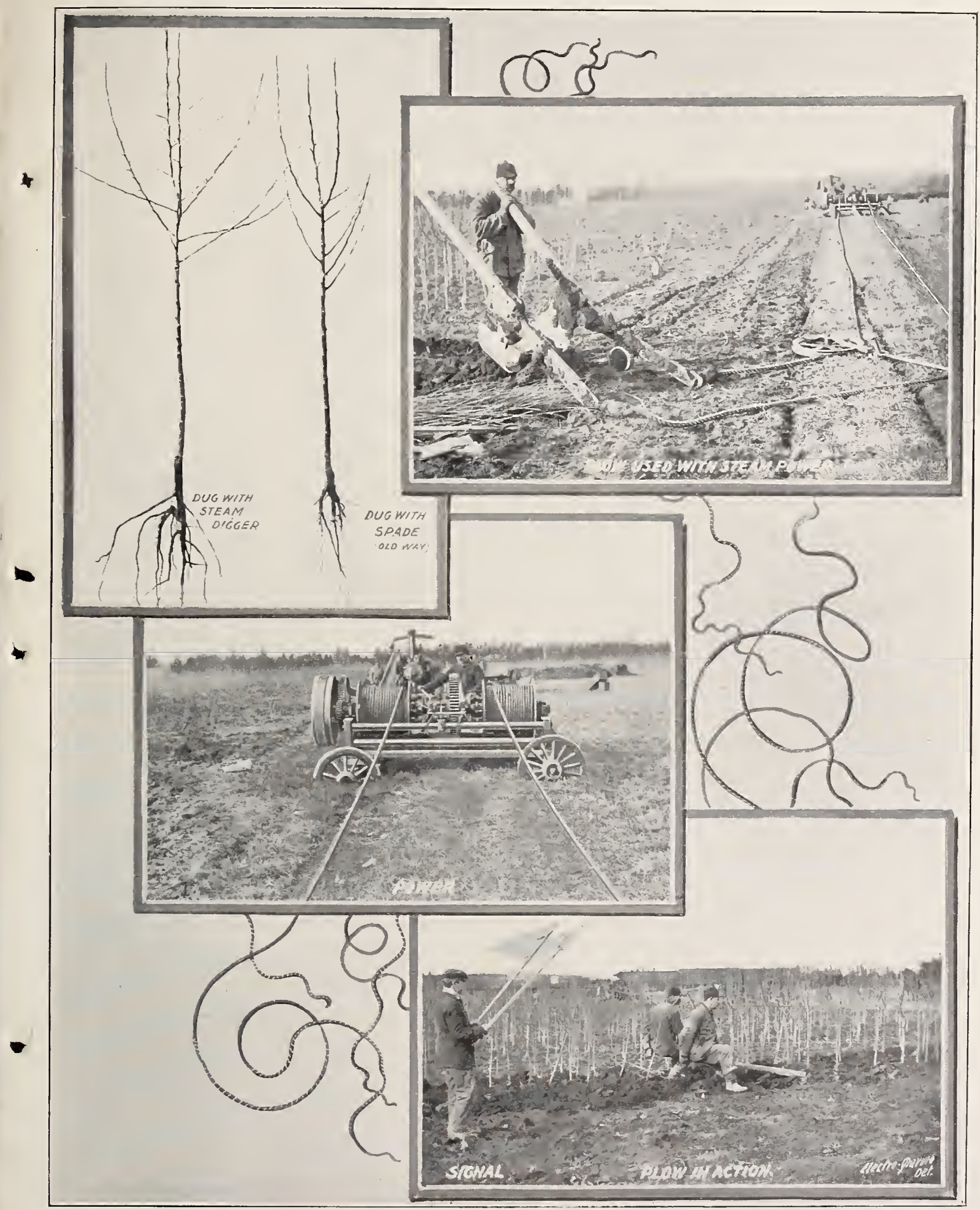

Views of Steam Tree Digger. A late invention of merit, successfully operated in our Nursery. 


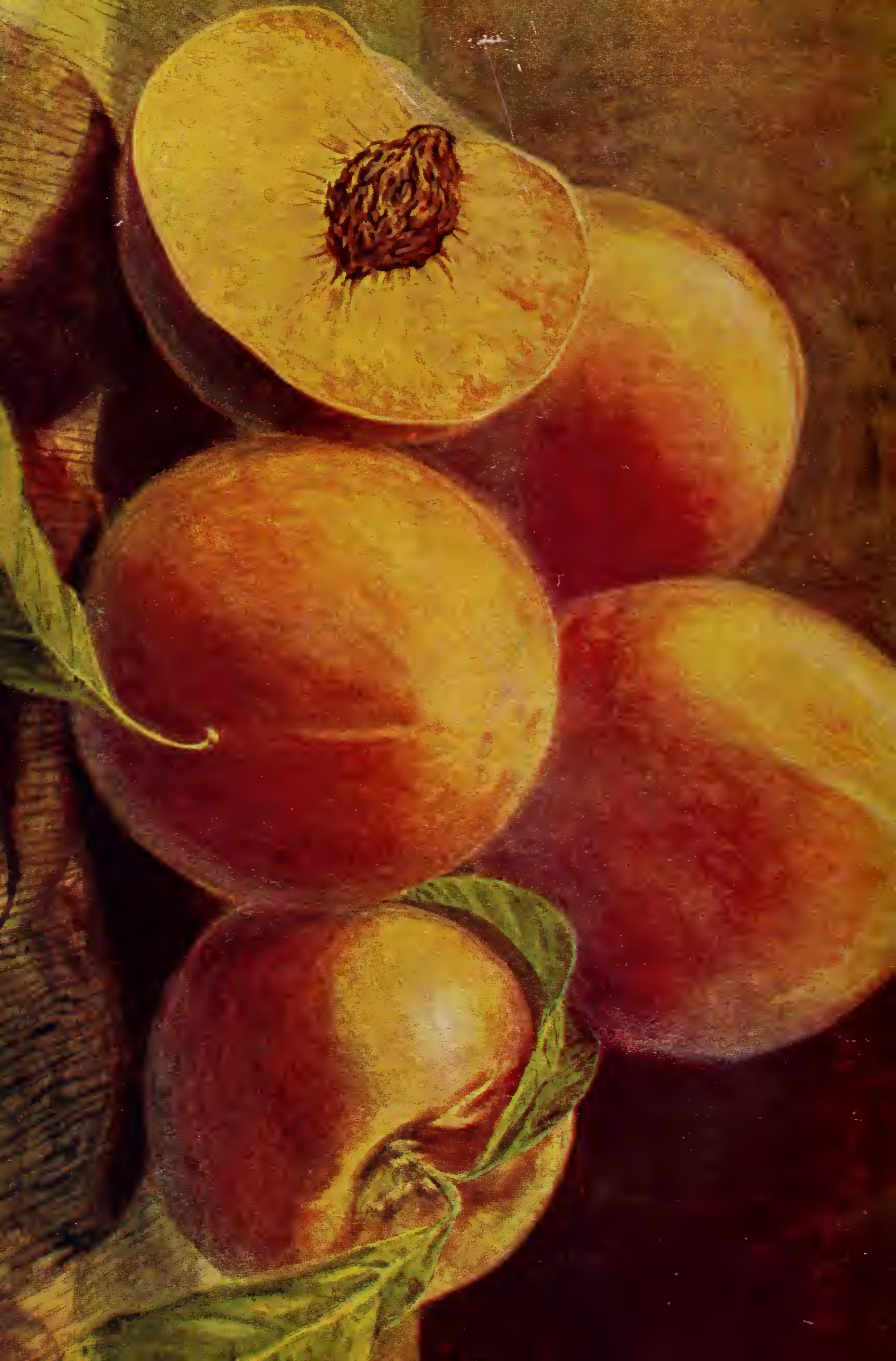

